UNIVERSIDADE DE BRASÍLIA - UnB

FACULDADE DE ECONOMIA, ADMINISTRAÇÃO, CONTABILIDADE E CIÊNCIA DA INFORMAÇÃO E DOCUMENTAÇÃO - FACE

DEPARTAMENTO DE CIÊNCIA DA INFORMAÇÃO E DOCUMENTAÇÃO - CID

MARIA ELIANA DE OLIVEIRA GONÇALO

ESTUDO DE SATISFAÇÃO DOS USUÁRIOS DA BIBLIOTECA DIGITAL JURÍDICA DO SUPERIOR TRIBUNAL DE JUSTIÇA 
MARIA ELIANA DE OLIVEIRA GONÇALO

ESTUDO DE SATISFAÇÃO DOS USUÁRIOS DA BIBLIOTECA DIGITAL JURÍDICA DO SUPERIOR TRIBUNAL DE JUSTIÇA

Monografia de Graduação apresentada ao Curso de Biblioteconomia do Departamento de Ciência da Informação e Documentação da Universidade de Brasília, como requisito para a obtenção do grau de Bacharel em Biblioteconomia.

Orientador: Prof. Dr. Murilo Bastos da Cunha. 


\section{ESTUDO DE SATISFAÇÃO DOS USUÁRIOS DA BIBLIOTECA DIGITAL JURÍDICA DO SUPERIOR TRIBUNAL DE JUSTIÇA}

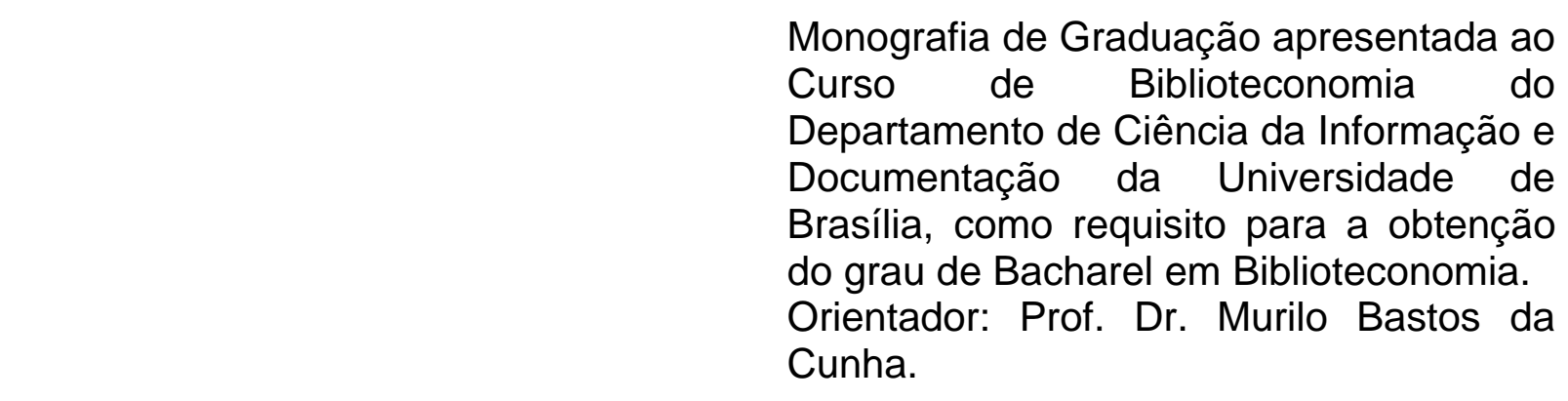

Aprovado em: / /

BANCA EXAMINADORA

Prof. Dr. Murilo Bastos da Cunha (Orientador)

Departamento de Ciência da Informação e Documentação da UnB

Prof. Dra. Dulce Maria Baptista

Coordenadora do Departamento de Ciência da Informação e Documentação da UnB (Examinador Interno)

Teresa Helena Moraes Marciano da Rocha Basevi

Coordenadora da BDJur/STJ (Examinador Externo) 
A meu pai (in memorian), e à minha mãe, pelo o amor dedicado e tudo que me ensinaram. 


\section{AGRADECIMENTOS}

A Deus, por tudo;

A minha família, sem a qual não teria chegado aqui, pelo o apoio, incentivo e amor; Ao professor Murilo Bastos da Cunha, pela orientação e tudo que me ensinou; À Teresa Basevi, Coordenadora da BDJur/STJ, pela a compreensão e ajuda; À Laila Dantas, chefe da BDJur/STJ, pelo o apoio, incentivo e colaboração; A Marco Keller, equipe de Informática, pela a ajuda na disponibilização do questionário na internet e intranet;

A Márcio Rodrigo, da Web, pela a ajuda com o Sistema de Pesquisa do STJ; A Fabiana Damasceno pela a revisão ortográfica;

À equipe de informática do Superior Tribunal de Justiça pelo o apoio técnico; Aos professores e funcionários do Departamento de Ciência da Informação e Documentação;

A todos que responderam ao questionário, por ter tornado possível esse trabalho; A todos os meus amigos e colegas de curso e de trabalho que de alguma forma me ajudaram. 
"O conhecimento é o processo de acumular dados;

a sabedoria reside na sua simplificação."

Martin H. Fischer 


\section{RESUMO}

O objetivo geral da pesquisa foi verificar o grau de satisfação dos usuários da Biblioteca Digital Jurídica do Superior Tribunal de Justiça (BDJur/STJ); os objetivos específicos foram: identificar o perfil dos usuários da BDJur; verificar o grau de satisfação dos usuários em relação aos serviços da BDJur; conhecer a opinião dos usuários da BDJur no que diz respeito ao acervo; e reunir dados que possam promover melhorias nas condições da BDJur. O universo da pesquisa foi composto por todos os usuários da BDJur e a coleta de dados foi feita por meio de um questionário, com 18 questões, disponibilizado na página da Intranet e Internet da BDJur. Ao total foram respondidos, tabulados e analisados 783 questionários. Os resultam mostram que, considerando os parâmetros "Bom" e "Excelente" como satisfatório, itens como: layout, interface e resultado de pesquisa e qualidade do conteúdo tiveram mais de $70 \%$ de aprovação por parte dos respondentes. Os usuários fizeram sugestões para melhorias na BDJur, como: a disponibilização de inteiro teor de documentos restritos; simplificação no processo de cadastramento; e inclusão de mais documentos de matéria jurídica. Conclui-se que $84 \%$ dos usuários estavam satisfeitos com a BDJur.

Palavras-chave: Biblioteca digital; Estudo de usuários; Superior Tribunal de Justiça; Biblioteca Digital Jurídica. 


\section{LISTA DE ILUSTRAÇÕES}

Figura 1. Evolução da biblioteca digital 


\section{LISTA DE GRÁFICOS}

Gráfico 1 - Grau de formação mais elevado

Gráfico 2 - Cargo

Gráfico 3 - Tempo que utiliza a BDJur $\quad 50$

Gráfico 4 - Coleções inscritas no serviço "Alerta por e-mail" 52

Gráfico 5 - Cruzamento dos usuários inscritos no serviço de "Alerta por 52 e-mail" com o grau de formação

Gráfico 6 - Contato com a BDJur 53

Gráfico 7 - Cruzamento do número de solicitações atendidas/não 54 atendidas com o cargo do usuário

Gráfico 8 - Satisfação com relação ao layout da BDJur 55

Gráfico 9 - Satisfação com relação à interface de pesquisa da BDJur 56

Gráfico 10 - Satisfação com relação à organização das coleções da 56 BDJur

Gráfico 11 - Satisfação com relação à qualidade do conteúdo da BDJur 57

Gráfico 12 - Cruzamento do cargo com a satisfação quanto à qualidade 58 do conteúdo da BDJur

Gráfico 13 - Satisfação com relação organização da ferramenta da 59 BDJur

Gráfico 14 - Satisfação com relação à clareza dos objetivos das 59 coleções da BDJur

Gráfico 15 - Cruzamento do cargo com a satisfação em relação à 60 clareza dos objetivos das coleções da BDJur

Gráfico 16 - Satisfação com relação resultado de pesquisa da BDJur

Gráfico 17 - Cruzamento do cargo com a satisfação em relação ao 62 resultado de pesquisa da BDJur

Gráfico 18 - Satisfação em relação à BDJur de uma maneira geral 63

Gráfico 19 - Cruzamento do cargo com a satisfação em relação à BDJur 
Gráfico 20 - Freqüência de uso da coleção "Acervo fotográfico"

Gráfico 21 - Freqüência de uso da coleção "Atos Normativos"

Gráfico 22 - Freqüência de uso da coleção "Coletânea de Julgados e 67 Momentos Jurídicos dos Magistrados no TFR e STJ"

Gráfico 23 - Freqüência de uso da coleção "Documentos sobre a BDJur 67 do STJ"

Gráfico 24 - Freqüência de uso da coleção "Documentos Administrativo 68 do STJ"

Gráfico 25 - Freqüência de uso da coleção "Documentos Jurídicos"

Gráfico 26 - Freqüência de uso da coleção "Escola Nacional de 70 Formação e Aperfeiçoamento de Magistrados - ENFAM"

Gráfico 27 - Freqüência de uso da coleção "Eventos do STJ"

Gráfico 28 - Freqüência de uso da coleção "Grupos de Pesquisa da 71 CAPES"

Gráfico 29 - Freqüência de uso da coleção "Jurisprudência do STJ"

Gráfico 30 - Freqüência de uso da coleção "Laboratório de Conservação

e Restauração de Documentos - LACOR"

Gráfico 31 - Freqüência de uso da coleção "Links Jurídicos"

Gráfico 32 - Freqüência de uso da coleção "Obras Raras"

Gráfico 33 - Freqüência de uso da coleção "Pesquisa Jurídica"

Gráfico 34 - Freqüência de uso da coleção "Produção Intelectual dos Ministros do STJ"

Gráfico 35 - Freqüência de uso da coleção "Sumários Jurídicos"

Gráfico 36 - Freqüência de uso da coleção "Tecnologia da BDJur"

Gráfico 37 - Freqüência de uso da coleção "Teses e Dissertações"

Gráfico 38 - Freqüência de uso da coleção "Trabalhos de Conclusões de 79 Curso e Monografias" 


\section{LISTA DE SIGLAS}

BDJur - Biblioteca Digital Jurídica

BSD - Berkeley Software Distribution

CBID - Coordenadoria da Biblioteca Digital

CDU - Classificação Decimal Universal

$\mathrm{Cl}$ - Ciência da Informação

HP - Hewlett-Packard

IBD - Interface de Biblioteca Digital

IHC - Interface Humano-Computador

MIT - Massachusetts Institute of Technology

PRODASEN - Centro de Informática e Processamento de Dados do Senado Federal

RVBI - Rede Virtual de Bibliotecas

SINDI - Seção de Informação Digital

SICON - Sistema de Informações do Congresso Nacional

STF - Supremo Tribunal Federal

STI - Secretaria de Tecnologia da Informação

STJ - Superior Tribunal de Justiça

TFR - Tribunal Federal de Recursos

UnB - Universidade de Brasília

WWW - World Wide Web 


\section{SUMÁRIO}

Resumo

Lista de ilustrações

Lista de gráficos

vi

Lista de siglas

vii

ix

1. INTRODUÇÃO

ERRO! INDICADOR NÃO DEFINIDO.

1.1 CONTEXTO DA PESQUISA ERRO! INDICADOR NÃO DEFINIDO.

1.1.1 Superior Tribunal de Justiça.

Erro! Indicador não definido.

1.1.2 Biblioteca Ministro Oscar Saraiva

Erro! Indicador não definido.

1.1.3 Biblioteca Digital Jurídica - BDJur ....

Erro! Indicador não definido.

1.1.4 Consórcio BDJur

Erro! Indicador não definido.

1.1.5 Acervo da BDJur

Erro! Indicador não definido.

1.1.6 Resultados e Benefícios

Erro! Indicador não definido.

1.2 Problema e JuStificativa ERro! INDICADOR NÃo DEFINIDO.

1.3 OBJETIVOS ERRO! INDICADOR NÃO DEFINIDO.

1.3.1 Objetivo geral.

Erro! Indicador não definido.

1.3.2 Objetivos específicos

Erro! Indicador não definido.

2. REVISÃO DE LITERATURA ERRO! INDICADOR NÃO DEFINIDO.

2.1 A eVoluÇão da BiblioteCa Digital

ERRO! INDICADOR NÃO DEFINIDO.

2.2 BIBLIOTECA DIGITAL NA ÁREA JURÍDICA ERRO! INDICADOR NÃO DEFINIDO.

2.3 DSPACE ERRO! INDICADOR NÃO DEFINIDO.

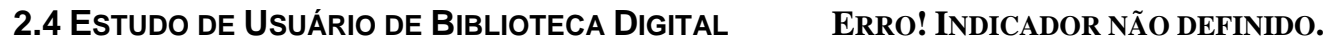

3. METODOLOGIA. ERRO! INDICADOR NÃO DEFINIDO.

3.1 UNIVERSO ERRO! INDICADOR NÃO DEFINIDO.

3.2 AMOSTRAERRO! INDICADOR NÃO DEFINIDO.

3.3 INSTRUMENTOS DE COLETA DE DADOS ERRO! INDICADOR NÃO DEFINIDO.

4. ANÁLISE E DISCUSSÃO DOS DADOS ................................ ERRO! INDICADOR NÃO DEFINIDO.

4.1 ANÁLISE DOS ITENS DO QUESTIONÁRIO APLICADO ERRO! INDICADOR NÃO DEFINIDO.

5. CONCLUSÃO................................................................... ERRO! INDICADOR NÃO DEFINIDO.

6. REFERÊNCIA BIBLIOGRÁFICA.......................................... ERRO! INDICADOR NÃO DEFINIDO.

ANEXOS............................................................................... ERRO! INDICADOR NÃO DEFINIDO. 


\section{INTRODUÇÃO}

A Biblioteca Digital Jurídica do Superior Tribunal de Justiça (BDJur/STJ) é o objeto de investigação desse trabalho que teve como objetivo verificar o grau de satisfação de seus usuários sob a perspectiva dos serviços disponibilizados. A falta de estudos de usuários em bibliotecas digitais tem levado a elaboração de padrões estabelecidos que muitas vezes vão de encontro com o imaginado pelo o usuário. Nas palavras de Silveira (2003), uma das limitações atuais para os usuários de bibliotecas digitais sem conhecimento em Interfaces Humano-Computador (IHCs), é que os sistemas disponibilizados têm sido desenvolvidos com base numa coleta de informações que não considera, no seu planejamento geral, os passos fundamentais, como a participação dos usuários e a identificação de suas necessidades.

Através da análise das respostas dadas e as sugestões apontadas pelos os próprios usuários da Biblioteca, foi possível verificar se a BDJur atende satisfatoriamente seus usuários e ainda, reunir informações que possam promover melhorias nas condições da BDJur/STJ.

A fim de alcançar os objetivos estabelecidos, a pesquisa teve caráter exploratório e foi realizada por meio de um estudo de caso, com a utilização de técnicas de investigação quantitativa por meio de um questionário.

Esta monografia possui a seguinte estrutura:

O capítulo 1 apresenta uma introdução, com a explicação do problema, justificativa e os objetivos.

O capítulo 2 contextualiza a pesquisa. 
O capítulo 3 trata da revisão de literatura, abordando tópicos pertinentes ao assunto.

O capítulo 4 descreve a metodologia utilizada na pesquisa.

O capítulo 5 apresenta a análise e discussão dos dados coletados.

O Capítulo 6 traz as conclusões, críticas e sugestões para futuros estudos.

Por fim, têm-se a lista de referência consultada e os anexos. 


\subsection{Problema e justificativa}

A pesquisa pretende responder a seguinte indagação: como as informações disponibilizadas na Biblioteca Digital atendem as necessidades de informação dos usuários da Biblioteca Digital Jurídica?

Os usuários de uma biblioteca digital, nesse caso uma biblioteca especializada em direito, necessitam de fontes de informação para pesquisa, ou seja, são público alvo de uma biblioteca especializada.

A opinião destes, e principalmente sua contribuição nos serviços de disseminação e recuperação da informação na biblioteca digital poderá enriquecer o trabalho e beneficiarão todos os segmentos da biblioteca quanto às necessidades de informação dos mesmos.

\subsection{Objetivos}

\subsubsection{Objetivo geral}

Verificar se as informações disponibilizadas na Biblioteca Digital atendem às necessidades de informação dos usuários da Biblioteca Digital do Superior Tribunal de Justiça.

\subsubsection{Objetivos específicos}

(OE1) Identificar o perfil dos usuários da Biblioteca Digital do Superior Tribunal de Justiça;

(OE2) Verificar o grau de satisfação dos usuários em relação aos serviços da Biblioteca Digital do Superior Tribunal de Justiça;

(OE3) Conhecer a opinião dos usuários da Biblioteca Digital do Superior Tribunal de Justiça no que diz respeito ao acervo da mesma; 
(OE4) Reunir informações que possam promover melhorias nas condições da Biblioteca Digital do Superior Tribunal de Justiça. 


\section{Contexto da pesquisa}

\subsection{Superior Tribunal de Justiça}

O Superior Tribunal de Justiça (STJ), instituído pela Constituição de 1988, foi instalado em 7 de abril de 1989 (Lei no 7.746/89), atuando como tutor da inteireza positiva, da autoridade e da uniformidade interpretativa da lei federal e como destacado guardião das liberdades.

A sua missão é processar e julgar as matérias de sua competência originária e recursal, assegurando a uniformidade na interpretação das normas infraconstitucionais e oferecendo ao jurisdicionado uma prestação acessível, rápida e efetiva.

O STJ é a última instância da Justiça brasileira para as causas infraconstitucionais, não relacionadas diretamente à Constituição. Como órgão de convergência da Justiça comum, aprecia causas oriundas de todo o território nacional, em todas as vertentes jurisdicionais não-especializadas.

Sua competência está prevista no art. 105 da Constituição Federal, que estabelece os processos que têm início no STJ (originários) e os casos em que o Tribunal age como órgão de revisão, inclusive nos julgamentos de recursos especiais.

O STJ julga crimes comuns praticados por governadores dos estados e do Distrito Federal, crimes comuns e de responsabilidade de desembargadores dos tribunais de justiça e de conselheiros dos tribunais de contas estaduais, dos membros dos tribunais regionais federais, eleitorais e do Trabalho.

Julga também habeas-corpus que envolvam essas autoridades ou ministros de Estado, exceto em casos relativos à Justiça Eleitoral. Pode apreciar ainda recursos contra habeas-corpus concedidos ou negados por tribunais regionais 
federais ou dos estados, bem como causas decididas nessas instâncias, sempre que envolverem lei federal.

Em 2005, como parte da reforma do Judiciário, o STJ assumiu também a competência para analisar a concessão de cartas rogatórias e processar e julgar a homologação de sentenças estrangeiras. Até então, a apreciação desses pedidos era feita no Supremo Tribunal Federal (STF).

O Superior Tribunal de Justiça compõe-se de, no mínimo, 33 Ministros, escolhidos entre brasileiros com mais de trinta e cinco e menos de sessenta e cinco anos, de notável saber jurídico e reputação ilibada, conforme determina o art. 104 da Constituição Federal, originários de todas as classes de profissionais do Direito ligados à administração da Justiça: magistrados federais e estaduais, advogados e membros do Ministério Público Federal, Estadual e do Distrito Federal e dos Territórios. Nomeados pelo Presidente da República depois de aprovada a indicação pelo Senado Federal, são eleitos previamente em Sessão Plenária, mediante lista tríplice, para cuja elaboração observa-se o seguinte critério:

- um terço das vagas é preenchido por juízes dos Tribunais Regionais Federais;

- um terço, por desembargadores dos Tribunais de Justiça;

- um terço é reservado, em partes iguais, a advogados e membros do Ministério Público Federal, Estadual e do Distrito Federal e dos Territórios, alternadamente, desde que tenham mais de dez anos de efetiva atividade profissional e sejam indicados, em lista sêxtupla, pelos seus órgãos de representação. 
Para sua composição inicial, a Constituição de 1988, no art. 27 , § 2º do Ato das Disposições Transitórias, determinou o aproveitamento dos Ministros que integravam o antigo Tribunal Federal de Recursos.

\subsection{Biblioteca Ministro Oscar Saraiva}

A Biblioteca foi criada em 28 de junho de 1948 para atender aos Ministros do Tribunal Federal de Recursos (TFR), sediado no Rio de Janeiro. Presidia o Tribunal, na época, o Ministro Afrânio Antônio da Costa.

Em 1960, o TFR foi instalado em Brasília, mas a Biblioteca permaneceu no Rio de Janeiro, sendo somente transferida para a nova capital em 1969.

Já transferida em 1969, a Biblioteca encontrava-se no $3^{\circ}$ andar do prédio próprio do Tribunal em Brasília.

O ano de 1970 representou o marco inicial para o desenvolvimento da Biblioteca, quando se iniciou o processamento e a organização do acervo bibliográfico.

Em 15 de junho de 1973, atribuíram-lhe o nome de "Biblioteca Ministro Oscar Saraiva", a fim de homenagear o Ministro responsável pela construção do edifício sede do TFR.

A Biblioteca encontra-se registrada no Conselho Regional de Biblioteconomia - $1^{\text {a }}$ Região sob o número 04, e tal registro foi efetivado em 29 de janeiro de 1977.

Com a extinção do TFR e a instalação do STJ em 1989, a Biblioteca iniciou a automação do seu acervo bibliográfico, por meio do Sistema de Informações do Congresso Nacional (SICON), mantido pelo PRODASEN (Centro de Informática e Processamento de Dados do Senado Federal). A partir de então, a Biblioteca tomou 
um grande impulso, devido aos novos recursos de que pôde dispor, bem como pelo desenvolvimento de novas atividades.

Em julho de 1995, sob a presidência do Ministro Bueno de Souza, a Biblioteca transferiu-se para a atual sede do STJ, onde ganhou modernas e amplas instalações, possibilitando uma crescente atualização do acervo bibliográfico, assim como o desenvolvimento de novos serviços, mantendo a qualidade de atendimento aos usuários internos e externos.

À Biblioteca Ministro Oscar Saraiva compete desenvolver as atividades relacionadas ao acervo bibliográfico, visando subsidiar o atendimento às solicitações de informações jurídicas e de análise e tratamento da informação, bem como promover ações com vistas ao planejamento da Secretaria, e dessa forma:

I - adotar medidas de utilização e de segurança dos documentos sob sua guarda;

II - promover o intercâmbio com instituições afins;

III - participar de redes cooperativas de informação;

IV - propor e gerir a aquisição de livros no âmbito do STJ e demais materiais bibliográficos para o seu acervo;

V - providenciar a divulgação de publicações (Regulamento dos Serviços da Secretaria de Documentação).

- Acervo Bibliográfico

A Biblioteca Ministro Oscar Saraiva é composta de livros, periódicos, obras de referência, folhetos, teses, separatas e documentos em meio eletrônico. É essencialmente voltada para a área jurídica, dando ênfase a todos os ramos da Ciência do Direito.

Em agosto de 2006, o acervo era composto de: 
o 62.285 obras em geral, sendo: 57.141 livros, 1.904 folhetos, 1.667 obras raras e 305 teses;

o 1.812 documentos eletrônicos (vídeos, CDs, disquetes, DVD);

o 555 títulos de periódicos, sendo: 525 títulos nacionais e 30 títulos estrangeiros; 49 títulos de periódicos em meio eletrônico; 82.794 fascículos de periódicos e 10.612 artigos indexados;

o 14.909 Legislação tratada, sendo: 978 clipping de legislação, 1.590 Sistema de Atos Normativos do TFR e 12.341 Sistema de Atos Oficiais;

o Coleção completa dos Diários da Justiça, Seção I, desde 1948;

o Coleção do Diário Oficial da União e Diário da Justiça em CD-ROM, a partir de 2003.

Tem como finalidade precípua subsidiar a demanda de informações provenientes dos Gabinetes dos Ministros. Destina-se também ao uso dos servidores do Superior Tribunal de Justiça e aos usuários externos.

Encontra-se disponível, via Intranet e Internet, a home-page da Biblioteca que permite ao usuário a obtenção de informações sobre os seus produtos e serviços.

O acervo bibliográfico é aberto a todos os consulentes e encontra-se automatizado por meio da Rede Virtual de Bibliotecas (RVBI), mantida pelo PRODASEN.

$\mathrm{Na}$ organização do seu material bibliográfico adota-se o Sistema de Classificação Decimal Universal (CDU).

Dispõe também de sistema de código de barras que viabiliza de forma ágil e eficaz o empréstimo das obras (livros e coleções especiais). 
É protegida por um sistema de segurança que, por meio de um sensor magnético adaptado aos livros, acusa na saída, quando estes são retirados do acervo sem efetivação do empréstimo.

No hall de entrada encontra-se um mostruário com as publicações editadas pela Secretaria de Documentação, os livros e periódicos recém adquiridos, folhetos informativos de eventos, bem como jornais de circulação nacional e os Diários Oficiais da União e da Justiça disponíveis, diariamente, para consulta. Também estão disponibilizados três terminais de computador para o usuário acessar ao catálogo local e informações gerais.

Dispõe de uma sala especial, climatizada, que reúne cerca de 1.667 volumes de obras raras, as quais estão disponíveis somente para consulta.

Em razão do seu livre acesso, não é permitida a entrada de usuários portando bolsas, pastas e/ou materiais similares que deverão ser depositados em local apropriado, na recepção, bem como a utilização de aparelhos celulares.

Os usuários devem deixar o material bibliográfico consultado sobre as mesas e prateleiras, onde os servidores se encarregarão de recolocá-lo nos devidos lugares.

É vedado o consumo de alimentos e bebidas nas áreas de estudo e acervo, tendo em vista a preservação do material bibliográfico.

\section{- Aquisição}

A solicitação de aquisição do material bibliográfico é feita pela Diretora da Divisão de Doutrina e Legislação, que seleciona os livros mediante análise dos catálogos enviados pelas editoras e sugestões dos Ministros, e demais servidores desta Egrégia Corte. 
Os usuários podem sugerir a aquisição de publicações, preenchendo o Formulário de Sugestões, disponível na Seção de Atendimento ao Usuário e na Intranet.

\section{- Serviços oferecidos}

A Biblioteca é formada por uma equipe de profissionais capacitados para orientar o leitor em suas consultas. O usuário pode consultar o catálogo da Biblioteca acessando a Rede Virtual de Bibliotecas (RVBI), via Intranet/Internet ou solicitar que um profissional realize a consulta.

Os usuários de todas as Unidades da Federação podem obter, via e-mail e fax, respostas às solicitações de pesquisas e informações doutrinárias e legislativas sobre os mais variados ramos do Direito.

Os pedidos de livros, periódicos e legislação são efetivados através da Seção de Atendimento ao Usuário que providencia o material solicitado, disponibilizando-o ao usuário.

\section{Fornecimento de Cópias}

O usuário pode solicitar cópias de artigos de periódicos, de verbetes de obras de referência, de capítulos de livros, de legislação e de jornais.

As cópias reprográficas são fornecidas, por meio da Seção de Circulação, internamente, através de preenchimento de formulário próprio devidamente assinado e carimbado e, externamente, através do recolhimento de uma taxa de acordo com a quantidade de cópias solicitadas.

O servidor inativo será atendido mediante o preenchimento de formulário específico assinado pela Associação dos Servidores Aposentados do Poder Judiciário. 
Devem ser observados os seguintes horários para o fornecimento de cópias reprográficas:

Usuário Interno - de 9 às 19 horas

Usuário Externo - de 12 às 18 horas (pagamento efetuado na Subsecretaria de Orçamento e Finanças); e de 09 às 19 horas (pagamento efetuado via internet Banco do Brasil).

Os pedidos de cópias por instituições diversas são atendidos mediante o encaminhamento de um ofício, por meio de suas bibliotecas respectivas.

\section{Empréstimo e Reserva de Publicações Impressas e em Meio Eletrônico}

A Biblioteca Ministro Oscar Saraiva implantou em janeiro de 2000 um novo serviço automatizado de empréstimo de publicações, utilizando o módulo de circulação ALEPH.

Para a efetivação do empréstimo e reserva de publicações, a Biblioteca procede conforme o disposto na OS no 04, de 08/08/2003. O empréstimo destina-se aos Ministros do Tribunal, servidores do quadro de pessoal, ativos, inativos, requisitados e ocupantes de cargos em comissão e funções comissionadas, bem como a outras instituições por meio do intercâmbio entre bibliotecas.

As solicitações de publicações pertinentes ao acervo das bibliotecas, no âmbito do Distrito Federal são realizadas para atender somente aos Ministros. Aos demais servidores é providenciado cópias de doutrina e legislação.

Não é permitido o empréstimo de publicações aos servidores afastados, por motivos elencados nos artigos 84, 91, 92, 93, 94, 95 e 96 da Lei 8.112/90. Os Ministros aposentados realizam o empréstimo através da Assessoria de Apoio aos Ministros Aposentados. 
O empréstimo é efetuado na Seção de Atendimento ao Usuário, não sendo permitido para as obras raras, de referência e periódicos impressos.

Para a realização do empréstimo, os usuários internos devem estar previamente cadastrados no Sistema e firmar um "Termo de Compromisso" com a Biblioteca.

\section{Pesquisas}

A Seção de Pesquisa realiza pesquisas exaustivas de doutrina e legislação nos diversos bancos de dados da RVBI, SICON, do Sistema de Legislação da Biblioteca e em outras redes nacionais de informação.

Por meio do serviço "Pesquisa Virtual", disponível na Intranet e Internet, o usuário interno e externo pode obter orientações para solicitar pesquisas de doutrina e legislação por e-mail, como também pessoalmente ou por telefone.

A Biblioteca integra, alimenta e acessa dados de seu acervo e de outras bibliotecas participantes da RVBI, recuperando informações contidas, principalmente, nos seguintes bancos de dados:

Livros e analíticas - disponibilizam informações sobre livros, capítulos de livros, folhetos, teses e obras raras de todas as bibliotecas participantes da Rede. Possibilitam a recuperação de dados por autor, título, assunto e quaisquer outros campos previamente alimentados.

Periódicos - disponibiliza informações sobre os artigos e títulos de periódicos e sua coleção. Recupera as informações através do título de periódico, autor, título e assunto do artigo e quaisquer outros campos previamente alimentados. 


\section{Sistema de Informações do Congresso Nacional (SICON)}

NJUR - Normas Jurídicas - disponibiliza pela Internet as normas jurídicas, editadas no País, desde 1946, até o nível de Decreto. Acessa ainda outras bases de dados legislativas.

\section{Sistema de Atos Normativos do Tribunal Federal de Recursos - TFR}

Possibilita a recuperação das normas jurídicas emanadas pelo extinto Tribunal Federal de Recursos, desde sua criação (exceto normas de pessoal).

\section{Sistema de Atos Oficiais (Sistema de Legislação)}

- Atos Normativos

Permite a recuperação das normas jurídicas emanadas do STJ, desde a sua criação (exceto normas de pessoal). O sistema disponibiliza informações dos Tribunais, Conselho da Justiça Federal e atos do Poder Executivo de possível interesse para o usuário, via Intranet/Internet. Disponibiliza ainda os atos normativos do STJ em inteiro teor.

\section{Publicações Impressas (divulgação interna e externa)}

- Atos Normativos do STJ

Atualizado anualmente, relaciona todas as normas jurídicas, em inteiro teor, emanadas do Superior Tribunal de Justiça, com exceção dos atos de pessoal. Possui índice de assunto que remete à norma relacionada na publicação.

- Atos Normativos do TFR

Coletânea histórica, publicada em 5 volumes, com as referências dos atos normativos (exceto normas de pessoal), emanados pelo extinto Tribunal Federal de Recursos, no período de março de 1948 a abril de 1989. 


\section{- Bibliografia Especializada}

Editada anualmente, reúne referências de livros e artigos de periódicos sobre determinado assunto da área jurídica. Possui índices de autor, título e assunto.

- Boletim da Biblioteca

Divulga, anualmente, o acervo bibliográfico contido nos Bancos de Dados da RVBI, ou seja, os livros, capítulos de livros, materiais e coleções especiais que compõem o acervo bibliográfico e os artigos de periódicos indexados pela Biblioteca. Traz índices de autor, título e assunto.

- Direito e Justiça

Editado anualmente, referencia os artigos publicados semanalmente no Caderno "Direito e Justiça" do Correio Braziliense. As informações contidas nesta publicação são recuperadas através da base de dados de jornais da RVBI.

- Informativo Jurídico da Biblioteca Ministro Oscar Saraiva

Periódico que vem sendo editado, semestralmente, desde 1989, publica artigos jurídicos dos Ministros do STJ, relaciona as novas publicações adquiridas e compila bibliografias específicas sobre diversos temas da área jurídica. Dispõe de índice de assuntos que remete à referência bibliográfica das novas aquisições.

\section{Publicações Eletrônicas}

- Artigos Jurídicos

Divulga o sumário do último número recebido de revistas jurídicas selecionadas pela Biblioteca.

- Clipping de legislação

É editado diariamente e tem por finalidade a divulgação corrente do texto integral dos principais atos normativos emanados do Superior Tribunal de Justiça, 
Conselho da Justiça Federal e demais Tribunais, assim como da legislação dos Poderes Executivo e Legislativo.

- Novas Aquisições

Divulga diariamente, por meio de resenhas, seleção de novos livros adquiridos por compra e doação, incorporados ao acervo da Biblioteca.

\section{Serviços Eletrônicos}

- Catálogo da Biblioteca

Pesquisa nas bases de dados da Rede Virtual de Bibliotecas (RVBI).

- Conheça a Biblioteca

Folder informativo sobre a Biblioteca, seus produtos e serviços.

- Diário Oficial da União e Diário da Justiça

Divulgação do texto integral dos Diários Oficial da União e da Justiça, publicados eletronicamente pela Imprensa Nacional.

- Informações Jurídicas ao Alcance do seu Mouse

Guia de portais e sites jurídicos para consulta e pesquisa.

- Pesquisa Virtual

Orientações para solicitar pesquisas de doutrina e/ou legislação por e-mail.

- Sugestão para compra de livros

Formulário colocado à disposição dos usuários internos para indicação de livros a serem incorporados à coleção da Biblioteca.

\subsection{Biblioteca Digital Jurídica - BDJur}

Período de implantação da BDJur: maio de 2004 a novembro de 2004 estruturação e desenvolvimento da BDJur; dezembro de 2004: disponibilização da BDJur na Intranet do STJ e internet. 
Os seus objetivos são:

- Criar bibliotecas digitais no Poder Judiciário;

- Disponibilizar conteúdos jurídicos de interesse para o Poder Judiciário na internet;

- Facilitar o processo de gestão do conhecimento no Poder Judiciário;

- Contribuir para a democratização e a acessibilidade da informação jurídica, comungando com a política de livre acesso ao conhecimento;

- Criação de um único portal de pesquisa que integre as bibliotecas digitais dos órgãos do Poder Judiciário, essenciais e auxiliares da Justiça;

- Disponibilizar para a sociedade o conhecimento jurídico em uma única plataforma, de forma gratuita e em inteiro teor.

A BDJur/STJ é uma iniciativa de acesso livre à informação. Integra o Consórcio BDJur, uma rede de bibliotecas digitais formada pelo Poder Judiciário e órgãos essenciais e auxiliares da Justiça. Sua missão é prover o acesso gratuito a informações jurídicas de interesse à sociedade, em formato digital e inteiro teor. No repositório é possível encontrar doutrina, legislação e jurisprudência, assim como palestras, discursos, teses e outros materiais pertinentes à atividade judicante.

As coleções estão organizadas por assunto, autor e título facilitando a recuperação das informações desejadas pelos usuários.

A BDJur/STJ é o primeiro repositório não acadêmico no mundo que utiliza o software Dspace. 


\subsection{Consórcio BDJur}

O Consórcio BDJur é uma rede de bibliotecas digitais formada pelos órgãos do Poder Judiciário, englobando as esferas federal e estadual, além dos órgãos essenciais e auxiliares da Justiça. Este instrumento pretende integrar, em um único portal, os mais importantes repositórios de informação digital jurídica do Judiciário, de forma a permitir consultas unificadas nesses acervos e possibilitar respostas instantâneas.

No Superior Tribunal de Justiça o Consórcio BDJur foi aprovado pelo então Presidente, Ministro Edson Vidigal, através do Ato $n^{\circ} 278$, de 22/09/2004, como projeto estratégico a ser implementado pelo Tribunal no contexto do Programa de Modernização do Sistema Judiciário.

A proposta do projeto era a transferência de tecnologia do STJ para a criação de bibliotecas digitais nos órgãos interessados em aderir ao Consórcio BDJur. Uma vez criadas, as diversas BDJur's terão seus metadados rastreados pelo harvester desenvolvido pelo Public Knowledge Project, possibilitando a interoperabilidade entre todos os repositórios.

Assim, o objetivo do Consórcio BDJur é colaborar com a disseminação dos documentos jurídicos eletrônicos de interesse para o Superior Tribunal de Justiça e demais órgãos do Poder Judiciário, contribuindo para a democratização e acessibilidade da informação jurídica, comungando com a política de livre acesso ao conhecimento.

\subsection{Acervo da BDJur}

O acervo da BDJur é formado por documentos digitais e/ou digitalizados, tais como: 
- partes de documentos pertencentes à Biblioteca Ministro Oscar Saraiva que foram digitalizados especificamente para serem integrados às coleções da BDJur;

- documentos produzidos originalmente em formato eletrônico (CDROM, DVD, Arquivos de texto, Fotografias, arquivos de áudio e/ou vídeo, etc.);

- URLs (sites), entre outros.

Esses acervos englobam doutrina, legislação, jurisprudência, palestras, cursos e outros materiais de interesse institucional e pertinentes às atividades do Poder Judiciário.

A publicação e divulgação dos documentos eletrônicos estão sempre respaldadas na legislação autoral vigente, respeitando todos os direitos dela decorrente.

A seguir são descritas algumas das coleções que integram a BDJur da Comunidade STJ (BDJur/STJ), primeiro repositório a integrar o Consórcio.

I - Coleção Documentos Jurídicos - Doutrina produzida por diversos juristas que autorizam a publicação de suas obras na BDJur. A Coleção também disponibiliza alguns artigos publicados no Jus Navigandi, fruto de uma parceria estabelecida entre as partes. A página inicial da Coleção esclarece que os conteúdos nela depositados são de inteira responsabilidade de seus autores e não expressam a opinião dos membros do STJ.

II - Coleção Links Jurídicos - Análise dos sites dos órgãos do Poder Judiciário. Onde está disponível a descrição dos principais produtos e serviços oferecidos nas páginas URL dos órgãos. 
III - Coleção Produção Intelectual dos Ministros do STJ - Contempla os documentos produzidos pelos Ministros do STJ. Divulga doutrina com entendimentos acerca de variados temas, assim como proporciona o acesso a discursos e palestras por eles proferidas, além de tornar públicos documentos inéditos e que não seriam submetidos aos modelos tradicionais de publicação impressa. Tal serviço visa à disseminação e preservação da produção intelectual institucional.

\section{IV - Documentação sobre a BDJur do STJ}

Manuais de alimentação, políticas, apresentações e outros documentos que norteiam o trabalho da Seção de Informação Digital e que podem orientar a criação de outras BDJurs.

V - Coleção Atos Normativos do STJ - A Coleção é uma seleção dos atos oficiais administrativos produzidos pelo Superior Tribunal de Justiça que são considerados de amplo interesse, não só para os membros do STJ mas também membros de outros órgãos do Poder Judiciário, bem como para a sociedade em geral.

VI - Coleção Teses e Dissertações - Disponibiliza teses e dissertações na área do Direito defendidas nas mais conceituadas Instituições de Ensino Superior do país.

VII - Coleção Pesquisas Jurídicas - Divulga uma seleção de resultados de pesquisas doutrinárias realizadas pela Seção de Pesquisa da Biblioteca Ministro Oscar Saraiva/STJ. O usuário não tem acesso ao teor dos documentos encontrados nas pesquisas. Única coleção da BDJur de acesso restrito por respeito aos direitos autorais. 
VIII - Tecnologia da BDJur - Versões e extensões do programa utilizado pela BDJur, criadas com o objetivo de customizar o software às necessidades particulares das coleções da BDJur do STJ.

IX - Trabalhos de Conclusão de Curso e Monografias - Trabalhos apresentados como requisitos para obtenção do grau de Bacharel em Direito e monografias apresentadas para conclusão de cursos de Pós-Graduação em Direito, em Instituições de Ensino Superior brasileiras.

\subsection{Resultados e Benefícios}

Os principais benefícios prescritos pela o Consórcio BDJur são:

- Acesso remoto pelos usuários (Ministros, advogados, servidores do Poder Judiciário e órgãos auxiliares, operadores do Direito, juristas, entre outros, poderão obter acesso à informação aonde quer que eles estejam, não havendo necessidade de se deslocar à biblioteca ou outra unidade para obter a informação);

- Possibilidade do Ministro do STJ acessar, em qualquer lugar, a qualquer tempo, a sua produção bibliográfica, e outra informação de seu interesse (através do Repositório Institucional - Coleção da Comunidade STJ);

- Descentralização das informações armazenadas pelo Consórcio cada Comunidade armazena o seu documento primário em seu banco de dados;

- Trabalho cooperativo entre os órgãos do Poder Judiciário; 
- Serviço, em sua essência, gratuito para os usuários. Alguns documentos poderão ter os seus acessos restritos, decorrente dos Direitos Autorais envolvidos;

- Padronização da linguagem de alimentação e recuperação da informação na legislação, doutrina e jurisprudência, através de um Tesauro único;

- Buscas e consultas simultâneas a diversos acervos digitais decorrentes do Protocolo OAI que possibilita a coleta dos metadados em diversos repositórios digitais;

- Resposta instantânea das demandas informacionais;

- Utilização simultânea do mesmo documento por diversas pessoas (não é mono-usuário);

- Inclusão de diversos produtos e serviços eletrônicos da própria Instituição (integrando e unificando o que cada unidade realiza);

- Existência de coleções de documentos correntes onde se pode acessar não somente a referência bibliográfica, mas também o seu texto completo;

- Utilização de diversos suportes de registro da informação e diversos formatos de documentos;

- Interoperabilidade entre os módulos da BDJur (possibilidade de comunicação entre os diversos sistemas e acervos que compõem a biblioteca digital) 


\section{REVISÃO DE LITERATURA}

O objetivo desta revisão de literatura é analisar as publicações associadas à usabilidade de bibliotecas digitais. Para a realização dessa revisão foram pesquisados: periódicos, livros, anais de conferência, teses e dissertações.

A revisão aborda os seguintes pontos: a evolução da biblioteca digital no Brasil; a biblioteca digital na área jurídica; o DSpace e o estudo de usuário de biblioteca digital.

\subsection{A evolução da Biblioteca Digital}

Antes de traçar um histórico da evolução da biblioteca digital, é importante apresentar o seu conceito de acordo com alguns autores.

Procópio (2004) define biblioteca digital como um:

\footnotetext{
Website que dispõe de uma coleção pública ou privada de livros, documentos eletrônicos ou congêneres, organizada para estudo, leitura e consulta. Organizadas por estantes virtuais [em ordem de autor, gênero ou obra] e que guardam e/ou ordenam arquivos de documentos eletrônicos, onde os leitores de todo o mundo acessam e fazem download a partir de um único servidor ou de vários servidores interligados.
}

Ainda segundo Procópio uma biblioteca digital abarca, além de livros, todas as demais formas de expressão escrita. Esta abrangência também propicia que os usuários do website tomem contato com a amplitude das questões que envolvem a comunicação escrita. Assim, o acervo propiciará uma interatividade, que não era possível nas bibliotecas tradicionais, através da comunidade que se formará em torno dele. 
O autor traz uma definição do que venha ser biblioteca digital, abordando a sua forma de organização "em ordem de autor, gênero ou obra" (que nem sempre se restringe e aparece dessa forma), o tipo de suporte dos documentos e até a maneira como os usuários terão acesso a essas informações armazenadas eletronicamente.

Um outro autor comenta, dentro do contexto digital, o conceito de biblioteca digital e como essa está se consolidando:

Mas biblioteca digital parece estar se firmando como a expressão que significaria, no contexto digital, um conjunto de artefatos, conhecimento, práticas e uma comunidade, que engendra compromissos realísticos assumidos por profissionais da informação, analistas de sistemas e usuários. (DIAS, 2001)

De acordo com Cunha (2000), "bibliotecas digitais são simplesmente um conjunto de mecanismos eletrônicos que facilitam a localização da demanda informacional, interligando recursos e usuários". Em um conceito mais condensado, porém não menos completo, este autor define bibliotecas digitais enfatizando o meio digital onde as informações estão armazenadas e a facilidade do usuário final em conseguir essas informações. Para ele o paradigma da biblioteca digital é diferente da tradicional por não existir um espaço físico.

Marchiori conceitua biblioteca digital deixando claro sua diferença entre a biblioteca tradicional:

A biblioteca digital difere das demais, porque a informação que ela contém existe apenas na forma digital, podendo residir em meios diferentes de armazenagem, como as memórias eletrônicas (discos magnéticos e óticos). Desta forma, a biblioteca digital não contém livros na forma convencional e a informação pode ser acessada, em locais específicos e remotamente, por meio de redes de computadores. (MARCHIORI, 1997) 
Já para Gladney (1994) a biblioteca digital vem a ser a complementação da biblioteca tradicional, seria uma extensão dos serviços oferecidos pela a biblioteca convencional. Em uma tradução de Alencar:

\begin{abstract}
Uma Biblioteca Digital é um conjunto de computação, armazenamento, e maquinaria de comunicações digitais juntamente com conteúdo e software necessários para reproduzir, emular, e estender os serviços fornecidos pelas bibliotecas convencionais com base em papeis e outros meios materiais para reunir, catalogar, buscar, e disseminar informações. Um serviço completo de biblioteca digital deve realizar todos os serviços essenciais das bibliotecas tradicionais, e também explorar as conhecidas vantagens do armazenamento, busca, e comunicação digitais. (GLADNEY, 1994 apud ALENCAR, p. 3, 2004).
\end{abstract}

E finalmente para Lesk (1997) o conceito de biblioteca digital vem a ser exatamente a sua combinação com a tradicional biblioteca:

"Coleções organizadas de informações digitais. Elas combinam a estrutura e a reunião de informações que as bibliotecas e os arquivos sempre fizeram com a representação digital que computadores tornaram possível" (LESK, 1997 apud ALENCAR, p. 4, 2004).

A partir das definições elaboradas por alguns autores percebe-se que ainda não existe um consenso do que realmente seja uma biblioteca digital, mas, numa interpretação pessoal, algumas semelhanças encontram-se intrínsecas nesses conceitos, como o suporte - digital - citado pela a maioria dos autores, onde é oferecido serviços e disponibilização de informação em formato digital. Outros autores falam também em agrupamentos de coleções, serviços e até pessoas em interação. Trazem ainda um conceito como a combinação de serviços de bibliotecas convencionais com as bibliotecas digitais, ou seja, para alguns autores, são bibliotecas tradicionais acrescidas do suporte digital, onde esta veio complementar e ampliar os serviços oferecidos pelas tradicionais bibliotecas permitindo uma rápida 
busca e resposta e o acesso físico dos documentos através de download dos recursos eletrônicos, apenas para citar alguns serviços oferecidos dentre tantos outros. Enfim, todos os serviços tradicionais, mas utilizando o suporte digital.

Ainda citando Alencar, ele fala das diferenças encontradas entre os conceitos elaborados:

\begin{abstract}
Estudando os conceitos é possível perceber que não existem idéias divergentes ou mesmo contraditórias entre eles. Entender as divergências não é uma tarefa difícil, sobretudo quando se pensa a questão do avanço da tecnologia, e da informática. Como falar sobre serviços ou de interatividade como chat, fóruns ou listas de discussão se essas tecnologias não haviam sido desenvolvidas ainda? Como falar em disponibilizar vídeos e áudios se não existia uma devida forma de compactação que tornasse exeqüível colocá-los na rede?Uma outra forma de entender as diferenças está na formação acadêmica de cada estudioso que, em geral, são bibliotecários, cientistas da computação, e mais raramente educadores. Esses "pontos de vista" sofrem uma forte e justa influência da formação e de seu contexto. (ALENCAR, p. 5, 2004).
\end{abstract}

A conclusão que se chega é que existem vários conceitos, como dito anteriormente, visões diferentes, mas com semelhanças encontradas entre essas definições de acordo com cada pesquisador.

Deixando de lado a conceituação do que venha a ser a biblioteca digital, submerge a descrição da evolução dessas bibliotecas, abordando a web e a importância dessa tecnologia para o surgimento e popularização de uma nova forma de prestação de informação.

A história da biblioteca digital começa a partir da criação da Internet, em 1983, quando as bibliotecas tradicionais passaram a adotar serviços que até então sem o grande advento das chamadas redes das redes não eram possíveis de ser realizados. 
Com a popularização da internet por meio, principalmente da world wide web (www) ficou mais fácil oferecer serviços como a disponibilidade de coleções, conteúdo, arquivos dentre tantos outros documentos possíveis de serem armazenados nesse meio digital.

Até o início da década de 1990 era impossível prever o tamanho do impacto que essa interconexão mundial causaria na disseminação das informações e especialmente nas bibliotecas. As bibliotecas começavam então a enfrentar profundas mudanças nos seus serviços.

A partir de 1995 houve um enorme crescimento da Internet no Brasil, passando rapidamente a ser adotada como um novo meio de comunicação. De acordo com Cunha e McCarthy (2006, p. 26) em 2000 o número de brasileiros com acesso à internet era de 10 milhões de usuários; dois anos depois, em 2002, esse número já era de 14 milhões de internautas ativos, com um tempo de navegação que ultrapassava 10 horas por mês.

Continuando os autores comentam:

Entretanto, apesar de o crescimento da internet no Brasil ser acentuado, esse dado estatístico pode ser enganador, pois, para a maioria da população, o acesso ao computador ainda é um sonho. Os dados do IBGE (IBGE, PNAD) referentes a 2002 atestam que, dos 170 milhões de habitantes do país, apenas 3,3\% (o equivalente a 7 milhões de habitantes) dispunham de computadores em casa. Este é um percentual pequeno, se comparado com a existência no domicílio de telefone (fixo e celular) e aparelho de televisão, respectivamente de 62 e 90, em cada 100 residências no país. Além disso, o acesso à internet e computadores, isto é, a chamada inclusão digital, é irregular no que concerne às classes sociais. Em 7 de outubro de 2003, segundo a Agência Nacional de Telecomunicações (Anatel), do total de internautas brasileiros, 42\% pertenciam à classe $A$, que tem $5 \%$ da população; $A$ classe $B$, que representa $19 \%$ dos brasileiros, representava $48,7 \%$ dos internautas. Finalmente, as classes C, D e E, nas quais se encontram $76 \%$ da população, contavam com apenas $9,3 \%$ dos internautas. O diagnóstico da 
Anatel para a pequena quantidade de internautas no Brasil em relação à população é que o problema em aumentar o acesso não está na telefonia, mas nos preços dos microcomputadores. (CUNHA; MCCARTHY, 2006, p.26)

Em suma, o desenvolvimento da biblioteca digital, seja no Brasil ou qualquer outra parte do mundo, está intimamente relacionado com a evolução da tecnologia e com o nível de renda da população.

Segundo Ferreira (2007) no Brasil as bibliotecas digitais têm se convertido em um dos tópicos mais atuais entre os profissionais da informação. É um fato reconhecido que as bibliotecas digitais revolucionarão a maneira como estudantes, professores, pesquisadores e cidadãos comuns acessarão e usarão a informação.

As bibliotecas brasileiras sempre possuíram serviços tradicionais; somente na última década as bibliotecas digitais tiveram um crescimento considerável, passando a atrair maior atenção. (CHOWDHUR; CHOWDHURY apud CUNHA; MCCARTHY, 2006, p. 26).

Como relatado anteriormente a internet teve um avanço rápido no Brasil; as tradicionais bibliotecas brasileiras começaram então a automatizar seus serviços o que implica um aumento do número de bibliotecas digitais.

Cunha e McCarthy (2006, p. 28) contextualizam as maiores iniciativas brasileiras em quatro categorias: ciência e tecnologia, educação, literatura e humanidades, história e política.

Neste contexto os autores não fazem menção a categoria "Direito" onde se encaixa as bibliotecas digitais jurídicas, embora nos exemplos que se seguem eles citam a "Biblioteca Digital Jurídica" (BDJur) do Superior Tribunal de Justiça dentro das categorias: História, Direito e Política. 
Em conclusão Cunha e McCarthy (2006, p. 51) relatam que existe uma série de fatores que favorecem o desenvolvimento da biblioteca digital no Brasil. Comentam que apesar de recente, a biblioteca digital começa a receber apoio financeiro do governo. Citam também alguns exemplos de bibliotecas digitais que tiveram sucesso: Prossiga, Biblioteca Virtual do Estudante de Língua Portuguesa e Scielo. Em algumas dessas bibliotecas, o sucesso foi tamanho que chegou a se transformar em portal, como é o caso do Scielo.

De qualquer modo, apesar da presente situação financeira, à semelhança de outros países, é visível que a internet e as bibliotecas digitais poderão executar importante papel na garantia da ampliação do acesso à informação no Brasil. A informatização do país e a criação de telecentros somente terão sentido se for possível oferecer materiais informativos de boa qualidade à população. As bibliotecas digitais constituem o único canal que tem o potencial de disponibilizar conteúdo cultural de bom nível para a nação em geral. Isso representaria a grande contribuição das bibliotecas digitais para o progresso brasileiro. (CUNHA; MCCARTHY 2006, p. 51).

Ohira e Prado (2002, p. 61) apresentam a evolução das bibliotecas em três momentos bem característicos, sendo que cada etapa da evolução é acentuada por características próprias e determinada pelas tecnologias vigentes na época. A divisão está assim condicionada:

No primeiro momento, tem-se uma biblioteca tradicional com seu espaço físico bem delimitado, com seus serviços e produtos de forma mecânica. Antes do advento da imprensa com Gutenberg, o seu acervo era formado por outros tipos de materiais (tabletes, argila, papiro e pergaminho), passando para o suporte de registro da informação em papel. A revolução na biblioteca aconteceu com a introdução dos catálogos em fichas e o abandono do catálogo sob a forma do livro. Esta etapa compreende de Aristóteles até o início da automação em bibliotecas.

No segundo momento, a biblioteca utiliza a tecnologia dos computadores nos seus serviços meios e fins, considerados os primeiros passos rumo à biblioteca eletrônica. Compreende a biblioteca moderna ou automatizada, 
em que os computadores foram usados para serviços básicos como catalogação, indexação e organização do acervo. Com o acesso on-line aos bancos de dados por meio de redes de telecomunicações, permitiu a dinamização dos processos de recuperação e disseminação da informação.

Em um terceiro momento, a biblioteca contemporânea utiliza a informação no suporte digital com o advento do suporte em CD-ROM. A biblioteca eletrônica, a biblioteca do futuro, pensada como uma nova estratégia para o resgate de informações onde o texto completo de documentos está disponível on-line. Com o surgimento da Internet, a biblioteca ganha nova dimensão: deixa de ter somente um espaço físico e ganha um novo espaço - 0 ciberespaço. (OHIRA \& PRADO 2002, p. 61)

Cunha (2000) desenha uma linha do tempo onde traça a evolução tecnológica da biblioteca, é dele a figura 1:

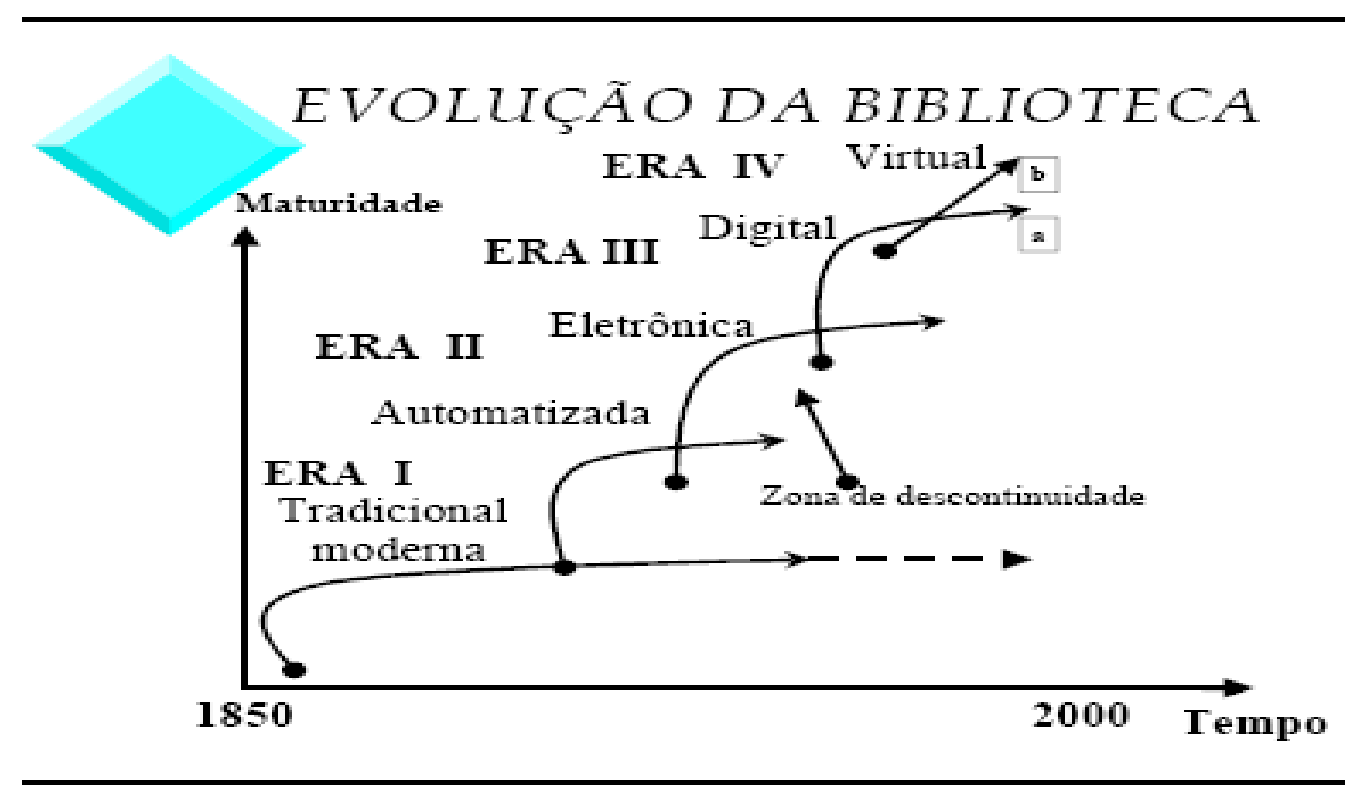

Figura 1. Evolução da biblioteca digital

Depreende-se do gráfico que a partir de 2000 muitas bibliotecas estarão automatizadas assim como muitas serão bibliotecas digitais.

Drabenstott e Burman (1997) fazem uma definição interessante de biblioteca com uma visão no futuro: 
A biblioteca digital, biônica, transmitida eletronicamente em rede - a biblioteca do século XXI - vem a ser uma potente, transparente e universal provedora de informação, também chamada de bibliotecas sem paredes. Não deixa de ser uma máquina: a máquina virtual, que, utilizando a informática e as telecomunicações, possibilita acesso a um reservatório diversificado e infinito de dados e conhecimento. Cerca vários tipos de recursos informacionais, como bibliotecas formais/convencionais, bases de dados, textos ou fontes eletrônicas, arquivos e os mais dinâmicos artefatos digitais que, de modo formal ou informal, ultrapassam os materiais tradicionais impressos, vindos das mais diversas partes do mundo. Um grande numero de usuários, tanto em nível pessoal, comercial ou acadêmico, pode acessá-la em terminais simultaneamente por conexão a redes eletrônicas internacionais, utilizando endereços eletrônicos e senhas. Novos recursos pelo rádio-vídeo e outros mecanismos tecnológicos e telemáticos a serem criados prometem superar ainda mais o acesso a informação, futuramente. (DRABENSTOTT; BURMAN, 1997)

\section{Logo depois essas autoras descrevem as fases evolutivas da biblioteca;}

1) primeiro período histórico: com as bibliotecas do tempo de Aristóteles até começos da automação; depois: as modernas bibliotecas com seus serviços plenamente automatizados; finalmente: a fase contemporânea da biblioteca eletrônica;

2) a biblioteca em papel, seguida pela biblioteca de processos automatizados, e a biblioteca digital, com artefatos armazenados eletronicamente. (DRABENSTOTT E BURMAN, 1997)

As autoras, acima citadas, dividem em dois grupos, segundo diversas opiniões, as fases evolutivas da biblioteca mas essas visões poderiam ser sintetizados em apenas uma, tamanha é a semelhança entre as fases descritas separadamente.

Diferentemente das bibliotecas universitárias tradicionais, as bibliotecas digitais não se localizam em um determinado prédio ou edifício e, provavelmente, muitos prédios de bibliotecas irão desaparecer. Muito embora a informação esteja se tornando cada vez mais digital. (CUNHA 2000, p. 8). 
O certo é que muita coisa já mudou desde o início da implantação das bibliotecas digitais no Brasil e a expectativa é que o uso tradicional do suporte em papel ceda cada vez mais lugar para os suportes digitais.

\subsection{Biblioteca Digital na área jurídica}

Ao estar presente na Internet, uma biblioteca digital pode atender de forma mais rápida, adequada e eficiente às necessidades de seus usuários. De acordo com Rezende (2000), essa característica se torna bastante relevante, principalmente se for uma biblioteca especializada na área jurídica, onde seus usuários necessitam de informação jurisprudencial em um menor tempo possível. Por essa razão e pela importância fundamental que a informação adquiriu, é imprescindível que o profissional da informação aprenda rapidamente a utilizar essa tecnologia.

No momento do planejamento de uma biblioteca deve-se definir seus objetivos e metas. No caso de uma biblioteca digital especializada em direito, ela será diferente das outras bibliotecas pela sua ênfase em fornecer informação focada e especializada para uma clientela distinta, de forma ágil e também antecipando as necessidades de informação de seus usuários.

É necessário conhecer a respeito da área de atuação, o que implica no conhecimento das disposições legislativas aplicadas à jurisprudência, preceitos jurídicos dos tribunais de justiça, entre outros.

Segundo Machado (2000), a comunidade jurídica necessita manipular um grande volume de informações que se desatualizam muito rapidamente. Daí a importância do profissional da informação atuar de acordo com o que dela espera a sociedade. 
De acordo com Amaral e Souza (2003), os principais usuários de uma biblioteca digital jurídica são os advogados, magistrados, juristas, ministros de tribunais, pesquisadores, legisladores, desembargadores, curadores, corregedores, docentes e discentes de cursos superiores e especializações jurídicas, além da comunidade em geral. Para atender melhor os seus usuários, a biblioteca jurídica deve abrir suas portas para a Internet e utilizar as ferramentas disponíveis que vão ao encontro das características desta biblioteca, em particular: informação rápida e atualizada.

Mais uma vez a ênfase na importância dos bibliotecários saberem, no mínimo, os fundamentos básicos da Internet para que possam utilizar seus recursos de forma a melhorar os serviços prestados pelas suas bibliotecas.

\begin{abstract}
Inserir-se na Internet significa abrir novas oportunidades, pois o tempo e o espaço adquirem conceitos diferentes. A biblioteca dispondo desse recurso deixa de ser apenas depósito de informação e passa a ser um ponto de pesquisa que pode ser acessada a qualquer hora de qualquer lugar.

Disponibilizar serviços e produtos em um site na Internet, destaca a unidade de informação em posição capaz de suprir necessidades de usuários remotos, com possibilidade de mídias diferentes e serviços e produtos diferenciados como os catálogos on-line, por exemplo. (AMARAL; SOUZA, 2003).
\end{abstract}

Com o grande volume de informações com que trabalham os profissionais da área jurídica e a rapidez com que estas se desatualizam torna-se, portanto necessário, conscientizar o "bibliotecário jurídico" a disponibilizar adequadamente as informações jurídicas, para que possam vir a atuar no sentido de promover e sanar a necessidade de informação de sua clientela. Para isso o profissional da informação da área jurídica poderá recorrer às valiosas ferramentas propiciadas pelas novas tecnologias informacionais e assim poder disponibilizar a informação certa, para a pessoa certa, no momento em que esta se faz necessária. 


\subsection{DSpace}

O DSpace é um repositório digital desenvolvido pelas bibliotecas do MIT (Massachusetts Institute of Technology) que tem como objetivos recolher, preservar, gerir e disseminar o produto intelectual dos seus investigadores. Ele é o resultado de um esforço conjunto de investigação e desenvolvimento do MIT e da HewlettPackard (HP).

O DSpace é organizado em comunidades, uma estrutura organizacional de alto nível que divide coleções em grupos relacionados. Cada comunidade contém uma ou várias coleções, que são containeres de itens relacionados. Um item é um objeto depositado de qualquer tipo: um artigo publicado, uma imagem, arquivo auditivo, ou vídeo, notas, uma apresentação, etc.

(DAVIS, 2007, tradução nossa)

O DSpace, de acordo com a Universidade do Minho, é disponibilizado livremente às instituições de investigação, sob a forma de um produto com código aberto (open source), que pode ser livremente adaptado e expandido funcionalmente, nos termos da Berkeley Software Distribution (BSD) Open Source License.

Esta plataforma de software open source possibilita às instituições:

a) Captar e descrever documentos digitais de acordo com um fluxo (workflow) adaptável aos processos específicos de uma comunidade;

b) Distribuir os documentos digitais da instituição na Web, possibilitando a pesquisa e obtenção de cópias aos utilizadores;

c) Preservar os documentos digitais a longo prazo.

O DSpace aceita todas as formas de materiais digitais, incluindo arquivos de texto, imagem, vídeo e áudio, o que possibilita custodiar os mais variados tipos de conteúdos, tais como, livros, artigos, relatórios técnicos, working papers, artigos de 
conferências, e-teses, conjuntos de dados (estatísticos, geoespaciais, etc.), programas de computador, modelos e simulações visuais, etc.

Como forma de se adaptar às necessidades específicas de cada instituição e dos seus departamentos, as possibilidades de "customização" do DSpace incluem, não só, a definição de workflows "à medida", mas também, a especificação de regras de utilização e formatos digitais suportados.

O DSpace permite a aplicação de variadas técnicas de recuperação de perdas (disaster recovery) com o objetivo de garantir a segurança dos documentos digitais submetidos a depósito. Algumas destas técnicas consistem na realização de cópias de segurança e espelhamento do suporte físico (i.e., a migração de um suporte físico obsoleto para outro mais atual). Além disso, a cada item é atribuído um identificador persistente de forma a assegurar a sua recuperação na ocorrência de uma deslocação dos dados.

O DSpace implementa um mecanismo de aconselhamento aos fornecedores de conteúdos para que a documentação depositada seja fornecida nos formatos mais adequados à sua preservação a longo-prazo.

Os administradores de cada comunidade têm a possibilidade de limitar o acesso aos conteúdos, quer ao nível do item submetido, quer ao nível da coleção.

Para a pesquisa e recuperação dos itens, o processo de submissão de documentos ao DSpace permite a sua descrição usando uma versão qualificada do vocabulário de metadados do Dublin Core.

O DSpace está escrito em linguagem Java e é suportado por um conjunto de ferramentas open source, tais como, o PostgreSQL, o Tomcat e o Lucene (motor de pesquisa). 
O DSpace foi utilizado pela primeira vez em língua portuguesa pela Universidade do Minho/Portugal, que enviou cópia do programa e documentação para desenvolvimento do sistema no Superior Tribunal de Justiça.

O STJ optou por usar o programa utilizado na instalação do sistema fornecido pela Universidade de São Paulo, Departamento de Educação e Comunicação (USP/ECA), por já estarem em fase de estudos da versão mais recente do Dspace.

Para instalação do referido sistema são necessários os seguintes prérequisitos:

- Sistema Operacional Unix ou Windows;

- Ambiente Java 1.3+ (JDK);

- Banco de Dados PostgreSQL 7.3+ ou Oracle 9+;

- Conteiner Java Tomcat 4.1.18+;

- Ant 1.5+ (Ferramenta de configuração).

Todos esses softwares são livres e gratuitos, podendo ser copiados livremente da Internet.

A Secretaria de Tecnologia da Informação (STI) do Superior Tribunal de Justiça foi encarregada de dar o suporte, ajuda inicial e treinamento em relação às fases de instalação e personalização do programa junto aos órgãos que tiverem interesse em integrar o Consórcio.

A Seção de Informação Digital (SINDI), da Coordenadoria da Biblioteca Digital (CBID), também disponibilizou a sua equipe para realizar treinamentos e fornecer todo tipo de informação necessária ao melhor desenvolvimento no sistema junto ao órgão.

Um estudo recente feito a partir de uma avaliação de repositórios institucionais e a instalação do DSpace na faculdade de Cornell chegou a conclusão 
que o software é pouco utilizado pelas universidades onde foi feita a pesquisa. $O$ resultado a que se chegou foi:

"Muitas das suas coleções são vazias, e a maior parte de coleções contêm poucos itens. Aquelas coleções que experimentam o crescimento constante são coleções nas quais a universidade fez um investimento administrativo, e estão necessitando de depósitos de teses e dissertações em DSpace. A faculdade de Cornell tem pouco conhecimento e pouca motivação para usar DSpace." (DAVIS, 2007, tradução nossa)

O estudo mostra ainda que muitas faculdades preferem usar outras alternativas como as páginas da web pessoais e repositórios disciplinares, que são concebidos para ter uma maior participação da comunidade e não uma instituição afiliada de alguém, a usar repositórios institucionais. As razões citadas para usar páginas da web de grupo pessoal para disponibilizar documentos digitais foram tranqüilidade e o controle do seu conteúdo. De acordo com o estudo, a faculdade deu muitas razões para não usar repositórios, a saber: a redundância com outros modos de disseminar informação, a curva de aprendizagem, confusão com direitos autorais, o medo do plágio e ter trabalho de alguém copiado.

As razões para usar um repositório digital, quando uma página da web de grupo pessoal, departamental, ou de laboratório pode servir como um recurso da disseminação de documentos digitais é a permanência, ou seja, uma página da web pode modificar-se, já com o arXiv, não há a necessidade de dirigi-lo, pois existe a possibilidade de migração de dados. O PDF é o padrão de documentos usado hoje, mas tem a possibilidade de mudanças desses documentos em formatos que podem ser lidos pelo futuro software. As razões de não usar um repositório digital seria associação de qualidade, medo de plágio e de ser copiado, reputação e a importância de exatidão dentre outras.

A conclusão a que se chegou foi: 
"DSpace de Cornell é basicamente subpovoado e subutilizado pela sua faculdade. A sua organização complexa é vista em instituições comparáveis, mas pode descoroçoar contribuições para DSpace fazendo-o parecer vazia. Além do mais, a faculdade têm um pouco de conhecimento de e nenhuma motivação para usar DSpace.". (DAVIS, 2007, tradução nossa)

\subsection{Estudo de Usuário de Biblioteca Digital}

São comuns os estudos de usuário na ciência da informação. A área se preocupa tanto com as necessidades de informação das pessoas como a forma que esses carentes de informação a busca.

Atualmente com o desenvolvimento da Internet, novos sistemas e fontes de informação têm sido criados, colocando o usuário em um novo contexto de busca de informação. Em vista disso, autores da ciência da informação têm se dedicado aos estudos de usuários nesse novo ambiente. (BOHMERWALD, 2005, p. 95)

De acordo com Saracevic (2000) a avaliação de bibliotecas digitais é um empreendimento complexo e assim, é um desafio conceitual e pragmático. Isso porque cada um tem um conceito e uma definição diferentes, afetando a natureza conceitual da avaliação. Isto se traduz em perguntas específicas como: O que é uma biblioteca digital? O que há para avaliar? Quais são os critérios? Como os aplicar na avaliação? Por que avaliar bibliotecas digitais em primeiro lugar?

Continuando, o autor fala das exigências essenciais para a avaliação de bibliotecas digitais, elaborando as questões: $\mathrm{O}$ que devemos avaliar? Com que finalidade a avaliamos? Quem deve avaliar? Em que nível avaliamos? Sob que critérios avaliamos?

Todas essas perguntas devem servir como uma base para a seleção de uma ou várias formas apropriadas para se chegar a uma avaliação de bibliotecas digitais. Assim, a avaliação significa um valor do desempenho ou do funcionamento de um 
sistema ou de uma parte dele, com relação a um ou diversos objetivos desse sistema.

De acordo com Rosa (2004), "a usabilidade é a facilidade de uso que as pessoas podem empregar uma ferramenta ou objeto a fim de realizar uma tarefa especifica".

E essa usabilidade pode ser avaliada de acordo com alguns desempenhos que Saracevic (2000) cita:

- Eficácia: Quão bem um sistema (ou algum de suas partes) executa aquilo para que foi projetado? Ou para:

- Eficiência: Com que custo? (os custos poderiam ser financeiros, tempo ou esforço). Ou para:

- Uma combinação de custo-benefício.

Ainda segundo esse autor, numa avaliação devem ser considerados os aspectos culturais e as limitações dos usuários.

Nesse contexto Borgman (2004) fala de usabilidade de bibliotecas digitais em um ambiente multicultural explicando que a usabilidade é algo complicado para bibliotecas digitais, pelo fato dos usuários terem variados níveis de conhecimento de sistemas de biblioteca; o que implica na multiculturidade é o fato dos usuários dessas bibliotecas virem de variadas culturas e nações criando assim a necessidade da biblioteca orientar esses usuários de localidade ou cultura específica.

Este autor divide a avaliação da usabilidade de uma biblioteca digital em quatro tipos, a saber:

Inicial Formativa: começa nos estágios iniciais de um projeto de desenvolvimento para estabelecer linhas de base nas operações atuais, ajustar os objetivos, e determinar os resultados desejados para que tal avaliação é dirigida, geralmente pelo contexto e por objetivos de projetosespecíficos. 
Síntese: ocorre no fim de um projeto para determinar se os objetivos pretendidos foram alcançados, os resultados devem ser comparados aos estados iniciais, assim a avaliação formativa precede geralmente a essa avaliação.

Evolução Cíclica: ocorre durante todo o projeto, começando nos estágios mais adiantados e do ínterim dos estágios de desenvolvimento do projeto, são avaliados na comparação para projetar objetivos e resultados desejados, e os resultados informam os estágios seguintes do projeto, que as aproximações iterativas auxiliam no ajustamento dos objetivos mensurados no começo do projeto e assim fornece oportunidades de reavaliação dos objetivos durante todo o processo de desenvolvimento.

Evolução Comparativa: requer as medidas estandardizadas que podem ser comparadas através dos sistemas e as comunidades podem identificar e validar essas medidas. Se tais medidas forem executadas de uma maneira consistente, permitem comparações entre camadas do teste dos sistemas, é uma outra maneira para comparar medidas e o desempenho de diferentes funções. (BORGMAN, 2004, p. 276, tradução nossa).

Theng (2004) comenta um estudo de uma avaliação quantitativa e qualitativa da Biblioteca Nacional de Singapura e os esforços para melhorar a utilidade e a usabilidade da Biblioteca Nacional da Singapura. No estudo quantitativo foi avaliado a eficácia de um software, o elibraryhub, o estudo que foi conduzido em 2003, considerou os usuários, os usos, a utilidade e a facilidade de utilização da biblioteca digital; tentou ainda empregar uma aproximação quantitativa baseada no exame de questionário para avaliar o valor percebido da biblioteca digital e o efeito na intenção do uso por usuários.

Já no estudo qualitativo foi examinado a disposição da estrutura e da informação da navegação do eLibraryhub. Conseqüentemente, os objetivos deste estudo, conduzido em um período de duas semanas, de 24 de fevereiro de 2003 a 6 de março de 2003, são: 
- Investigar a usabilidade do eLibraryhub usando a técnica estabelecida da usabilidade de identificar conseqüências positivas e negativas das características do projeto; e

- Propor o refinamento para aliviar as conseqüências negativas das características do projeto, melhorando desse modo a usabilidade do eLibraryhub, especialmente com relação à disposição navegacional e a estrutura da informação. (tradução nossa)

Tendo em vista o aumento da usabilidade em biblioteca digital, como dito anteriormente, fez-se necessário realizar pesquisas que estudassem a satisfação dos usuários em relação aos serviços prestados por esses centros de informação. Isso porque se a homepage da biblioteca for difícil de usar, não mostrar suficientemente os serviços que oferece, se há demora no carregamento da página ou ainda, se o usuário se perde em suas pesquisas ele acaba desistindo e saindo; para evitar esse tipo de problema deve-se pensar no designer das interfaces visando a efetividade, eficiência e satisfação final na prestação dos serviços.

Voltando um pouco ao passado, antes do advento das bibliotecas digitais, os usuários das tradicionais bibliotecas sabiam o necessário para encontrar os documentos que procuravam. Entretanto, com o surgimento da tecnologia surgiu uma nova exigência, a necessidade de novas habilidades como saber digitar, manipular o mouse, decifrar e usar os vários tipos de interfaces, por meio de menus, habitualmente pouco amistosos, com baixas taxas de usabilidade e com pouco ou nenhum mecanismo de prevenção de erros. (KAFURE; CUNHA, 2006).

Esses usuários dotados de diferentes habilidades computacionais, para definir as buscas, necessitam conhecer sintaxe dos programas e dos bancos de dados e, também, o vocabulário controlado de muitos deles, além de saberem utilizar os operadores lógicos. (LEVACOV 2000 apud KAFURE; CUNHA, 2006). 
Vale salientar que o simples fato da tecnologia estar disponível não significa necessariamente que esses novos modelos de bibliotecas irão ter sucesso na prestação de serviços, isso porque é necessário um estudo para verificar quais as necessidades e restrições dos respectivos usuários de uma biblioteca digital.

Kafure e Cunha (2006) citam três tipos de conhecimento para a concepção de Interface de Bibliotecas Digitais (IBDs), primeiro, o conhecimento dos usuários; segundo, o conhecimento da tarefa e da atividade; e terceiro, o conhecimento do design. Em vista dessa questão os autores fazem algumas recomendações para o desenvolvimento de interfaces de bibliotecas digitais, a saber:

\section{Necessidade de acesso à informação}

Os usuários interagem com a IBD porque precisam ter acesso à informação, por isso é importante:

1. Acesso direto aos documentos.

2. Acesso ao tesauro na tarefa de recuperação da informação.

3. Facilidades para recuperar os registros selecionados.

4. Possibilidade de refinamento dos resultados obtidos.

5. Disponibilidade de resumo de documento recuperado.

2 Expectativa de localizar rapidamente a informação procurada

A IBD deve facilitar a recuperação da informação, disponibilizando:

1. Representações icônicas funcionais de objetos reais e informações da biblioteca.

2. Mapas e diagramas de rotas para localizar usuários e documentos dentro da biblioteca.

3. Códigos coloridos que facilitem a identificação e organização de documentos em áreas específicas.

4. Imagens das capas dos livros.

5. Informação visual que possa guiar diferentes tipos de usuários na IBD e na biblioteca.

3. Expectativa de aprendizado fácil da imagem da IBD

As seguintes características podem dar um suporte à compreensão da IBD:

1. Interface gráfica com ícones que estejam relacionados com a tarefa e atividade do usuário. 
2. Disponibilidade de ícone que aponte a funcionalidade: "Perguntar ao bibliotecário". Isso deve permitir

a resolução de dúvidas com um bibliotecário via Internet (sala de conferência virtual).

3. Opções para poder visualizar pesquisas anteriores.

4. Pequenos filmes que ilustrem as funcionalidades da interface.

5. Uso de linguagem familiar ao usuário.

4. Expectativa de uso fácil da imagem da IBD

Os usuários podem contar com uma interface fácil de usar, sendo disponibilizada:

1. Correspondência entre os ícones e suas funcionalidades.

2. Visualização dos resultados classificados por autor, título, data de publicação, editor, entre outros.

3. Sugestões de escritura para corrigir problemas de sintaxe.

4. Predição das ações dos usuários ilustrando as diferentes opções que este teria para realização da tarefa.

5. Possibilidade para cancelar as ações recentemente executadas. (KAFURE; CUNHA, 2006).

Conclui que a partir das recomendações que a ciência e a tecnologia não são suficientes, além delas é necessário que "haja compatibilidade entre a imagem disponibilizada na IBD e o modelo mental que os usuários possuem da tarefa" (KAFURE; CUNHA, 2006); uma outra forma de saber as características positivas e as limitações dos usuários com relação a uma biblioteca digital é aplicar um teste de satisfação com esses usuários para saber quais as expectativas destes e assim antecipar os seus desejos e mostrar onde encontra o que procura; é este afinal, o principal propósito da avaliação da Biblioteca Digital Jurídica do Superior Tribunal de Justiça que será feita sob o ponto de vista institucional, onde as respostas para as questões deverão responder se os usuários estão satisfeitos com os serviços prestados pela biblioteca. 


\section{METODOLOGIA}

A pesquisa teve caráter exploratório e foi realizada por meio de um estudo de caso, com a utilização de técnicas de investigação quantitativa por meio de um questionário disponibilizado do dia 17 de abril de 2007 a 10 de maio de 2007, no site da BDJur, na Intranet e Internet. Foi avisado aos usuários por meio de destaques na página do Superior Tribunal de Justiça e e-mails para todos os usuários cadastrados no sistema. O objeto de pesquisa foi a Biblioteca Digital Jurídica do Superior Tribunal de Justiça.

Este capítulo foi dividido nos seguintes itens: universo e amostra, a coleta de dados e seu instrumento.

\subsection{Universo}

O universo da pesquisa foi composto pelos os usuários cadastrados da BDJur até 17 de abril de 2007, num total de 9.083.

\subsection{Amostra}

Para este estudo, definiu-se como população os usuários da BDJur. De acordo com as características da população, foi utilizada uma amostragem aleatória simples dentro de cada estrato, cuja determinação do tamanho seguiu o método para amostras de população finitas.

O tamanho do universo era 9.083 usuários cadastrados na BDJur, mais a população indefinida de usuários não cadastrados. A quantidade de questionários respondidos foi de 653 usuários cadastrados, mais 130 usuários não cadastrados, totalizando 783 respondentes. 


\subsection{Instrumentos de coleta de dados}

A coleta de dados foi realizada por meio de um questionário com 15 perguntas fechadas e três abertas, disponibilizado na página da Intranet e Internet da BDJur.

O instrumento utilizado para coleta de dados foi o questionário (Anexo B) com 18 questões, disponibilizado na página da BDJur na Internet e Intranet no período de 17/04/2007 a 10/05/2007. Foi enviado um e-mail (Anexo A) para todos os usuários da BDJur.

O questionário foi pré-testando tendo várias versões. Numa primeira versão com 14 questões fechadas, foram feitas pequenas modificações e acrescentadas 3 perguntas abertas, por sugestão do Professor Orientador.

Numa segunda versão, em detrimento a limitações do Sistema de Pesquisa do STJ, o questionário teve várias alterações, indo para a Internet e Intranet com uma versão muito grande para uma boa coleta de dados. Para corrigir esse problema, o questionário foi suspenso por uma semana, voltando com terceira e atual versão.

Nesta versão final, a pesquisa foi dividida em dois blocos.

O primeiro bloco foi subdivido em cinco partes, que serão explicados a seguir:

Primeira parte: Procurou-se traçar o perfil dos usuários da Biblioteca Digital do Superior Tribunal de Justiça, observando o grau de formação mais elevado e o cargo que ocupa no Superior Tribunal de Justiça; a terceira questão era aberta e indagava a profissão daqueles que não fossem Servidor/Colaborador do STJ;

Segunda parte: A quarta questão era referente ao uso da BDJur, caso a utilizasse, especificar há quanto tempo. A quinta pergunta questionava se o usuário estava inscrito no serviço de "Alertas por e-mail" da BDJur, em caso positivo, 
descrever por extenso em uma questão aberta, quais coleções estavam cadastradas; nesse bloco tinha uma terceira indagação que questionava se o usuário da BDJur era cadastrado, em se tratando de resposta afirmativa, deveria especificar há quanto tempo;

Terceira parte: Pretendeu-se verificar o grau de satisfação dos usuários em relação aos serviços da BDJur e conhecer suas opiniões dos usuários em relação à Biblioteca. A primeira pergunta era se o usuário já fez contato com a equipe do BDJur, o respondente tinha as opções de demonstrar se já tinha feito contato e se foi atendido pela a equipe da BDJur;

Quarta parte: Aspirou-se verificar o grau de satisfação dos usuários em relação à BDJur; seguiu uma seqüência de seis indagações no que diz respeito ao layout, interface de pesquisa, organização das coleções, qualidade do conteúdo, organização da ferramenta e clareza dos objetivos das coleções; numa sétima pergunta buscou-se constatar finalmente, de uma maneira geral, que nota atribuiria à BDJur;

Quinta parte: Numa única pergunta, aspirou-se reunir informações que possam promover melhorias nas condições da BDJur através da indagação aberta, onde o usuário sugeriria para melhorar os serviços oferecidos pela BDJur.

Segundo bloco: Neste segundo bloco foi questionada a freqüência de uso de cada coleção. 


\section{ANÁLISE E DISCUSSÃO DOS DADOS}

Para a tabulação dos dados foi utilizado o Sistema de Pesquisa do Superior Tribunal de Justiça já utilizado para valorizar diversos serviços do Tribunal.

O sistema é dividido em 3 partes:

$1^{0}$ - Nessa aplicação do sistema de pesquisa o interessado formula a pesquisa de acordo com sua necessidade informando ao sistema quais são as perguntas e as referentes opções de resposta que o usuário terá. Após a formulação das questões, a pesquisa deve ser "Aprovada" via sistema, e em seguida a pesquisa deve ser disponibilizada no local desejado Internet/Intranet, para que enfim possa ser respondida pelo usuário.

$2^{\circ}$ - O sistema de pesquisa grava os dados das respostas em banco de dados de acordo com a identificação de quem responde à pesquisa, vinculando assim cada opção de resposta à identificação informada, isso impede que um usuário responda mais de uma vez a mesma pesquisa.

$3^{\circ}$ - A cada momento em que a pesquisa é respondida a pessoa que a criou tem toda liberdade de recuperar esses dados de pesquisa podendo formatá-los da forma que achar necessário.

Os dados coletados foram analisados em duas fases: a primeira refere-se à análise estatística das questões fechadas do questionário e a segunda à análise das questões abertas.

\subsection{Análise dos itens do questionário aplicado}

A pesquisa de opinião ficou na Internet e Intranet da BDJur no período de 17/04/2007 a 10/05/2007 colhendo um total de 783 questionários respondidos; as respostas colhidas mostram os seguintes resultados: 


\section{- Perfil do usuário}

\section{Questão 1: Grau de formação mais elevado:}

Nessa questão o que surpreendeu foi à presença de usuários com nível fundamental; de acordo com o gráfico 1, foram cinco ao total. Provavelmente tratase de estagiários de nível médio do STJ. A pergunta permitia ao usuário responder, como grau de formação mais elevado, o doutorado, no entanto quando questionado a profissão, numa futura questão aberta, tiveram alguns usuários que se identificaram com pós-doutorado. O que comprova que o nível de escolaridade de quem usa a BDJur é bastante elevado.

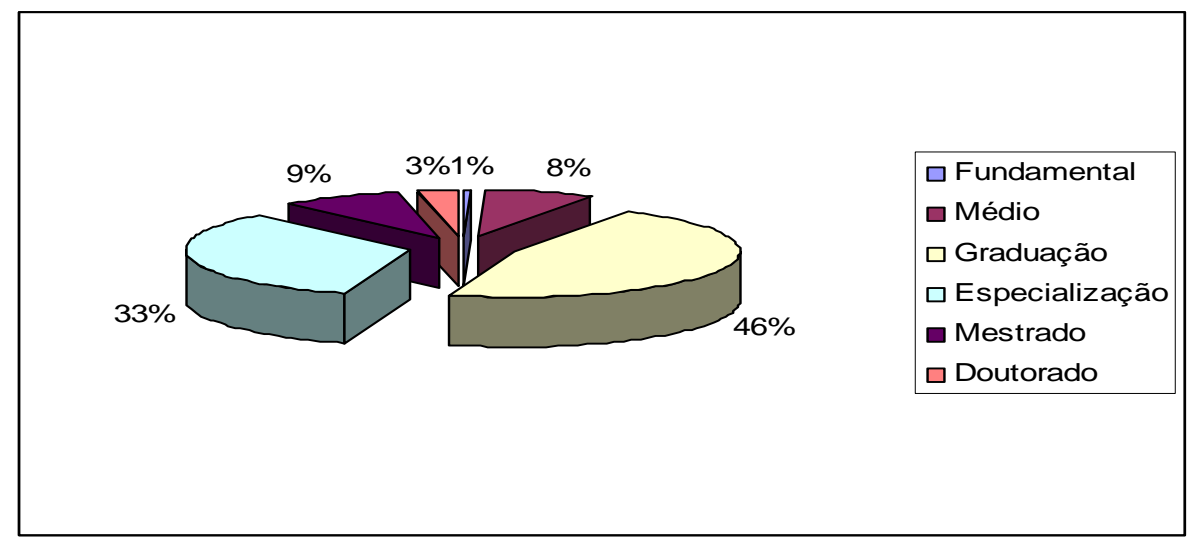

Gráfico 1: Grau de formação mais elevado

\section{Questão 2: Qual o Seu cargo?}

Essa pergunta questionava o cargo do usuário, se servidor/colaborador do STJ ou, se usuário externo, deveria especificar a profissão, numa questão aberta.

O resultado mostra que 55\% dos respondentes são usuários externos, ou seja, não têm qualquer vínculo trabalhista com o STJ, o que não é uma surpresa tendo em vista que a BDJur é de acesso público; os usuários internos respondem a $45 \%$ do total, como mostra a gráfico 2 : 


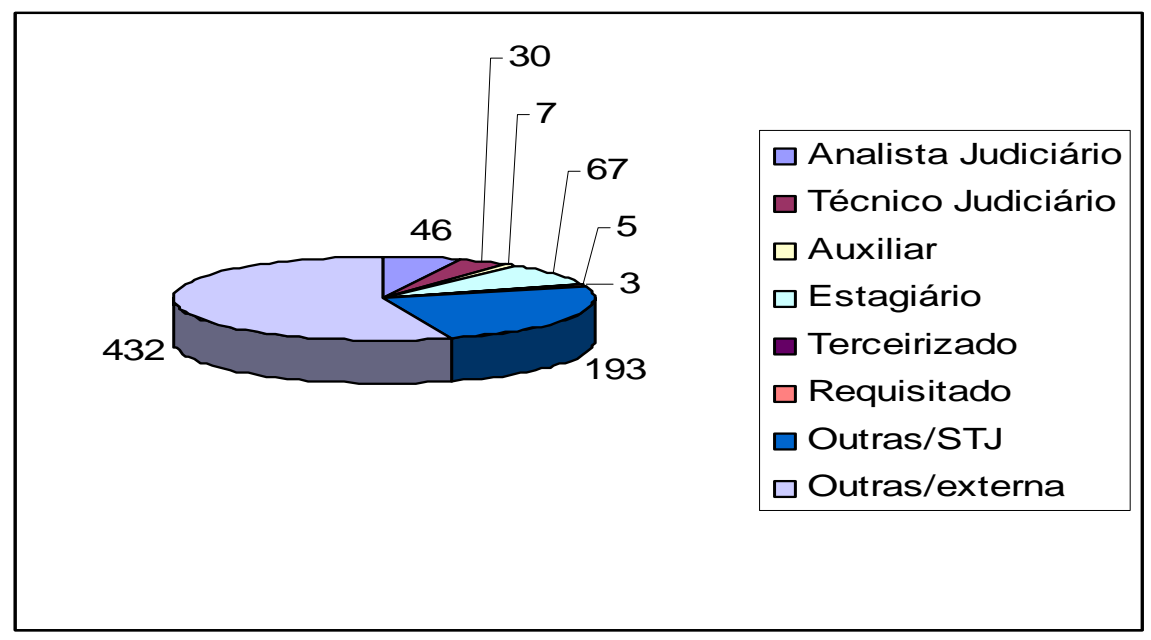

Gráfico 2: Cargo

\section{Questão 3: Qual sua profissão? (Caso não seja Servidor/Colaborador do} STJ)?

A questão que perguntava a profissão daqueles que não eram servidores/colaboradores do STJ, era aberta e, portanto não deu para quantificar, em função da grande variedade de respostas, mas têm algumas que se destacam, por exemplo: advogado é a grande maioria; seguido por professores universitários da área jurídica e estudantes de direito; tiveram ainda juízes, procuradores, auditores, ministro aposentado, entre outros magistrados da área de direito em geral, além de delegados, policiais militares, bibliotecários, engenheiros e até uma dona de casa e um taxista. A surpresa quanto a essa penúltima usuária justifica-se pelo o público esperado da BDJur, por se tratar de uma biblioteca digital jurídica, com conteúdo totalmente voltados para esse campo do conhecimento, supunha-se que seus usuários fossem tão somente pessoas com interesse nessa área de informação, porém, como já dito anteriormente, por se tratar de uma biblioteca com 
acesso público, induz-se que nesse caso ela encontrou a BDJur em alguma pesquisa e acabou por fazer o cadastro em função de provável interesse.

\section{Questão 4: Você utiliza a BDJur? Há quanto tempo?}

Na pergunta pretendeu-se saber se o respondente utiliza a BDJur e em caso positivo, há quanto tempo; a surpresa foi a presença de 57 respondentes que se identificaram como não usuários da BDJur, no entanto, infere-se que essas pessoas utilizaram a Biblioteca em época anterior, caso contrário, dificilmente teriam acesso à pesquisa. Considerando como usuários experientes aqueles com um ano ou mais de uso da BDJur, esse percentual foi de apenas $23,76 \%$ dos usuários, fato explicado pelo o pouco tempo de existência da BDJur; em contrapartida foram 76,24\% usuários com menos de um ano de utilização, conforme pode ser observado na gráfico 3:

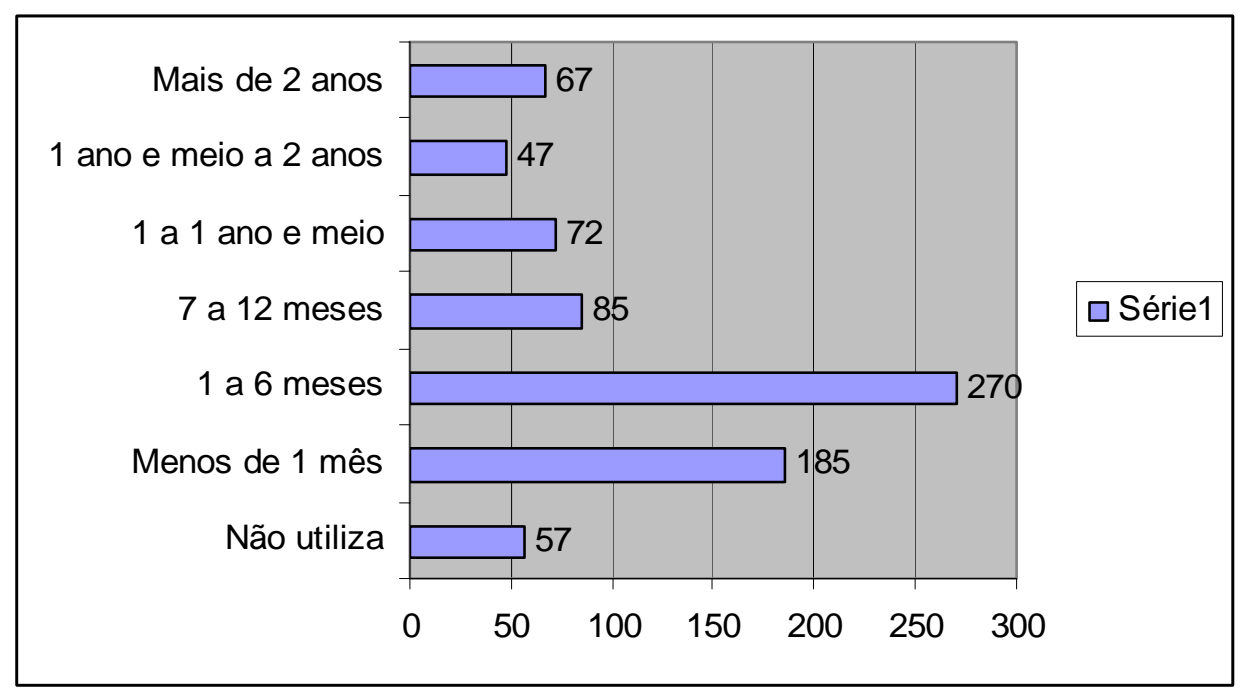

Gráfico 3: Tempo que utiliza a BDJur

Questão 5: Você esta inscrito no serviço "Alertas por e-mail" (para ser notificado de novos depósitos da BDJur)? 
A pergunta questionava se o usuário estava inscrito no serviço "Alertas por email" (para ser notificado de novos depósitos da BDJur) e o resultado mostra que o serviço é pouco usado; foram apenas 136 usuários respondentes que estavam cadastrados nesse serviço contra um alto percentual de 647 usuários que não estavam cadastrados; especula-se se a causa da baixa utilização do serviço seria a falta de divulgação, ou ainda, uma segunda opção provável do alto grau de nãoutilização desse serviço, seria a falta de interesse do usuário, tendo em vista que este terá sua caixa de e-mail diariamente ocupada com novas mensagens informando-o sobre o depósito de novos itens inseridos nas coleções em que o usuário estiver inscrito.

\section{Questão 6: Em caso de afirmativo, em quais coleções?}

As opções de respostas permitem ao usuário responder negativamente e em caso de resposta positiva seguia-se para essa pergunta onde o usuário deveria citar por extenso em quais coleções estava inscrito, no entanto mesmo os que responderam sim, que estão inscritos, não descreveram em quais coleções, a sua grande maioria limitou-se a responder que não lembrava; é possível que esses usuários não lembraram o conceito usado, fato observado em respostas com as quais os nomes da coleções estavam erradas; as respostas podem ser conferidas na gráfico 4, de onde depreende-se que o serviço é muito pouco utilizado: 


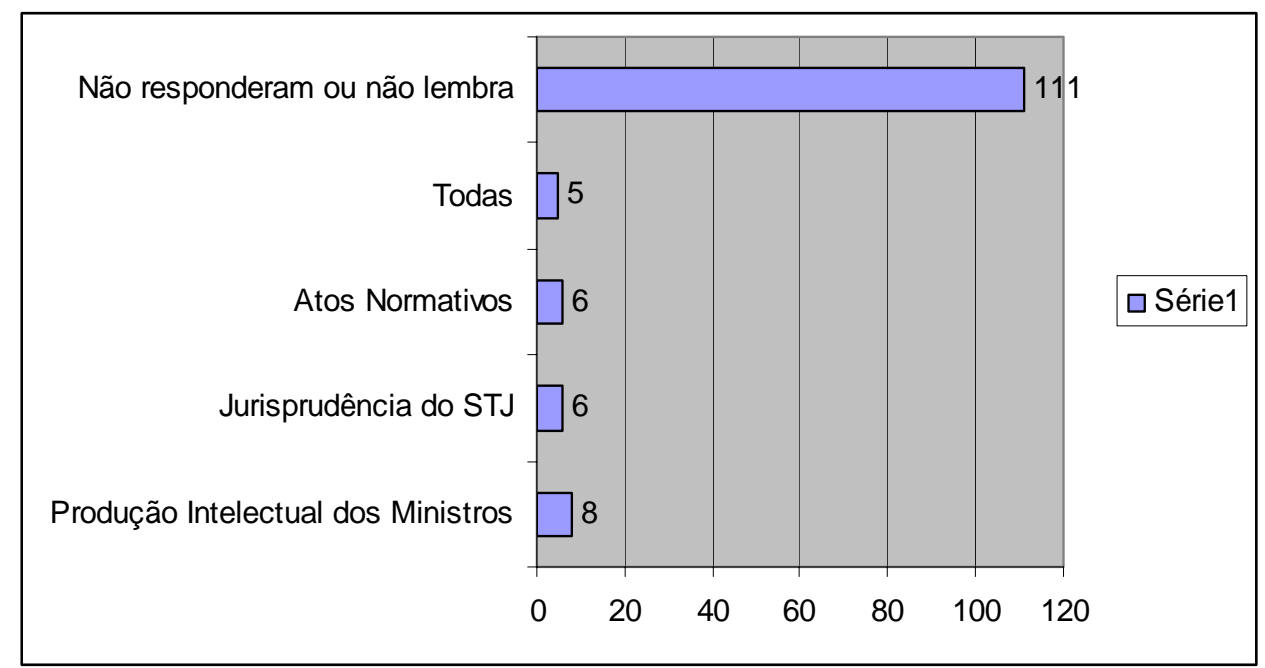

Gráfico 4: Coleções inscritas no serviço "Alerta por e-mail"

Para tentar explicar a causa dessa ausência de uso, foi feito um cruzamento entre os usuários que não estão inscritos com o grau de formação e o resultado, conforme mostra o gráfico 5 , ratifica que não existe, do ponto de vista estatístico, uma relação direta entre o grau de formação do usuário com a inscrição no serviço.

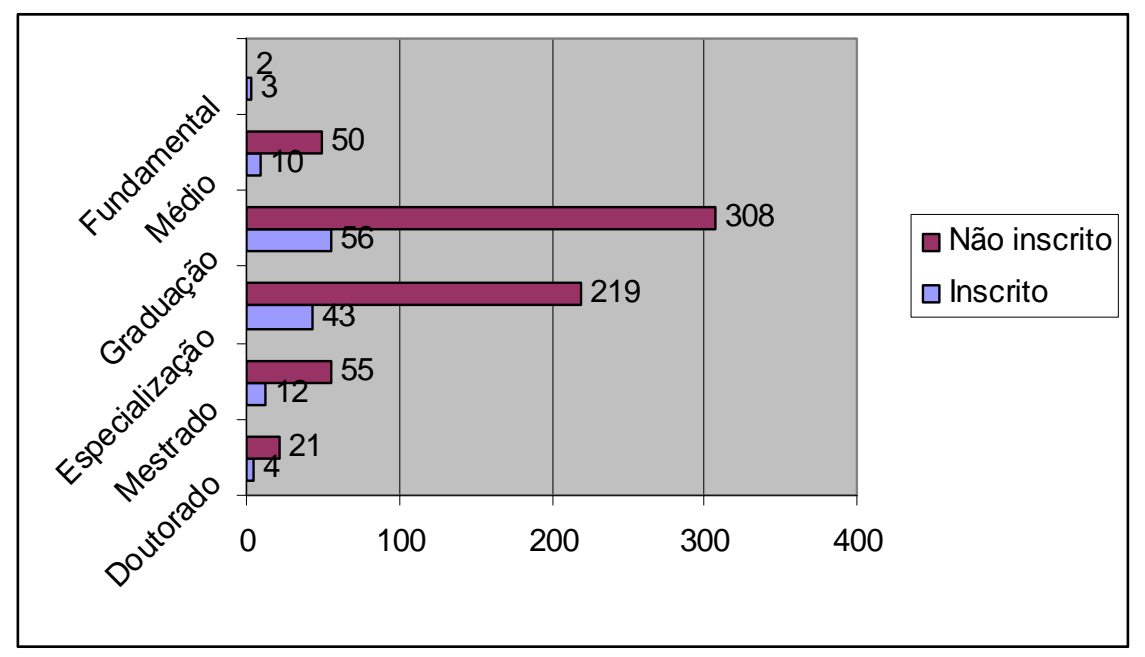

Gráfico 5: Cruzamento de inscritos no serviço de "Alerta por e-mail" com o grau de formação

\section{- Grau de satisfação do usuário}

A próxima seqüência de perguntas pretendeu-se verificar o grau de satisfação dos usuários em relação aos serviços da BDJur. 


\section{Questão 7: Já fez contato com a equipe da BDJur? Foi atendido em sua}

\section{solicitação?}

A primeira pergunta era se o usuário já fez contato com a equipe da BDJur, e em caso positivo se foi atendido em sua solicitação, segundo o gráfico 6 pôde ser observado que o índice de solicitações não atendidas ainda é alto, o que não significa que o percentual de 38\% não seja bastante representativo.

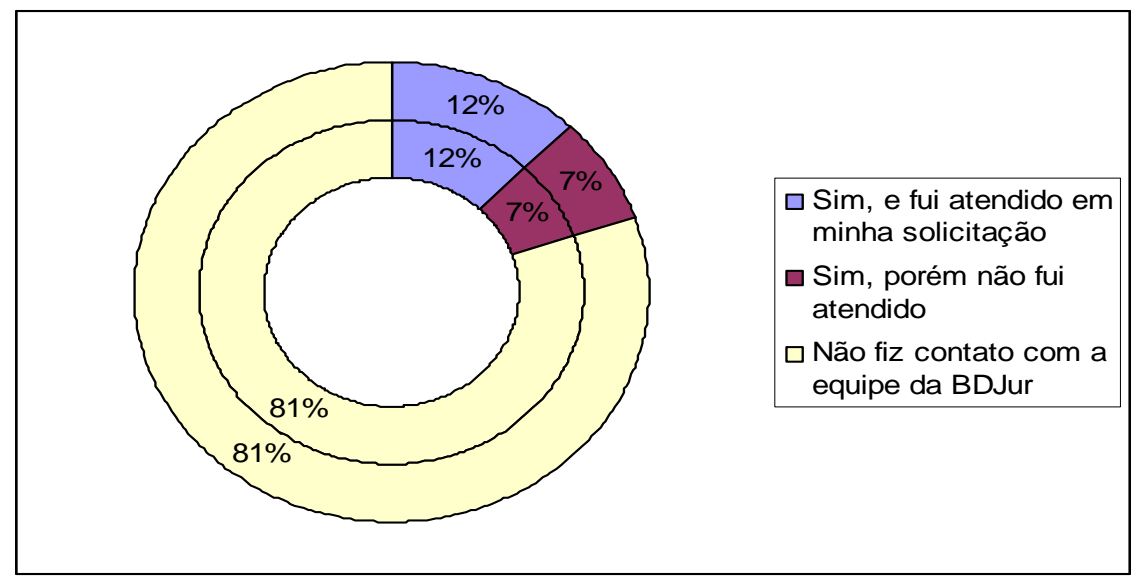

Gráfico 6: Contato com a BDJur

Para demonstrar quem são esses usuários que não foram atendidos em suas solicitações e tentar uma possível explicação para esse fato, fez-se um cruzamento entre esses solicitantes e o cargo que exerce no STJ ou se não são servidores/colaboradores do Tribunal.

Foi demonstrado que o número de solicitações não atendidas é maior entre os usuários que não trabalham no STJ, mas essa falha pode ser explicada levandose em consideração que são esses usuários externos que mais fizeram solicitações à BDJur e principalmente, se esses pedidos estão ligados aos objetivos da BDJur.

O resultado pode ser conferido no gráfico 7 : 


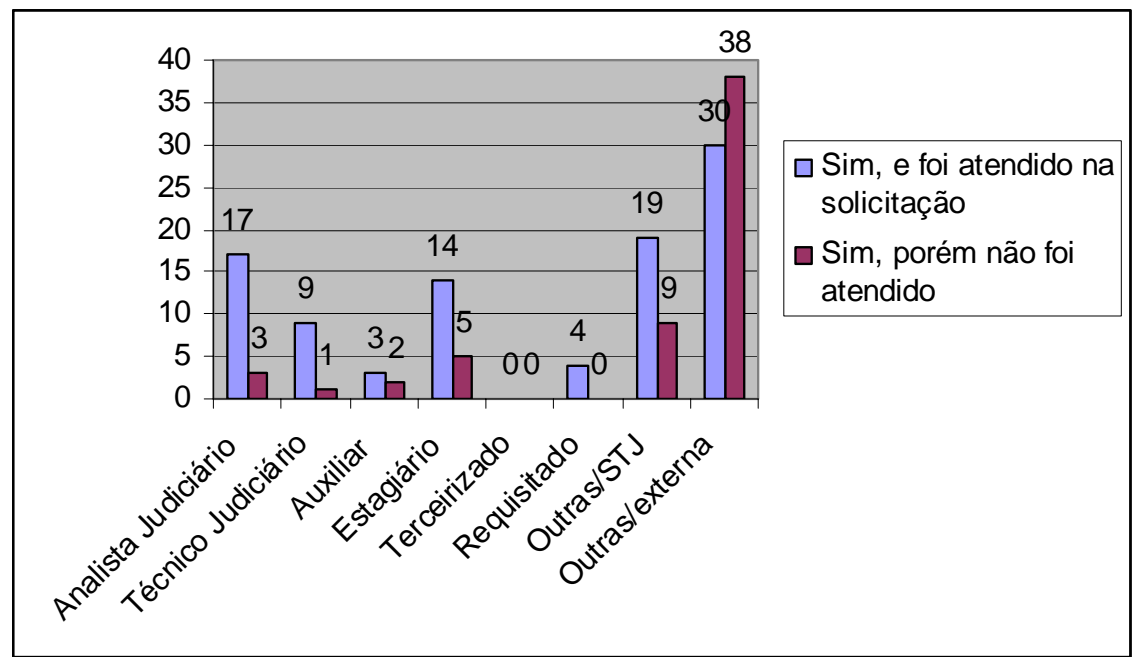

Gráfico 7: Cruzamento do número de solicitações atendidas/não atendidas com o cargo do usuário

A seguir fez-se uma seqüência de perguntas onde o usuário deveria avaliar os seguintes itens: Layout da BDJur, interface de pesquisa da BDJur, a organização das coleções da BDJur, a qualidade do conteúdo da BDJur, a organização da ferramenta da BDJur, a clareza dos objetivos das coleções da BDJur, o resultado de pesquisa da BDJur e finalmente, a BDJur de uma maneira geral.

\section{Questão 8: Como avalia o Layout da BDJur?}

O primeiro item avaliado foi o layout e considerando os parâmetros "Bom" e "Excelente" como satisfatório, percebe-se, de acordo com o gráfico 8, que 79\% dos usuários estão satisfeitos com o layout da BDJur. 


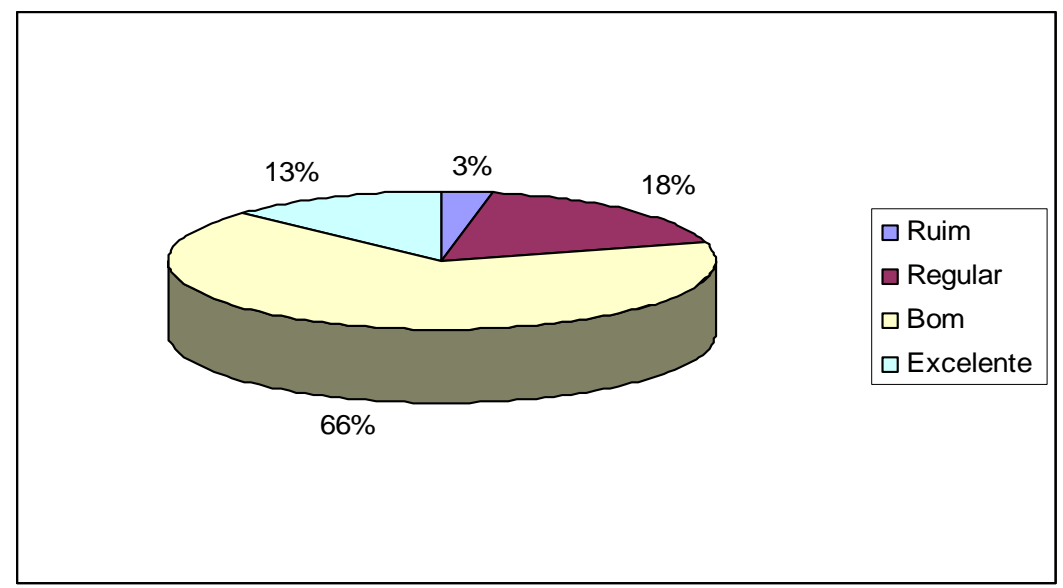

Gráfico 8: Satisfação com relação ao layout da BDJur

\section{Questão 9: Como avalia a Interface de pesquisa da BDJur?}

Kafure e Cunha (2006) citam três tipos de conhecimento para a concepção de Interface de Bibliotecas Digitais (IBDs), primeiro, o conhecimento dos usuários; segundo, o conhecimento da tarefa e da atividade; e terceiro, o conhecimento do design. Em vista dessa questão quando $73 \%$ dos usuários responderam bom ou excelente para a pergunta com relação à satisfação da interface da BDJur, isso significa que a interface da Biblioteca é amigável; que ela foi feita pensando-se na capacidade que a Interface Humano-Computador (IHC) oferece para a recuperação da informação com efetividade, eficiência e satisfação; e finalmente que, o usuário conhece a programação visual de sua interface. Ainda segundo os autores citados, a "qualidade da comunicação entre o usuário e a interface depende fortemente da compatibilidade (adequação) entre o modelo mental do usuário e a imagem da IBD", ou seja, o usuário tem a idéia na cabeça de localizar rapidamente a informação procurada, além de aprendizado e uso fácil da imagem da IBD para ter acesso à informação desejada e se isso não acontece, o usuário desiste da pesquisa e certamente não voltará a fazer futuras buscas nessa biblioteca digital. 


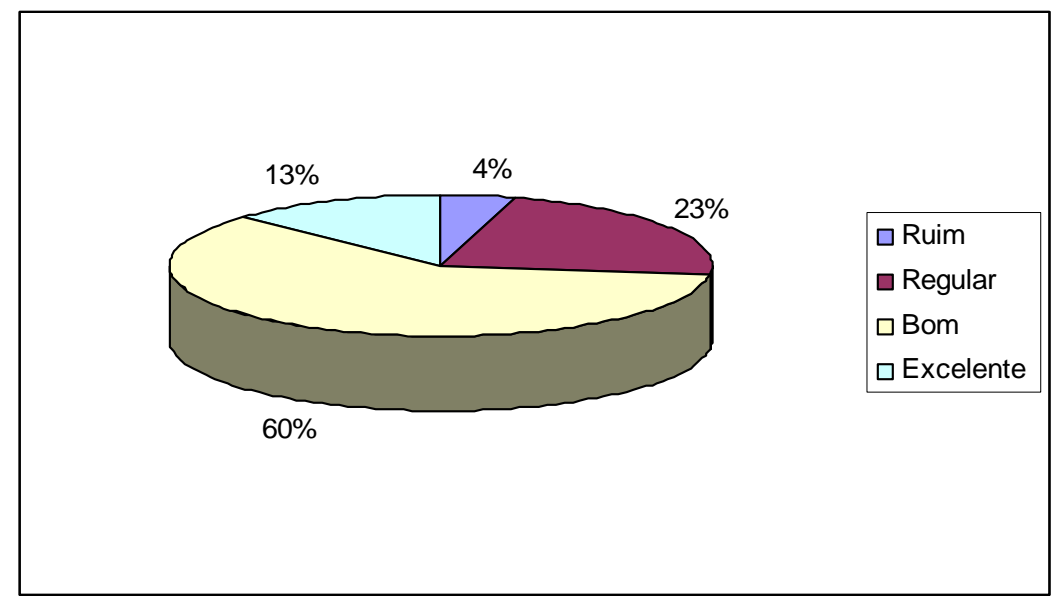

Gráfico 9: Satisfação com relação à interface de pesquisa da BDJur

\section{Questão 10: Como avalia a organização das coleções da BDJur?}

A organização das coleções da BDJur é outro item com o qual os respondentes estão satisfeitos, equipara-se a interface de pesquisa com $76 \%$ de aprovação por parte dos usuários, como pode ser observado no gráfico 10. Vale lembrar que quando questionado a respeito de sugestões para melhoria da BDJur, esses usuários que se posicionaram e responderam "Ruim" ou "Regular" para essa questão citaram a divisão das coleções como sendo confusa.

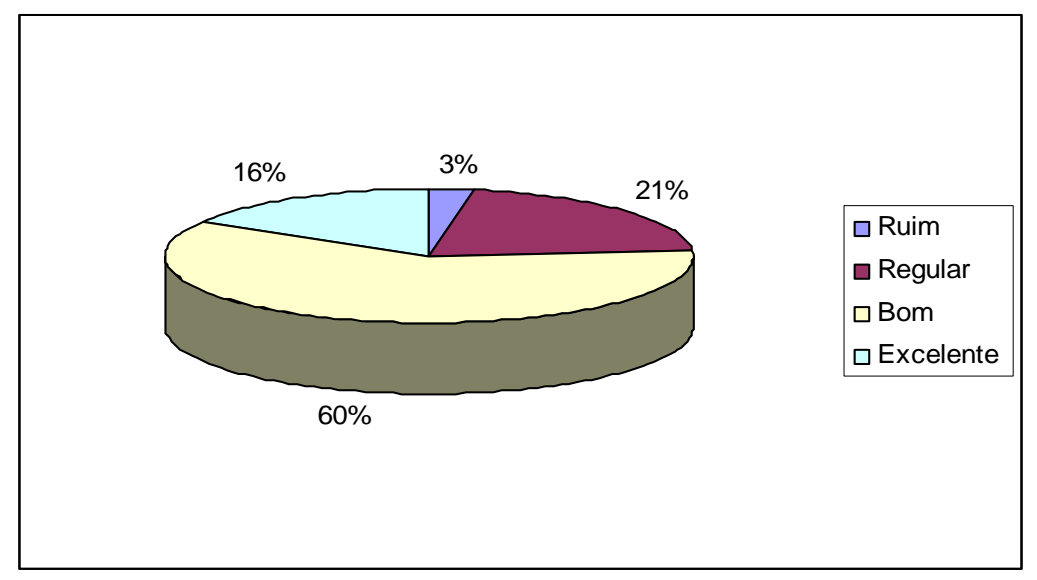

Gráfico 10: Satisfação com relação à organização das coleções da BDJur 


\section{Questão 11: Como avalia a qualidade do conteúdo da BDJur?}

Quando $86 \%$ dos usuários responderam bom ou excelente para a qualidade do conteúdo, pode-se afirmar que o teor dos documentos da BDJur é de alta qualidade e satisfaz a necessidade de informação de seus usuários.

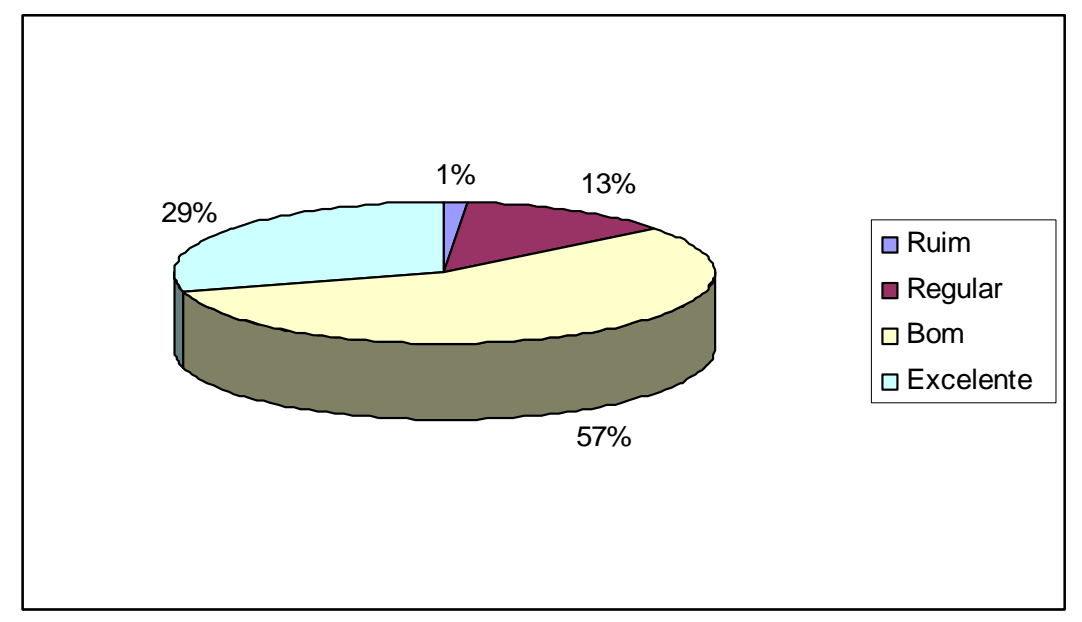

Gráfico 11: Satisfação com relação à qualidade do conteúdo da BDJur

Para identificar o perfil dos usuários que responderam "Regular" e "Ruim", fezse um cruzamento entre essas respostas e o cargo dos respondentes.

Depreende-se do gráfico 12 que grande parte, ou 71 respondentes que estão insatisfeitos com a qualidade do conteúdo da BDJur são usuários externos, que não têm nenhum vínculo trabalhista com o STJ. Uma provável justificativa para esse fenômeno pode ser o conteúdo buscado por esses usuários, ou seja, eles procurarem documentos que vão de encontro com a política da Biblioteca. 


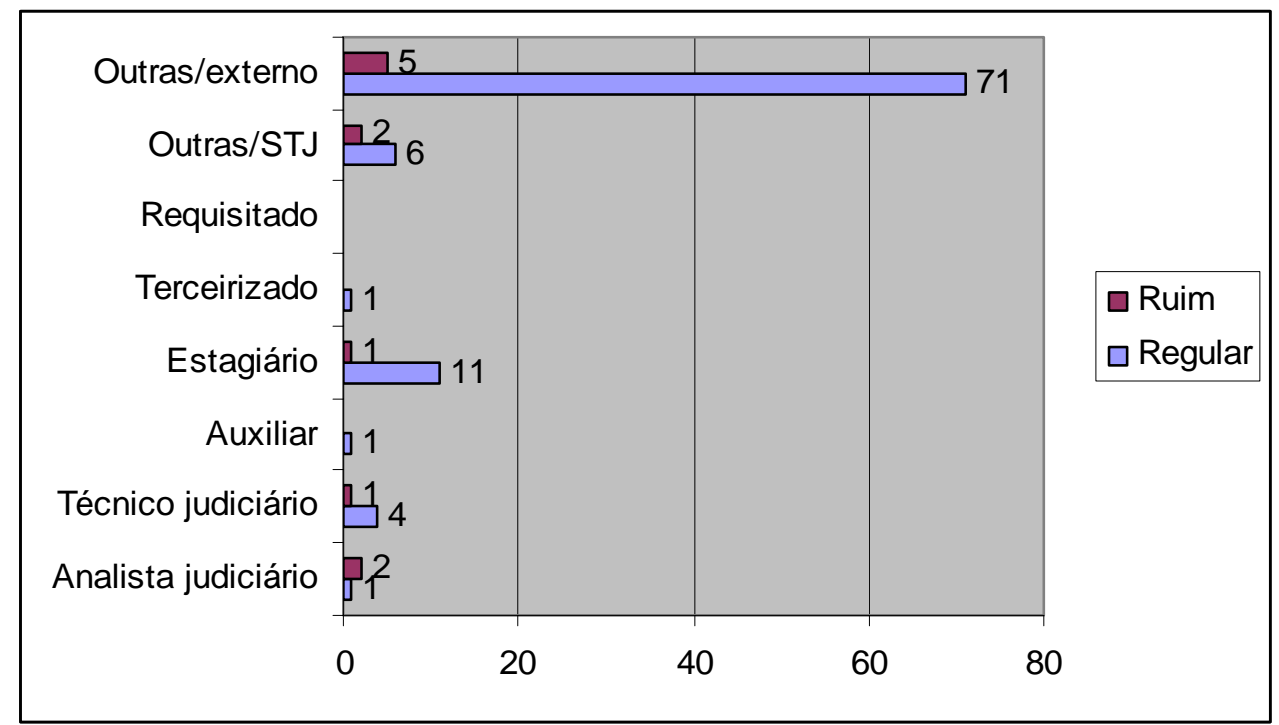

Gráfico 12: Cruzamento do cargo com a satisfação quanto à qualidade do conteúdo da BDJur

\section{Questão 12: Como avalia a Organização da ferramenta da BDJur?}

Outra tendência positiva é a organização da ferramenta da BDJur, conforme mostra o gráfico $13,73 \%$ dos usuários estão satisfeitos com esse item. É interessante notar que um usuário ao deparar-se com uma ferramenta difícil de usar e aprender, ele acaba desistindo da busca naquele momento e certamente não voltará a fazer pesquisa naquela biblioteca digital; nas palavras de Rosa (2004) "usabilidade é a facilidade de uso que as pessoas podem empregar uma ferramenta ou objeto a fim de realizar uma tarefa específica" e para evitar que um usuário fique confuso no momento da pesquisa, esse item precisa ser pensado no momento de planejamento da biblioteca. 


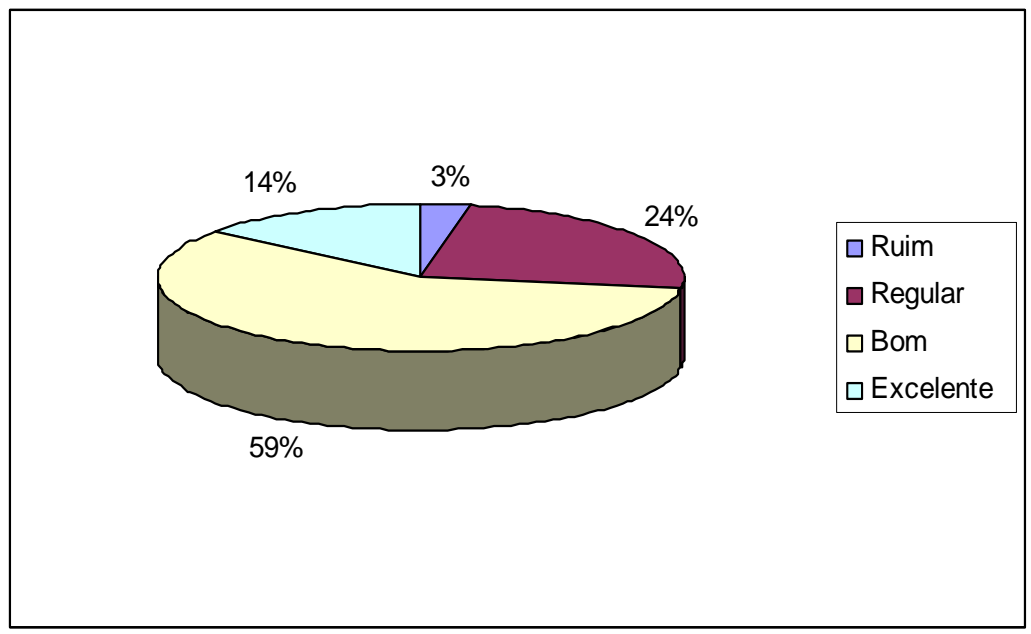

Gráfico 13: Satisfação com relação organização da ferramenta da BDJur

\section{3 - Como avalia a clareza dos objetivos das coleções da BDJur?}

Conforme mostra o gráfico $14,22 \%$ dos usuários estão insatisfeitos com a clareza dos objetivos das coleções da BDJur.

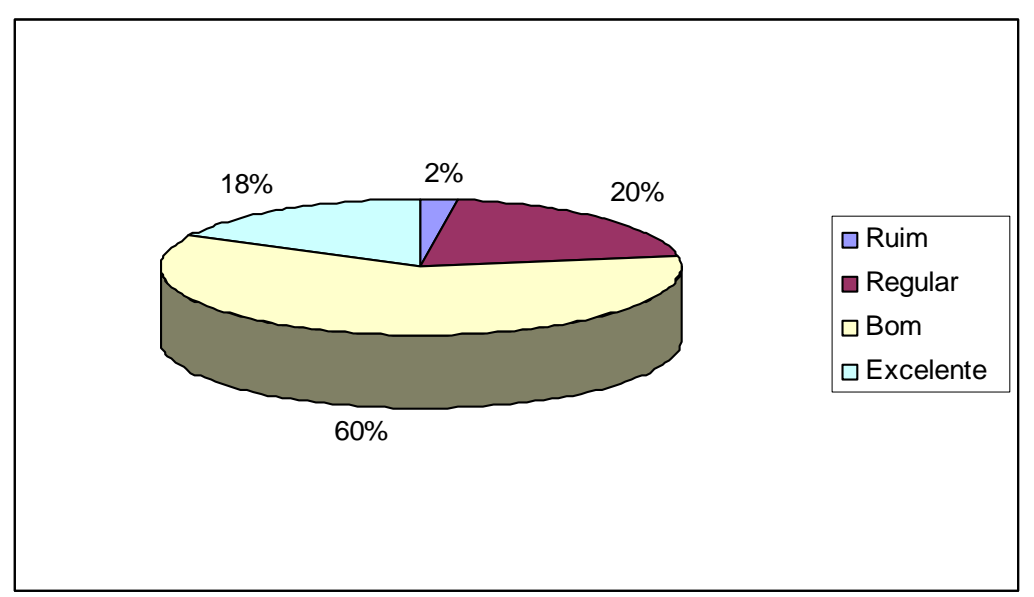

Gráfico 14: Satisfação com relação à clareza dos objetivos das coleções da BDJur

Para identificar quem são esses usuários fez-se o cruzamento entre esses respondentes e os seus respectivos cargos, se servidores/colaboradores do STJ, ou outros, no caso de usuários externos.

A tendência se repete no que aconteceu no cruzamento de satisfação quanto à qualidade do conteúdo da BDJur com o cargo do usuário, ou seja, são os usuários 
externos quem mais se posicionaram confusos com relação à clareza de objetivos das coleções da BDJur. É interessante ilustrar que a descrição de cada coleção pode ser verificada na página da BDJur - em uma lista disponível com as 20 coleções, ao se clicar em um nome, o usuário pode conferir uma nota explicativa do conteúdo da respectiva coleção.

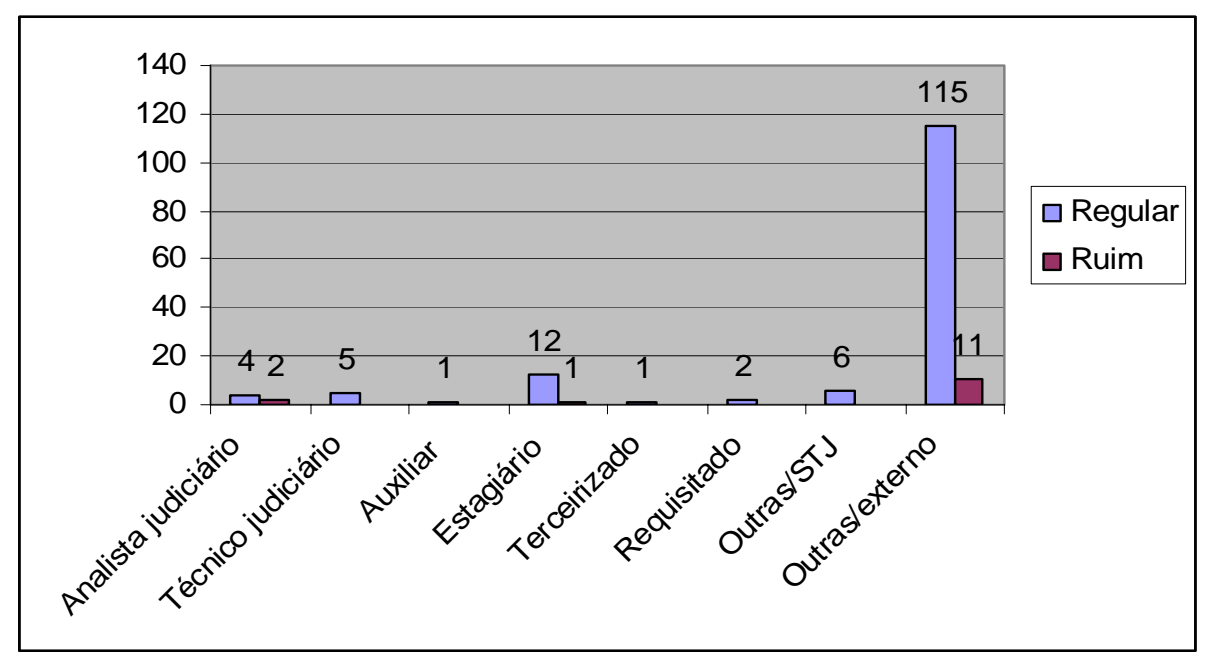

Gráfico 15: Cruzamento do cargo com a satisfação em relação à clareza dos objetivos das coleções da BDJur

\section{Questão 14: Como avalia o resultado de pesquisa da BDJur?}

Essa variável, resultado de pesquisa, é bastante importante no momento de uma busca. Para fazer buscas na BDJur, o usuário pode utilizar uma caixa de pesquisa localizada no topo da barra de navegação à direita na sua página inicial ou ainda, poderá limitar a pesquisa a uma determinada comunidade/sub-comunidade ou a uma coleção específica, para isso o usuário deverá escolher a opção "percorrer" comunidades e coleções localizada na barra de navegação à esquerda. A seguir deverá navegar até a comunidade/sub-comunidade ou coleção pretendida e utilizar a barra da pesquisa na respectiva página. A BDJur utiliza o mecanismo de 
pesquisa chamado Jakarta Lucene. Ao se fazer a pesquisa, as palavras que são introduzidas na caixa da pesquisa são automaticamente pesquisadas no inteiro teor do arquivo anexado e nos metadados dos documentos, como o título, nome do(s) autor(es), resumo, etc. O mecanismo de pesquisa ignora determinadas palavras, que são freqüentemente utilizadas na língua inglesa e portuguesa, mas que são ignoradas quando efetuadas uma pesquisa, por exemplo: a, and, are, be, but, by, for, ainda, ao, como, de, e, isso, logo, mas, na, uma, etc, além de sinais diacríticos como cedilha e acentos. O sistema permite ainda utilizar os mecanismos de truncagem e operadores booleanos. Na pesquisa avançada é possível restringir a comunidade/sub-comunidade e coleção na qual se pretende efetuar a busca. A BDJur, por usar o sistema web de pesquisa, acaba trazendo muita informação irrelevante no momento de uma pesquisa.

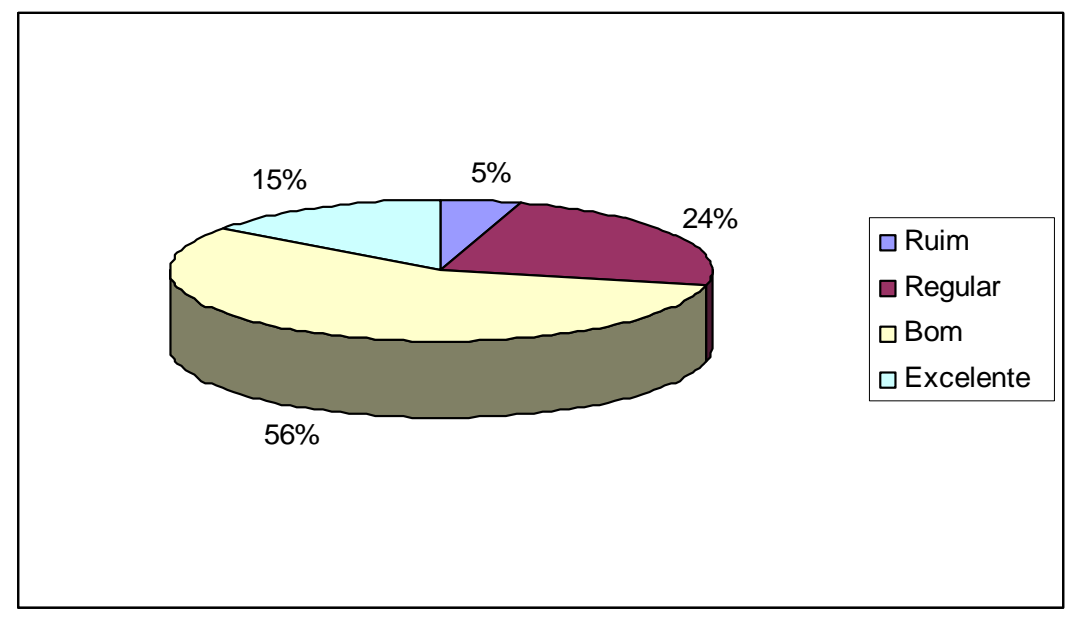

Gráfico 16: Satisfação com relação resultado de pesquisa da BDJur

Foi feito o cruzamento entre o cargo do usuário que respondeu "Regular" e "Ruim" com a satisfação em relação ao resultado de pesquisa da BDJur e o fenômeno que aconteceu nos cruzamentos anteriores, se repete aqui. Ficou evidente que a grande maioria dos respondentes insatisfeitos são usuários externos, 
percebe-se de acordo com o gráfico 17 , que os respondentes do STJ estão bem mais satisfeitos com relação ao resultado da pesquisa. Uma das alternativas consideradas seria a expectativa com relação ao tipo de documento que esses usuários esperam encontrar; supõe-se que as pessoas do Tribunal sabem o que encontrar nas suas pesquisas e por isso o resultado de suas buscas são menos frustrantes. Isso é apenas uma hipótese plausiva.

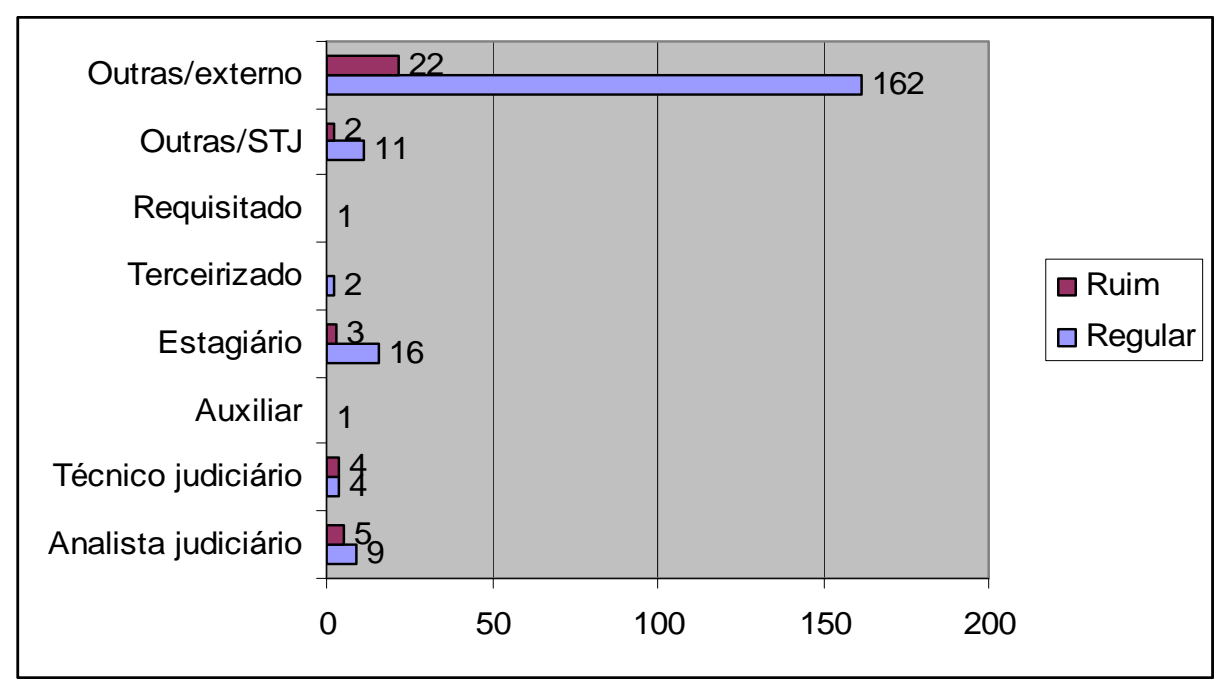

Gráfico 17: Cruzamento do cargo com a satisfação em relação ao resultado de pesquisa da BDJur

Ainda fazendo parte desse módulo a última questão indagada foi:

\section{Questão 15: De uma maneira geral, que nota atribuiria à BDJur?}

Conforme ficou constatado todos os itens pesquisados tiveram resultados positivos e $84 \%$ dos respondentes se disseram satisfeitos, de uma maneira geral, com relação à BDJur. É um índice altíssimo e as reclamações/sugestões elaboradas na questão aberta que pedia a opinião dos respondentes para melhorias na Biblioteca não significa necessariamente que os usuários estejam insatisfeitos, eles podem estar satisfeitos e dar sugestões para melhorias. 


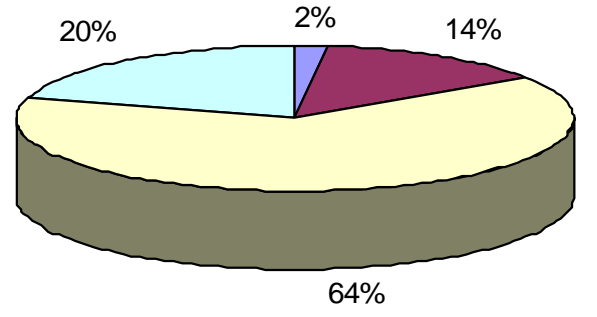

Gráfico 18: Satisfação em relação à BDJur de uma maneira geral

Assim, para identificar quem são os respondentes insatisfeitos com a BDJur, foi feito o cruzamento entre esses usuários e os seus respectivos cargos e o resultado comprova, assim como em todos os itens anteriores e conforme o gráfico 19, que a grande maioria (ou 71 respondentes insatisfeitos) são usuários externos.

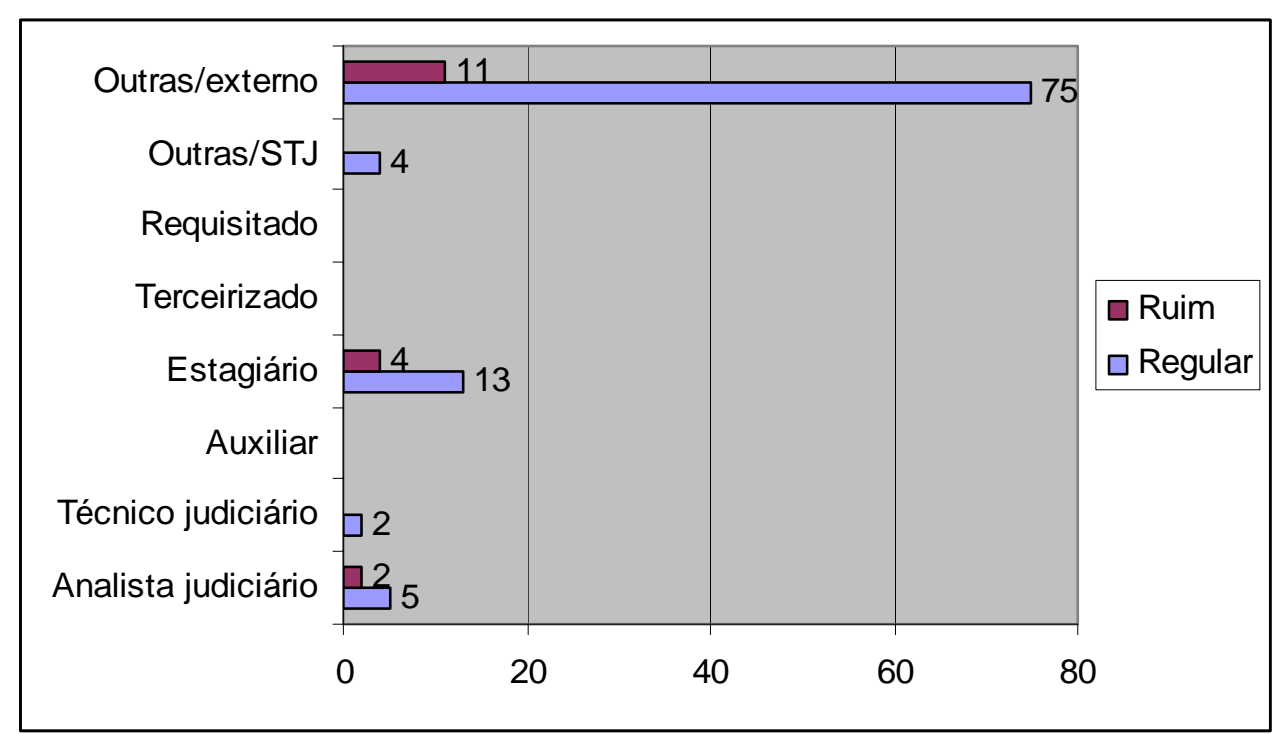

Gráfico 19: Cruzamento do cargo com a satisfação em relação à BDJurl 


\section{Questão 16: O que sugeriria para melhorar os serviços oferecidos pela}

\section{BDJur?}

A última pergunta dessa parte do questionário era uma questão aberta onde o usuário deveria fazer sugestões de melhorias para a BDJur. Muitos respondentes acabaram usando o espaço para expor suas dúvidas com relação a restrições em determinadas coleções e essa questão foi a prevalecente; muitos usuários reclamaram por não ter acesso a alguns documentos e sugeriram que ele fosse irrestrito; outra questão bastante citada foram dúvidas e problemas com o cadastrado na Biblioteca; tiveram muitas sugestões de mais obras para pesquisa, alguns falaram em disponibilização de livro no seu inteiro teor; outra questão significativa sugerida foi a melhoria na ferramenta de pesquisa, interface e organização das coleções; alguns usuários se identificaram com dúvidas em relação à BDJur e esse problema foi constatado em várias respostas, ficando nítido a necessidade de maiores esclarecimentos sobre a BDJur; muitos reclamam do depósito do que chamam de "referência" ou "propaganda" de livros, certamente se referindo a "Coleção Sumários Jurídicos" que traz apenas o sumário de livros; alguns ainda reclamaram da falta de resposta para suas respectivas solicitações; um caso que chamou atenção foi a presença de um usuário com deficiência visual que sugeriu maior acessibilidade e reclamou de dificuldade encontrada para pesquisar na Biblioteca para esse tipo de usuário especial; vale citar ainda que houveram elogios, além de uma crítica ao questionário e sugestão para dar continuidade a pesquisa; por fim é importante ressaltar que tiveram muitos elogios ao conteúdo disponibilizado na BDJur e a sua equipe. Essas foram as sugestões que mais se destacaram, no entanto, vale salientar que tiveram muitas outras totalmente inviáveis e por isso não foram citadas. 
Como já relatado no início da metodologia, em função de limitações do Sistema de Pesquisa do STJ, o questionário foi dividido em duas partes para respostas, o que implicou em um "segundo" questionário. Essa parte que questionava a freqüência de consulta de cada coleção, portanto, foi analisada isoladamente e os resultados são apresentados a seguir:

\section{a) Acervo Fotográfico do STJ}

Quando 70\% dos respondentes dizem que nunca usaram o acervo fotográfico é certo afirmar que a coleção é desconhecida e causa pouco interesse aos usuários da Biblioteca. Essa coleção traz o acervo histórico do STJ em fotos e foi sugestão de Ministro da Casa.

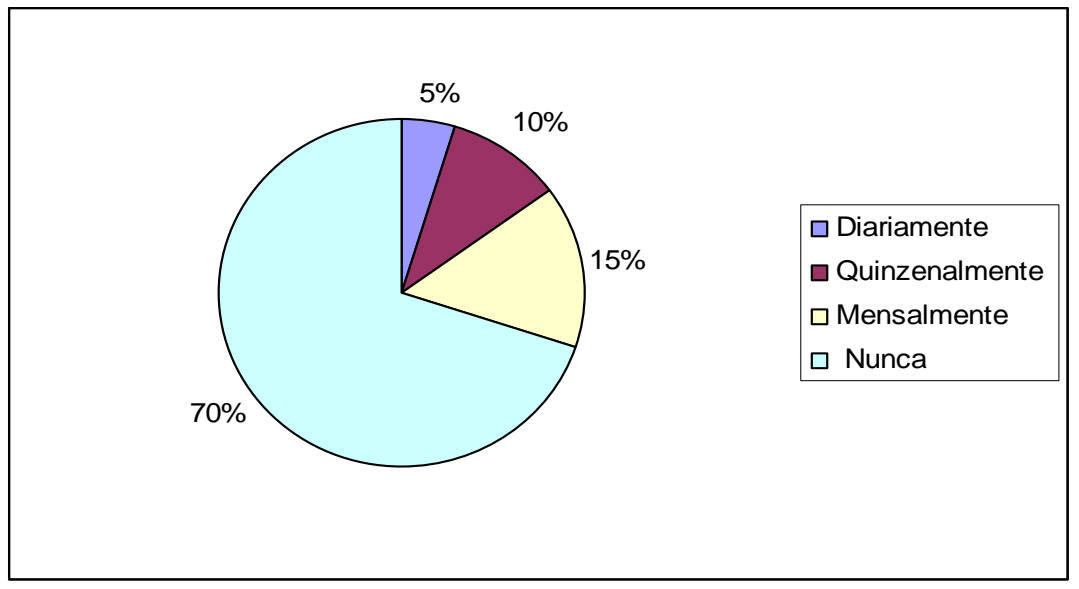

Gráfico 20: Freqüência de uso da coleção "Acervo fotográfico"

\section{b) Atos Normativos}

Há um interesse considerável, por partes dos respondentes, considerando que $34 \%$ dos usuários consultam, diária ou quinzenalmente essa coleção. É importante ressaltar que essa é a coleção com maior número de documentos, com mais de 3.300 itens, e por ser a coleção de atos normativos do STJ e da Presidência da República (que nomeiam Ministros do STJ), todos os dias são inseridos novos itens. 


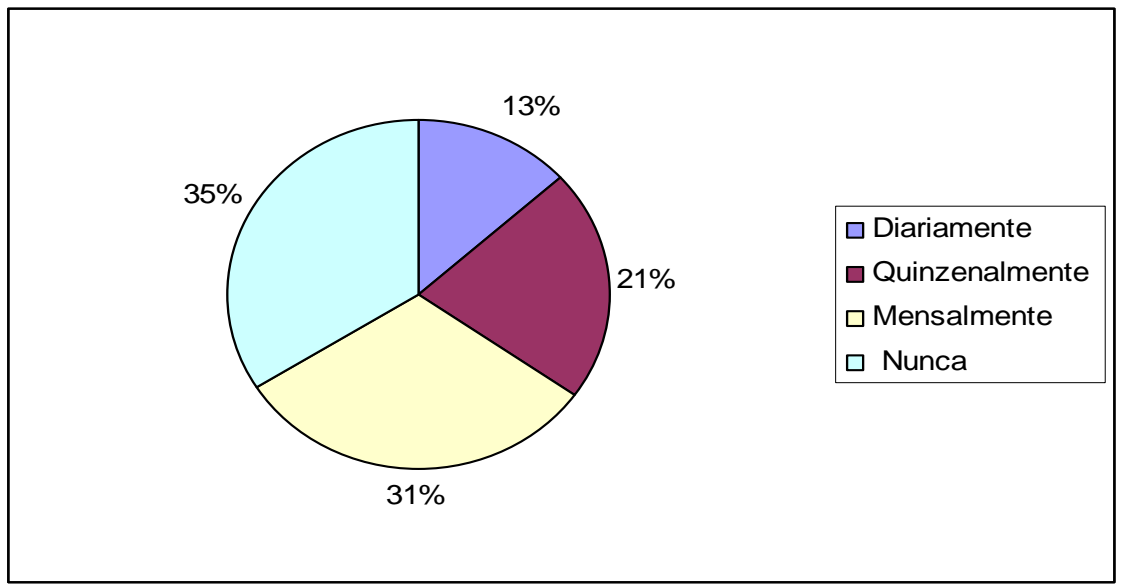

Gráfico 21: Freqüência de uso da coleção "Atos Normativos"

\section{c) Coletânea de Julgados e Momentos Jurídicos dos Magistrados no TFR e STJ}

É surpreendente a consulta diária de 18\% dos usuários nessa coleção, isso porque na prática essa coleção não existe, ou seja, constava até maio de 2007, período que foi realizada essa pesquisa, que não existia nenhum documento inserido nessa coleção. Deduzi-se que o usuário ao responder essa questão não se ateve ao nome da coleção e acabou por dar uma resposta incompatível com a sua realidade de freqüência de consulta. 


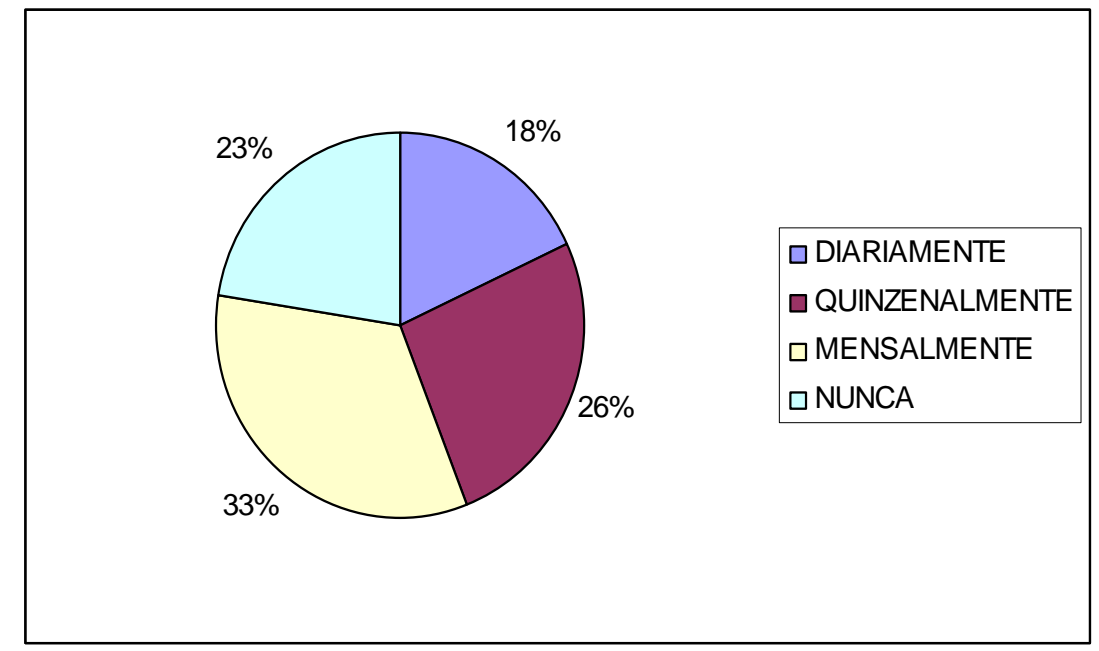

Gráfico 22: Freqüência de uso da coleção "Coletânea de Julgados e Momentos Jurídicos dos Magistrados no TFR e STJ"

\section{d) Documentos sobre a BDJur do STJ}

Por ser uma coleção que engloba os manuais de alimentação, políticas, apresentações e outros documentos que orientam o trabalho da Seção de Informação Digital, acaba sendo importante somente para a equipe que trabalha na Biblioteca e outros usuários que tenham interesse no projeto, o que provavelmente, não é exatamente o conteúdo que os usuários da BDJur busca. Isso não explica totalmente a freqüência de $17 \%$ de consulta diária nessa coleção.

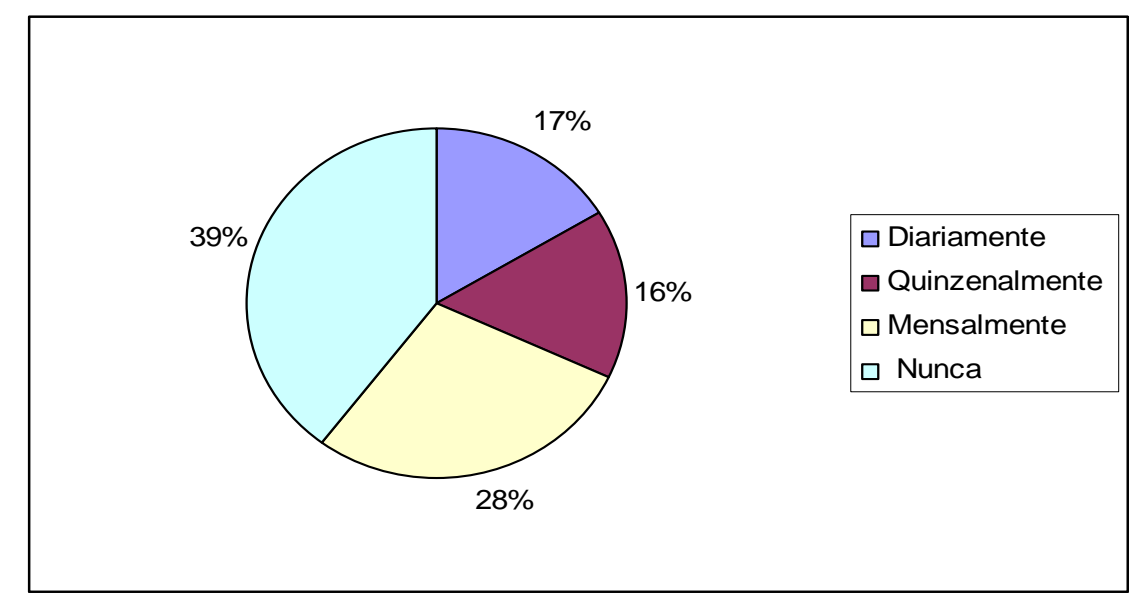

Gráfico 23: Freqüência de uso da coleção "Documentos sobre a BDJur do STJ" 


\section{e) Documentos Administrativos do STJ}

Apesar de ser uma coleção de amplo interesse público por se tratar da produção administrativa do STJ, o baixo índice de 7\% de consulta diária implica na quantidade de documentos que essa coleção dispõe, apenas 11 itens no total.

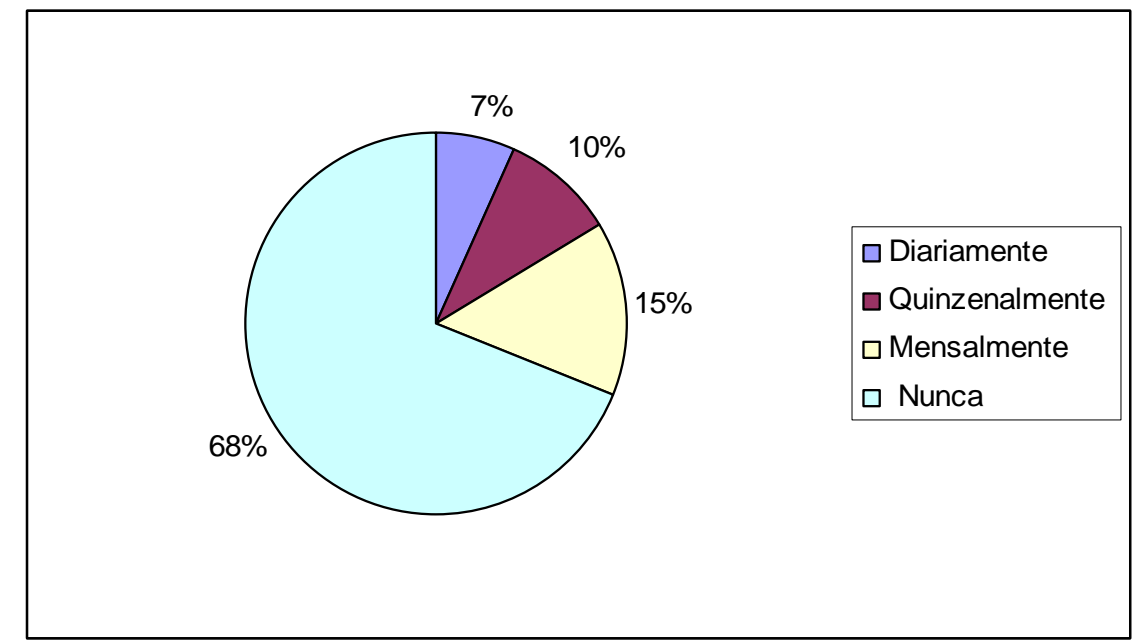

Gráfico 24: Freqüência de uso da coleção "Documentos Administrativo do STJ"

\section{f) Documentos Jurídicos}

Essa coleção, certamente, é a mais diversificada de todas por englobar os mais diversos autores e documentos da área jurídica. A freqüência de uso é significativa e provavelmente aumentaria em função de um número maior de documentos, no momento da pesquisa contava com apenas 69 itens depositados. 


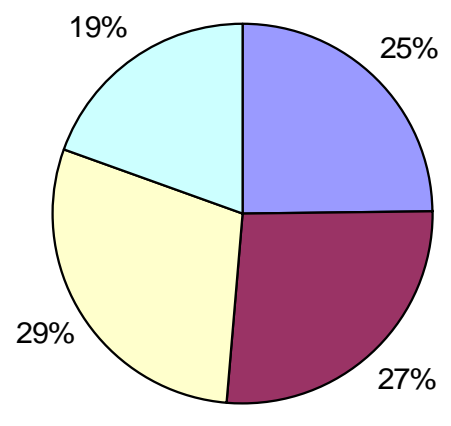

Gráfico 25: Freqüência de uso da coleção "Documentos Jurídicos"

\section{g) Escola Nacional de Formação e Aperfeiçoamento de Magistrados}

\section{- ENFAM}

A coleção registrou uma baixa freqüência de uso, conforme pode ser observado no gráfico 26, o que pode ser justificado pelo o conteúdo da coleção: são documentos de subsídio à implantação e às atividades da ENFAM, ou seja, apenas os Magistrados que freqüentam a Escola teria interesse nesses documentos. E ainda conta com o agravante que a coleção dispunha de apenas um item, até maio de 2007. 


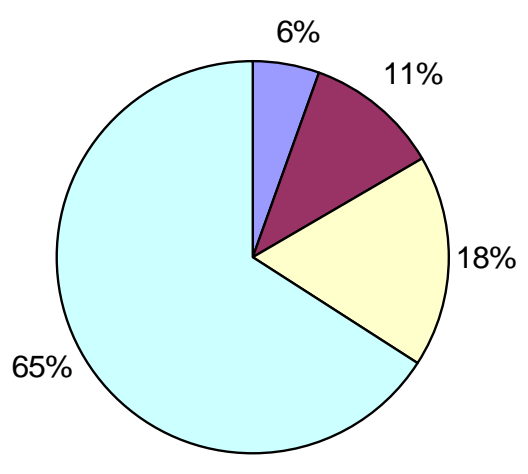

$\square$ DIARIAMENTE

$\square$ QUINZENALMENTE $\square$ MENSALMENTE

$\square$ NUNCA

Gráfico 26: Freqüência de uso da coleção "Escola Nacional de Formação e Aperfeiçoamento de Magistrados - ENFAM"

\section{h) Eventos do STJ}

Mais uma coleção com pouco conteúdo disponível, somente um documento. A mesma se destina a divulgar o material produzido nos eventos promovidos pelo STJ, mas não está atualizada e isso, em parte, justifica o percentual de $57 \%$ dos respondentes nunca terem acessado-a.

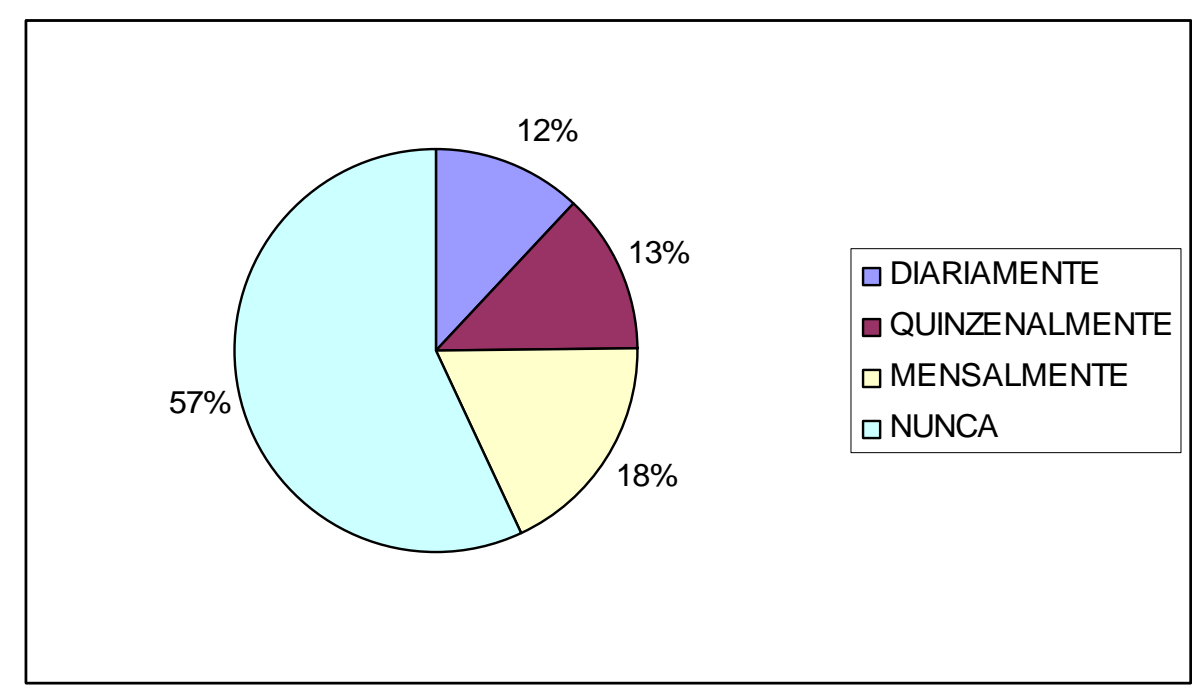

Gráfico 27: Freqüência de uso da coleção "Eventos do STJ" 


\section{i) Grupos de Pesquisa da CAPES}

O baixo índice de freqüência de consulta se repete nessa coleção que contava com 17 itens até o momento da pesquisa. Conforme mostra o gráfico 26, $86 \%$ dos respondentes nunca acessaram ou apenas consultam mensalmente seus documentos.

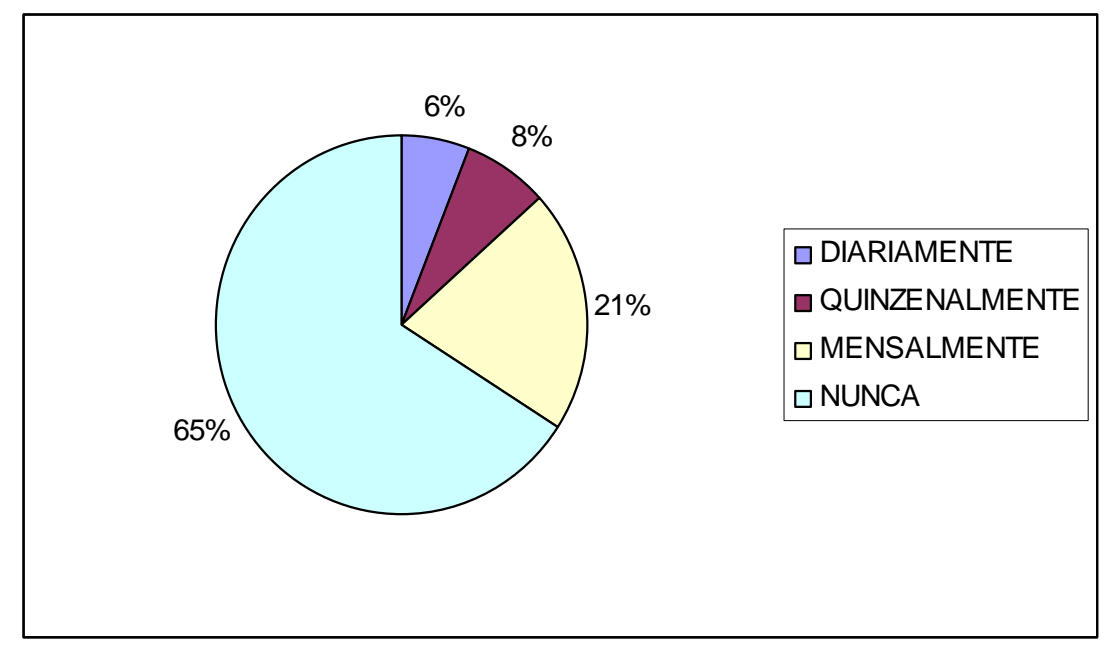

Gráfico 28: Freqüência de uso da coleção "Grupos de Pesquisa da CAPES"

\section{j) Jurisprudência do STJ}

Uma das freqüências de consulta que mais surpreendeu em função do alto índice, $48 \%$ dos usuários disseram acessar diariamente a coleção quando a mesma está em testes e conta com apenas 3 documentos. Provavelmente os usuários

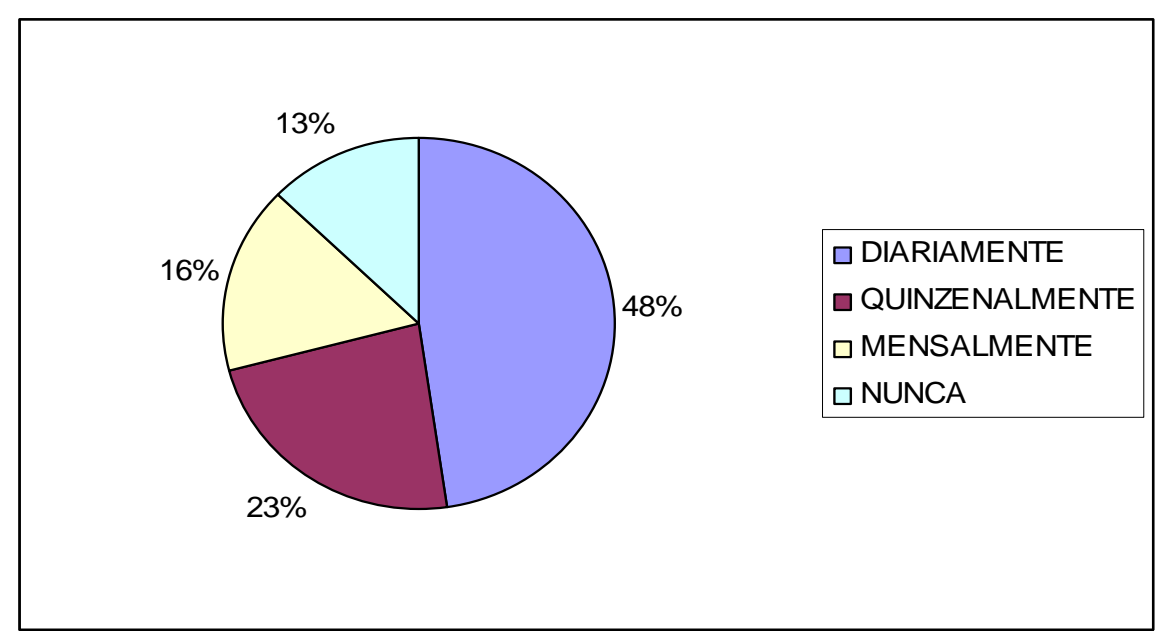

Gráfico 29: Freqüência de uso da coleção "Jurisprudência do STJ" 


\section{k) Laboratório de Conservação e Restauração de Documentos - LACOR}

Por se tratar de estudos sobre conservação e restauração de documentos, elaborados pelo LACOR, essa coleção que é mantida pelo Laboratório de Conservação e Restauração de Documentos do STJ, interessa apenas àquele setor e não deveria fazer parte da BDJur, isso explica o pouco interesse nessa coleção: quase $80 \%$ dos respondentes nunca acessaram seu conteúdo que tinha quatro documentos inseridos até a realização desta pesquisa.

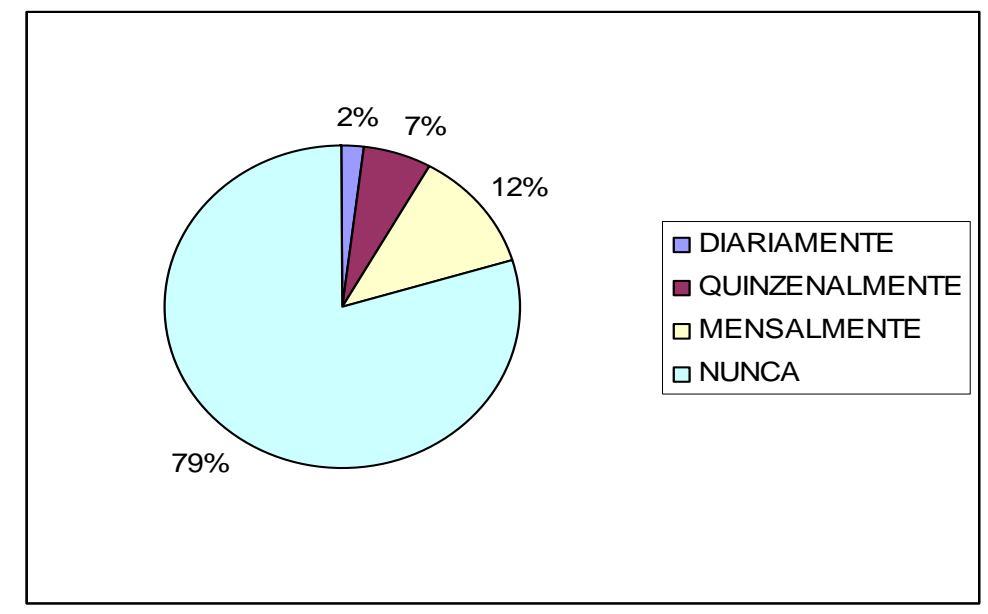

Gráfico 30: Freqüência de uso da coleção "Laboratório de Conservação e Restauração de Documentos - LACOR"

\section{l) Links Jurídicos}

Apesar de o seu objetivo ser facilitar o acesso a sites de interesse na área jurídica, com a indicação dos seus conteúdos, essa coleção direciona a links quebrados, desatualizados, ou seja, a coleção está desatualizada no todo, muito embora cerca de $44 \%$ dos respondentes disseram acessar o conteúdo da coleção pelo o menos a cada 15 dias. 


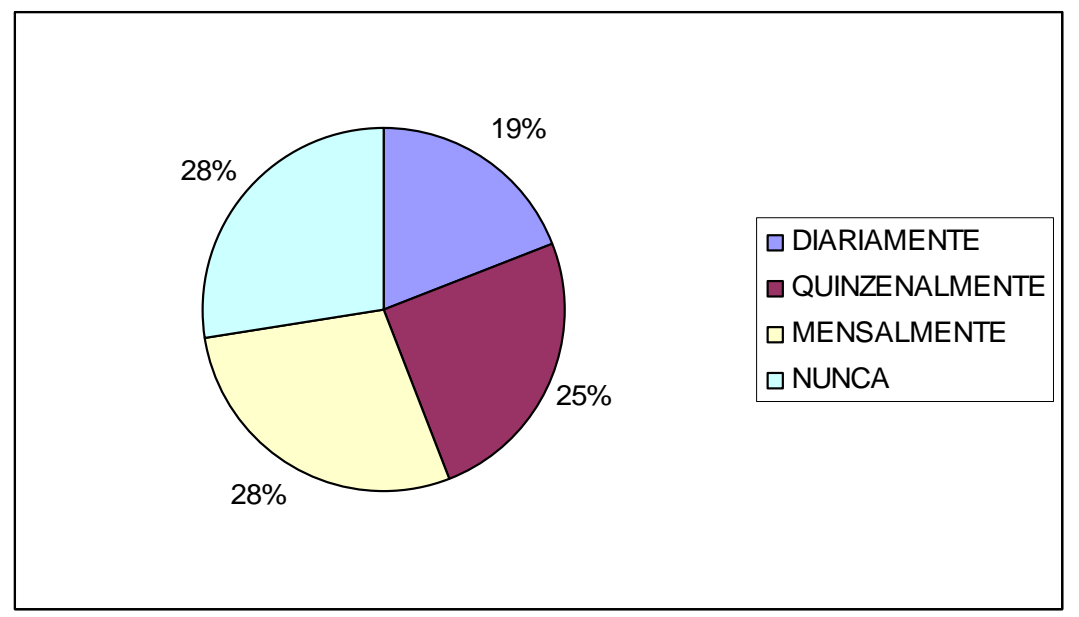

Gráfico 31: Freqüência de uso da coleção "Links Jurídicos"

\section{m) Obras Raras}

O STJ acabara de digitalizar seu acervo de obras raras e passava, no momento da pesquisa, pelo o processo de formatação desses documentos, portanto não existia nenhum item nessa coleção, o que justifica a retirada da mesma até que o conteúdo desses documentos estivessem disponíveis. Mais uma vez, a hipótese de que os usuários responderam essa questão sem se dar conta exatamente de qual coleção estava sendo investigada, é levantada. Caso contrário, seria inviável o acesso, ainda que mensalmente, de mais de $40 \%$ dos respondentes.

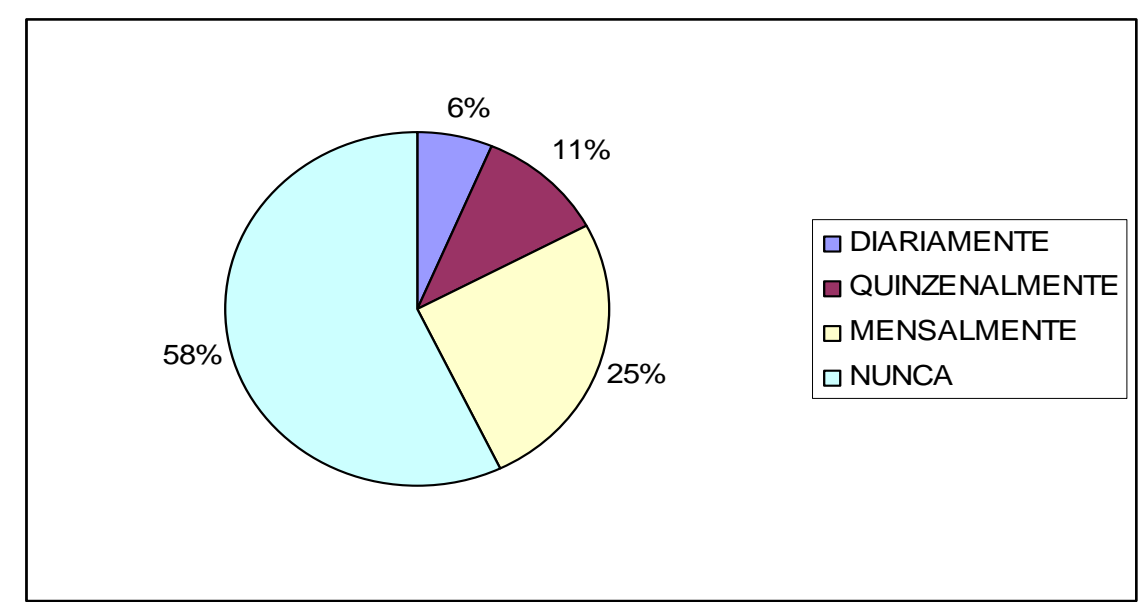

Gráfico 32: Freqüência de uso da coleção "Obras Raras"

n) Pesquisa Jurídicas 
Com certeza essa é a coleção que mais causa frustração aos usuários, isso porque, como é explicado na sua respectiva página, em respeito à lei de direitos autorais os conteúdos desta coleção são de visualização restrita. Caso seja interesse do usuário visualizar além do que está disponibilizado nos metadados, ele terá que entrar em contato com a Seção de Pesquisa da Biblioteca Ministro Oscar Saraiva. Infere-se que por ignorar essa restrição, muitos usuários fazem menção, na questão aberta do questionário onde deveriam sugerir melhorias à BDJur, à questão da disponibilização de inteiro teor dos documentos.

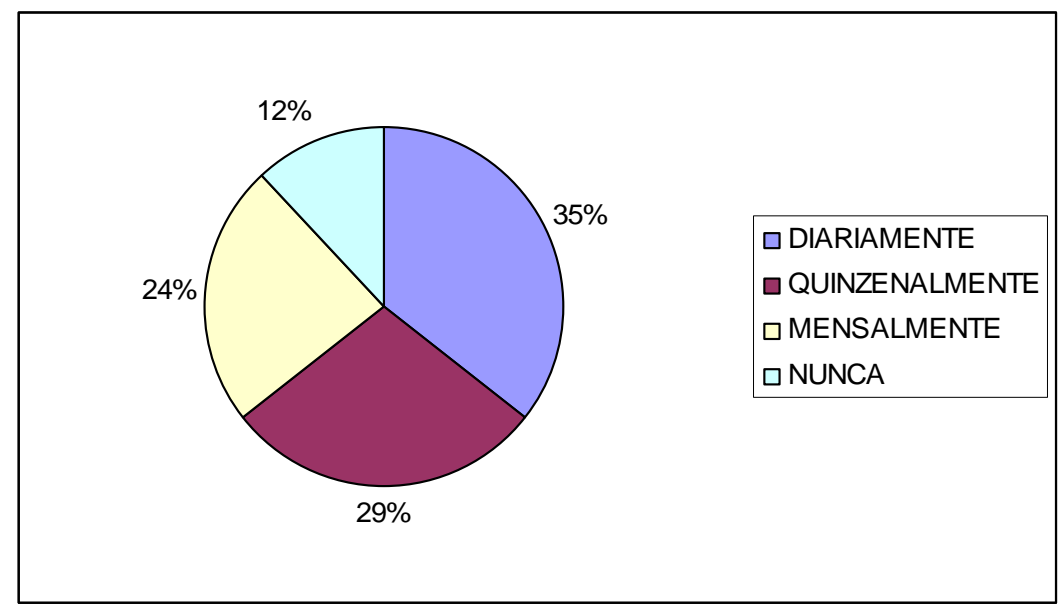

Gráfico 33: Freqüência de uso da coleção "Pesquisa Jurídica"

\section{o) Produção Intelectual dos Ministros do STJ}

O alto índice de freqüência de consulta na coleção, de acordo com o gráfico 32, demonstra o grau o interesse por parte dos usuários nessa coleção que tem o segundo maior número de documentos, com mais 1.140 itens até o momento da pesquisa. A importância da coleção é dada por seu objetivo, como o próprio nome indica: reúne, preserva e difunde a produção intelectual dos Ministros do STJ, tanto os em atividade como os aposentados. São inseridos documentos diariamente nessa coleção e sem dúvida seu conteúdo é de excelente qualidade, haja vista que 
quem os produz são magistrados renomados e bem letrados. A surpresa aqui é a presença de $12 \%$ dos usuários responderem que nunca acessaram a coleção.

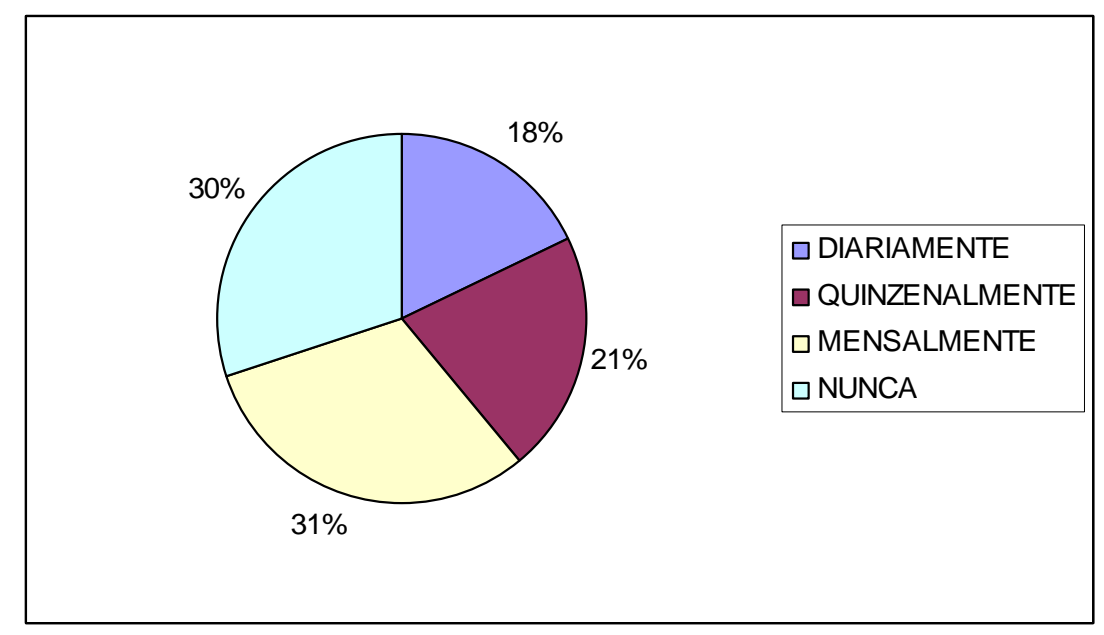

Gráfico 34: Freqüência de uso da coleção "Produção Intelectual dos Ministros do STJ"

\section{p) Sumários Jurídicos}

Não se pode afirmar que a freqüência de uso da coleção "Sumários Jurídicos", $15 \%$ diariamente e $27 \%$ mensalmente conforme o gráfico 35 , se deve propriamente à função dessa coleção; isso porque essa é a segunda coleção que mais causa frustração ao usuário, explica-se: é comum a equipe da BDJur atender reclamações com relação ao teor dessa coleção, isso porque o usuário encontra um sumário depois de fazer uma busca por um determinado autor, título ou assunto de um documento e como resposta de sua pesquisa, ele tem um documento que está nessa coleção, e no caso, desconhecendo a sua função que é divulgar os as obras recentemente incorporadas ao acervo da Biblioteca Ministro Oscar Saraiva, do STJ, esse usuário fica esperando aparecer o livro inteiro. Às vezes, por falta de conhecimento da lei de direitos autorais que não permite disponibilização de monografias no todo, o usuário deseja encontrar um livro inteiramente digitalizado ao seu alcance, para numa seqüência de comandos, baixar a obra completa. Com a 
sua expectativa totalmente desfeita, esses usuários criticam a coleção e chegam a achar que a função de uma biblioteca digital não é fazer "propagandas" de livros que têm em uma biblioteca tradicional a qual está relacionada. A coleção existe para outra função e, salvo essas exceções, ela é importante para direcionar a leitura completa ou não de livro inteiro. Essa é a verdadeira função dessa coleção que, na maioria das vezes, é desconhecida e por isso mal interpretada.

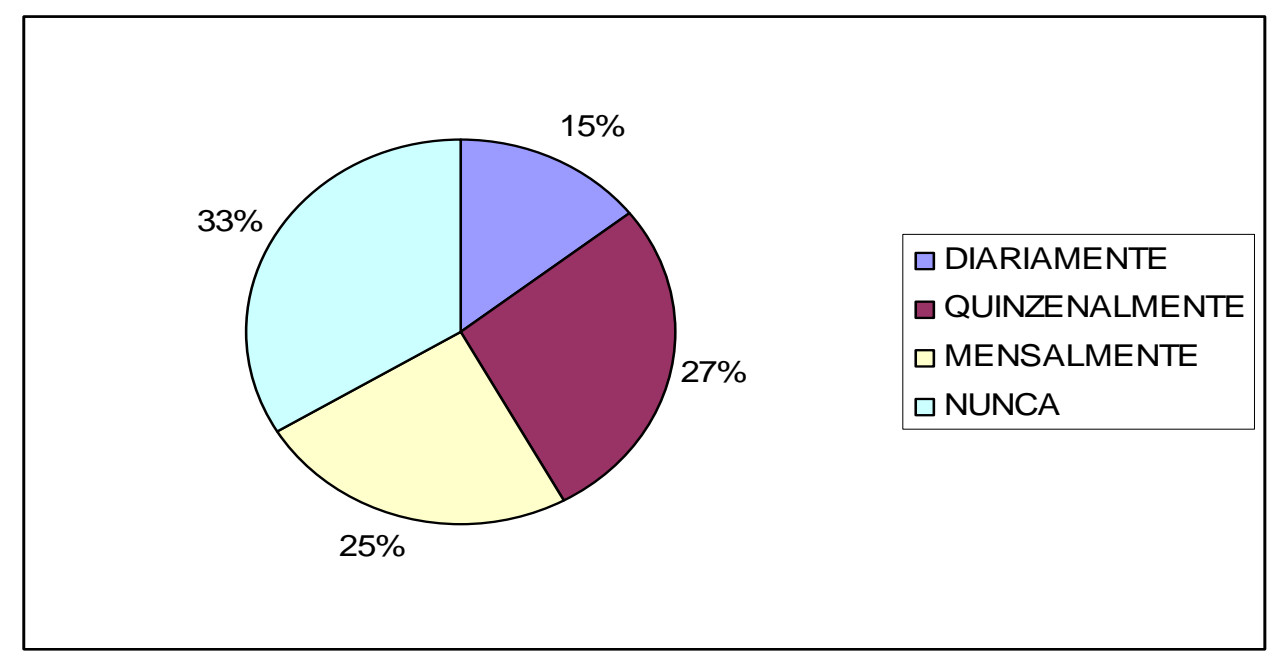

Gráfico 35: Freqüência de uso da coleção "Sumários Jurídicos"

\section{q) Tecnologia de BDJUR}

Coleção com poucos documentos, quatro no total, e por se tratar de versões e extensões do programa utilizado pela BDJur, criadas com o objetivo de customizar o software às necessidades particulares das coleções da BDJur do STJ, como a nota explicativa infere não é de interesse do usuário da Biblioteca propriamente dito e essa razão explica o alto percentual, segundo o gráfico 34 , de $70 \%$ dos respondentes nunca terem acessado essa coleção. Esta coleção traz o pacote de programas necessários para a criação de uma biblioteca digital. Acompanha o manual de instalação para o pessoal da área técnica. 


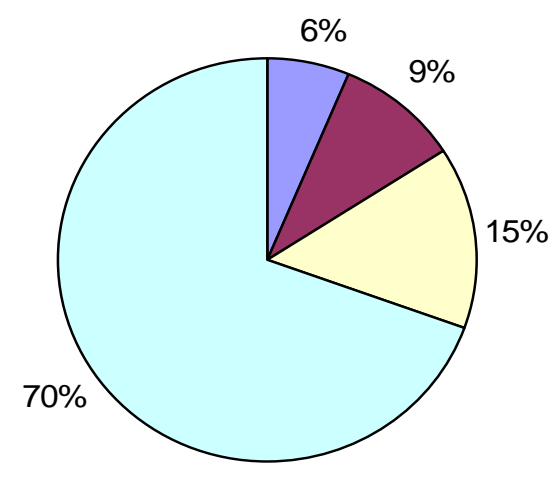

$\square$ DIARIAMENTE

$\square$ QUINZENALMENTE

$\square$ MENSALMENTE

$\square$ NUNCA

Gráfico 36: Freqüência de uso da coleção "Tecnologia da BDJur"

\section{r) Teses e Dissertações}

As duas próximas coleções - Teses e Dissertações e Trabalhos de Conclusões de Curso e Monografias - poderiam, sem causar prejuízo algum, ser reduzidas a uma apenas. O critério de separação das duas coleções, seria que os trabalhos de conclusão de curso e as monografias não têm critérios tão rigorosos para aprovação quanto as teses e dissertações. Os números de documentos dessas coleções somam 20 no total e por se tratar de conteúdos semelhantes apresentam freqüência semelhante de consulta.

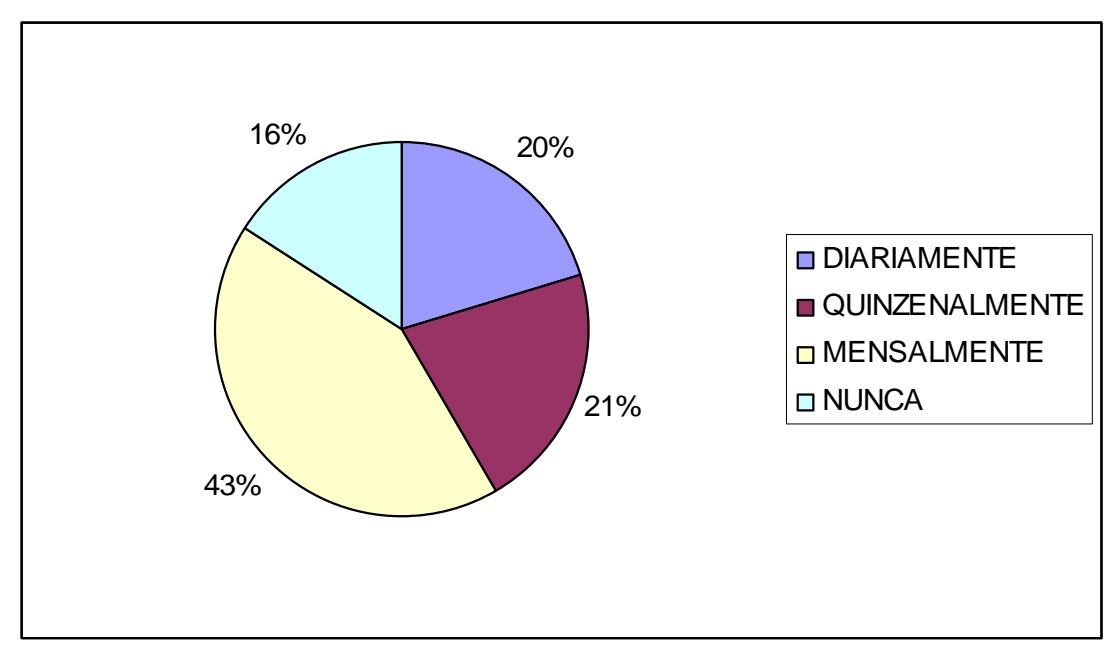

Gráfico 37: Freqüência de uso da coleção "Teses e Dissertações" 


\section{s) Trabalhos de Conclusões de Curso e Monografias}

Conforme relatado na coleção anterior e pode ser observado no gráfico 38, a freqüência de consulta nesses documentos é baixa, se considerando que $25 \%$ dos usuários nunca acessaram seu conteúdo. Entretanto a consulta diária registrada ainda é alta e não condiz com o seu pouco número de documentos: 12 até o momento da realização da pesquisa.

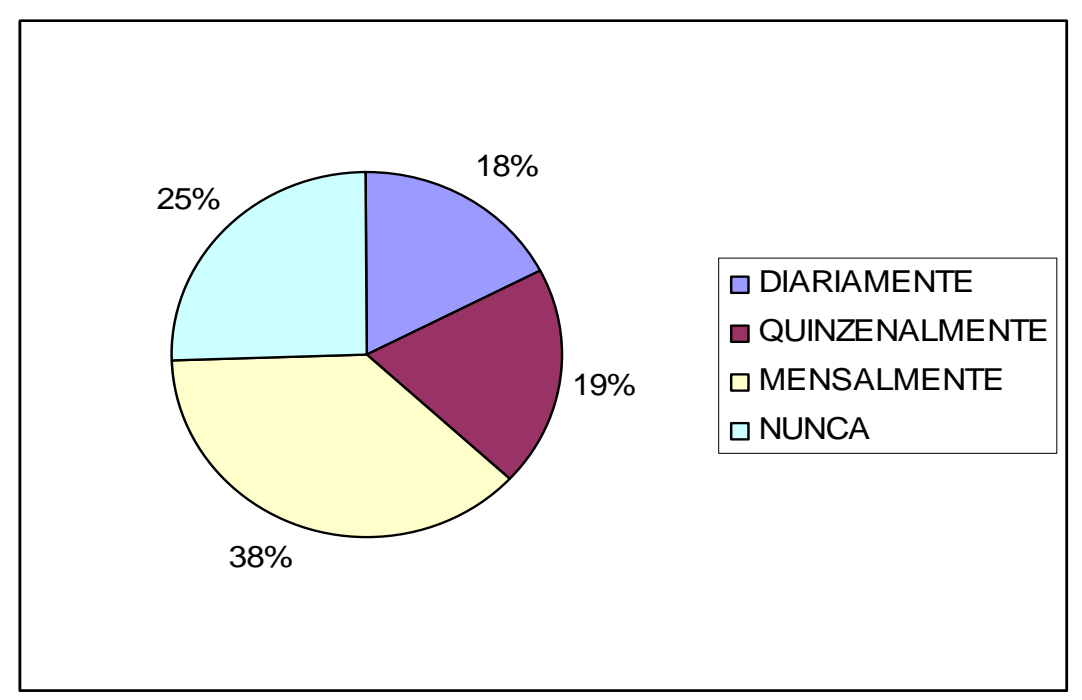

Gráfico 38: Freqüência de uso da coleção "Trabalhos de Conclusões de Curso e Monografias" 


\section{CONCLUSÃO}

Com a evolução das tecnologias, a globalização e o acesso à informação sem fronteiras proporcionado por meio da Internet, houve uma mudança significativa na maneira como os sistemas de informação estão sendo criados, administrados e utilizados.

As bibliotecas, especificamente, estão incorporando novas políticas de desenvolvimento de suas coleções e disponibilizando novos produtos e serviços de informação na Internet.

As bibliotecas digitais constituem um importante meio de promover o acesso aos recursos informacionais, que são essenciais para o desenvolvimento e a melhoria de vida das pessoas. E a BDJur, especificamente, propicia aos profissionais e estudantes da área jurídica acesso à informação produzida nesse campo do conhecimento. Concretiza, assim, o objetivo das bibliotecas digitais que é a democratização do acesso à informação.

A pesquisa atingiu o objetivo geral que era verificar se as informações disponibilizadas na BDJur atendem as necessidades de informação de seus usuários. Com um percentual de $84 \%$ de aprovação, considerando como parâmetros de satisfação, as repostas "Bom" e "Excelente", a Biblioteca atende de maneira satisfatória a necessidade de informação dos seus usuários.

Foi verificado que o grau de formação dos usuários da BDJur é bastante elevado, se destacando o número de graduados com 46\%, seguido de especializações com 33\%. Também foi verificado que a maior parte, ou $55,17 \%$ dos usuários não têm qualquer vínculo trabalhista com o STJ. Dentre os usuários internos os que se destacam são os estagiários com $8,56 \%$, seguido de analistas judiciário com 5,87\%. O tempo médio de uso da BDJur é de um a seis meses. 
É importante ressaltar que serviços, como o "Alerta por e-mail", que informa sobre novos depósitos na coleção que o usuário pode escolher de acordo com o seu interesse, é pouco utilizado; apenas $17,37 \%$ dos respondentes declarou ser cadastrado nesse serviço.

No que diz respeito ao atendimento de suas respectivas solicitações, $62 \%$ dos usuários declaram que foram atendidos nos seus pedidos, destacando que a maioria dos casos não atendidos são de usuários externos.

Quanto à satisfação dos usuários com relação a itens como layout, interface de pesquisa, organização das coleções e da ferramenta, qualidade do conteúdo, clareza dos objetivos das coleções e o resultado de pesquisa tiveram um percentual de satisfação, considerando as respostas "Excelente" e "Bom" como parâmetros de satisfação, com mais de $70 \%$ de aprovação.

A maior dificuldade constatada, por parte do usuário, é fazer o cadastramento e saber quais coleções têm restrições de acesso.

No que se refere à freqüência de consulta de determinadas coleções, verificou-se que muitas, entre elas a coleção de Acervo Fotográfico do STJ, a de Documentos Administrativos do STJ, a da Escola Nacional de Formação e Aperfeiçoamento de Magistrados (ENFAM), a de Grupos de Pesquisa da CAPES, a do Laboratório de Conservação e Restauração de Documentos (LACOR) e a de Tecnologia de BDJUR, tiveram um índice superior a $60 \%$ de usuários que nunca acessaram essas coleções, em algumas, esse índice chega a mais de $70 \%$ o que conclui que essas coleções são de pouco interesse ou desconhecida pela a maioria dos usuários. Um outro ponto observado e que pode justificar o baixo uso dessas coleções é a sua presença apenas como mais uma coleção, ou seja, apesar da coleção existir não tinha nenhum documento inserido até o momento da pesquisa, é 
o caso da coleção "Coletânea de Julgados e Momentos Jurídicos dos Magistrados no TFR e STJ" e "Obras Raras". Em outras ainda, foi verificado que contava com apenas um item, a exemplificar: "Eventos do STJ" e "Escola Nacional de Formação e Aperfeiçoamento de Magistrados - ENFAM".

A partir das sugestões feitas infere-se que há necessidade de um serviço de tira dúvidas para o usuário, que pode ser feita por e-mail, folhetos, eventos, entre outros meios de divulgação. Vale ressaltar que a Biblioteca já dispõe de um Frequently Asked Questions (FAQ).

Pode-se pensar em implementar processos de avaliação dos usuários em relação à prestação de serviços. Um processo contínuo de avaliação da BDJur poderá assegurar aos seus usuários a promoção de serviços voltados para a sua satisfação e, consequentemente, aumentará seu uso. Pode-se pensar também em uma maior divulgação da BDJur e na necessidade de treinamentos para os seus usuários para difundir, ampliar e otimizar o uso da Biblioteca.

Partindo do pressuposto que um sistema de informação deverá existir para ser utilizado, é fundamental pensar em promover a satisfação dos usuários através da otimização da prestação de seus serviços. E nesse momento emerge a necessidade de estudo de satisfação dos usuários da BDJur, o que justifica e assegura a importância de dar continuidade a esse trabalho.

A BDJur representa, indiscutivelmente, um avanço significativo da tecnologia, porém, apesar da constatação de satisfação da maioria de usuários e dos esforços de sua equipe, permanecem alguns desafios e obstáculos a serem vencidos. 


\section{REFERÊNCIA BIBLIOGRÁFICA}

ALENCAR, Anderson Fernandes de. Bibliotecas digitais: uma nova aproximação. Informação \& Sociedade: Estudos, v. 14, n. 1, 2004.

AMARAL, Sueli Angélica; SOUZA, K. M. Funções desempenhadas pelos sites de bibliotecas jurídicas governamentais brasileiras. In: CONGRESSO DE INICIAÇÃO CIENTÍFICA DA UNIVERSIDADE DE BRASÍLIA, 11., 2003, Brasília. Brasília: Universidade de Brasília, 2003. v. 9.

BOHMERWALD, Paula. Uma proposta metodológica para avaliação de bibliotecas digitais: usabilidade e comportamento de busca por informação na Biblioteca Digital da PUC - Minas. Ciência da Informação, Brasília, v. 34, n. 1, p. 95-103, jan./abr. 2005.

BORGMAN, Christine L. Usability of digital libraries in a multicultural environment. In: Design and usability of digital library: case studies in the Asia Pacific. Yin-Leng Theng and Schubert Foo (ed.). Hershey, London, Singapore: Information Science Publishing, 2004. 395 p.

CUNHA, Murilo Bastos da. Construindo o futuro: a biblioteca universitária brasileira em 2010. Ciência da Informação, Brasília, v. 29, n. 1, p. 71-89, jan./abr. 2000. Disponível em: <http://www.ibict.br/cionline/artigos/>. Acesso em: 17 mar. 2007.

- Desafios na construção de uma biblioteca digital. Ciência da Informação, Brasília, v. 28, n. 3, 1999. 12 p. Disponível em: <http:/www.ibict.br/cionline/viewarticle.php?id=323\&layout=abstract>. Acesso em: 13 fev. 2007.

; MCCARTHY, Cavan. Estado atual das bibliotecas digitais no Brasil. In: MARCONDES, Carlos H.; KURAMOTO, Hélio; TOUTAIN, Lídia Brandão; SAYÃO; Luís (orgs.). Bibliotecas digitais: saberes e práticas. Salvador/Brasília : UFBA/IBICT, 2005. p. 25- 53. 
DAVIS, Philip M; CONNOLLY, Matthew J. L. Institutional repositories: evaluating the reasons for non-use of Cornell University's installation of DSpace. D-Lib Magazine, v. 13, n. 3/4, mar./abr. 2007.

DIAS, Eduardo Wense. Contexto Digital e Tratamento da Informação. Ciência da Informação, Brasília, v. 2, n. 5, out. 2001. Disponível em: <http://www.dgz.org.br/out01/Art_01.htm>. Acesso em: 20 fev. 2007.

DRABENSTOTT, Karen M.; BURMAN, Celeste M. Revisão analítica da biblioteca do futuro. Ciência da Informação, Brasília, v. 26, n. 2, p. 180-194, mai./ago. 1997.

FERREIRA, José Rincon. A biblioteca digital. Disponível em: < http://www.ime.usp.br/ is/infousp/rincon/rincon.htm>. Acesso em: 12 mar. 2007.

KAFURE, Ivette; CUNHA, Murilo Bastos da. Usabilidade em bibliotecas digitais. In: CONFERÊNCIA IBEROAMERICANA DE PUBLICAÇÕES ELETRÔNICAS NO CONTEXTO DA COMUNICAÇÃO CIENTIFICA, 11., 2006, Universidade de Brasília, 25 a 28 de abril de 2006. Disponível em: http://portal.cid.unb.br/CIPECCbr/viewpaper.php?id=43. Acesso em: 1 maio 2007.

MACHADO, Maria Teresa Ferlini. Relacionamento Biblioteca/usuário: fator relevante no processo de disseminação da informação jurídica. In: Proceedings XIX Congresso Brasileiro de Biblioteconomia e Documentação 1, Centro de eventos da PUCRS. Disponível em: <http://dici.ibict.br/archive/00000777/01/T126.pdf>. Acesso em: 9 maio 2007.

MARCHIORI, Patricia Zeni. "Ciberteca" ou biblioteca virtual: uma perspectiva de gerenciamento de recursos de informação. Ciência da Informação. v. 26 n.2 Brasília maio/ago. $1997 . \quad$ Disponível em: <http://www.scielo.br/scielo.php?script=sci_arttext\&pid=S0100$19651997000200002>$. Acesso em: 1 maio 2007. 
OHIRA, Maria Lourdes Blatt; PRADO, Noêmia Schoffen. Bibliotecas virtuais e digitais: análise de artigos de periódicos brasileiros (1995/2000). Ciência da Informação, Brasília, v. 31, n. 1, p. 61-74, jan./abr. 2002.

PROCÓPIO, Ednei. Construindo uma biblioteca digital. São Paulo: El - Edições Inteligentes, 2004.

REZENDE, Ana Paula de; MACHADO, Valéria Maria. Centro de informação jurídica eletrônico e virtual. Ciência da Informação, Brasília, v. 29, n. 1, p. 51-60, jan./abr. 2000.

SARACEVIC, Tefko. Special issue on evaluation of digital libraries. Library Trends, v. 49, n. 2, dez. 2000, p. 350-369.

SILVEIRA, A. da. A usabilidade em catálogos on-line. Universidade do Rio de Janeiro, 2003. (Monografia em Biblioteconomia).

THENG, Yin-Leng. Quantitative and qualitative evaluations of the Singapore National Library Board's Digital Library. In: Design and usability of digital library: case studies in the Asia Pacific. Yin-Leng Theng and Schubert Foo (ed.). Hershey, London, Singapore: Information Science Publishing, 2004. 395 p.

Universidade do Minho de Portugal. Luso DSpace: portal sobre o DSpace para a comunidade de língua portuguesa. Disponível em: http://lusodspace.sdum.uminho.pt:8080/pt/dspace_about.jsp. Acesso: 9 maio 2007.

VILARINO, Elizabeth Gonçalves. Surgimento, implantação e gestão de bibliotecas virtuais: uma revisão de literatura, Perspectiva da Ciência da Informação, Belo Horizonte, v. 8, n. 1, p. 12-27, jan./jun. 2003. 
ANEXOS 


\section{Anexo A}

\section{E-mail enviado para os usuários cadastrados na BDJur}

Prezado Usuário,

A Equipe BDJur preparou uma pesquisa de opinião sobre nossos serviços.

Por meio de suas respostas poderemos aprimorar ainda mais a BDJur.

O questionário é composto de duas partes: a parte geral e a segunda, sobre a freqüência de consulta à cada coleção, de preenchimento opcional.

Colabore com nossa pesquisa acessando o endereço.

Observações: a equipe que disponibilizou a pesquisa no site da BDJur na internet e intranet, usando o Sistema de Pesquisa do STJ, optou por colocar o questionário em nome do Tribunal, por ser comum pesquisa desse tipo com relação a outros serviços. 


\section{Anexo B}

\section{Questionário}

1 - Grau de formação mais elevado:

Fundamental

Médio

Graduação

Especialização

Mestrado

Doutorado

2 - Qual o Seu cargo:

Analista Judiciário

Técnico Judiciário

Auxiliar

Estagiário

Terceirizado

Requisitado

Outros

Não Sou Servidor/Colaborador do STJ

3 - Qual sua profissão? (Caso não seja Servidor/Colaborador do STJ)

4 - Você utiliza a BDJur? Há quanto tempo?

Não utiliza

Menos de 1 mês

1 a 6 meses

7 a 12 meses

1 a 1 ano e meio

1 ano e meio a 2 anos

Mais de 2 anos 
4 - Você esta inscrito no serviço "Alertas por e-mail" (para ser notificado de novos depósitos da BDJur)?

Sim

Não

5 - Em caso de afirmativo, em quais coleções?

6 - Você é cadastrado na BDJur? Há quanto tempo?

Não é cadastrado

Menos de 1 mês

1 a 6 meses

7 a 12 meses

1 a 1 ano e meio

1 ano e meio a 2 anos

Mais de 2 anos

7 - Já fez contato com a equipe da BDJur? Foi atendido em sua solicitação?

Sim, e fui atendido em minha solicitação

Sim, porém não fui atendido.

Não fiz contato com a equipe da BDJur

8 - Como avalia o Layout da BDJur?

Ruim

Regular

Bom

Excelente

9 - Como avalia a Interface de pesquisa da BDJur?

Ruim

Regular

Bom

Excelente 
10 - Como avalia a organização das coleções da BDJur?

Ruim

Regular

Bom

Excelente

11 - Como avalia a qualidade do conteúdo da BDJur?

Ruim

Regular

Bom

Excelente

12 - Como avalia a Organização da ferramenta da BDJur?

Ruim

Regular

Bom

Excelente

13 - Como avalia a clareza dos objetivos das coleções da BDJur?

Ruim

Regular

Bom

Excelente

14 - Como avalia o resultado de pesquisa da BDJur?

Ruim

Regular

Bom

Excelente

15 - De uma maneira geral, que nota atribuiria à BDJur?

Ruim

Regular

Bom 


\section{Excelente}

Não tem opinião a respeito

16 - O que sugeriria para melhorar os serviços oferecidos pela BDJur? 
Anexo C

Segunda parte da pesquisa - freqüência de consulta das coleções

\section{Acervo Fotográfico do STJ}

Diariamente

Quinzenalmente

Mensalmente

Nunca

\section{Atos Normativos}

Diariamente

Quinzenalmente

Mensalmente

Nunca

Coletânea de Julgados e Momentos Jurídicos

Diariamente

Quinzenalmente

Mensalmente

Nunca

Documentos sobre a BDJur do STJ

Diariamente

Quinzenalmente

Mensalmente

Nunca

Documentos Administrativos do STJ

Diariamente

Quinzenalmente

Mensalmente

Nunca 
Diariamente

Quinzenalmente

Mensalmente

Nunca

Escola Nacional de Formação e Aperfeiçoamento de Magistrados - ENFAM

Diariamente

Quinzenalmente

Mensalmente

Nunca

\section{Eventos do STJ}

Diariamente

Quinzenalmente

Mensalmente

Nunca

Grupos de Pesquisa da CAPES

Diariamente

Quinzenalmente

Mensalmente

Nunca

Jurisprudência do STJ

Diariamente

Quinzenalmente

Mensalmente

Nunca

Laboratório de Conservação e Restauração de Documentos - LACOR

Diariamente

Quinzenalmente

Mensalmente

Nunca 


\section{Links Jurídicos}

Diariamente

Quinzenalmente

Mensalmente

Nunca

\section{Obras Raras}

Diariamente

Quinzenalmente

Mensalmente

Nunca

\section{Pesquisa Jurídicas}

Diariamente

Quinzenalmente

Mensalmente

Nunca

Produção Intelectual dos Ministros do STJ

Diariamente

Quinzenalmente

Mensalmente

Nunca

\section{Sumários Jurídicos}

Diariamente

Quinzenalmente

Mensalmente

Nunca

Tecnologia de BDJUR

Diariamente

Quinzenalmente

Mensalmente 
Nunca

Teses e Dissertações

Diariamente

Quinzenalmente

Mensalmente

Nunca

Trabalhos de Conclusões de Curso e Monografias

Diariamente

Quinzenalmente

Mensalmente

Nunca 